\title{
Simulating secondary organic aerosol in a regional air quality model using the statistical oxidation model - Part 3: Assessing the influence of semi-volatile and intermediate-volatility organic compounds and $\mathrm{NO}_{x}$
}

\author{
Ali Akherati ${ }^{1}$, Christopher D. Cappa ${ }^{2}$, Michael J. Kleeman ${ }^{2}$, Kenneth S. Docherty ${ }^{3}$, Jose L. Jimenez ${ }^{4}$, \\ Stephen M. Griffith ${ }^{5}$, Sebastien Dusanter ${ }^{6}$, Philip S. Stevens ${ }^{5}$, and Shantanu H. Jathar ${ }^{1}$ \\ ${ }^{1}$ Department of Mechanical Engineering, Colorado State University, Fort Collins, CO, USA \\ ${ }^{2}$ Department of Civil and Environmental Engineering, University of California Davis, Davis, CA, USA \\ ${ }^{3}$ Jacobs Technology, Raleigh, NC, USA \\ ${ }^{4}$ Department of Chemistry and Cooperative Institute for Research in Environmental Sciences (CIRES), \\ University of Colorado Boulder, Boulder, CO, USA \\ ${ }^{5}$ School of Public and Environmental Affairs and Department of Chemistry, Indiana University, Bloomington, IN, USA \\ ${ }^{6}$ IMT Lille Douai, Univ. Lille, SAGE - Département Sciences de l'Atmosphère et Génie de l'Environnement, \\ 59000 Lille, France
}

Correspondence: Shantanu H. Jathar (shantanu.jathar@ colostate.edu)

Received: 21 June 2018 - Discussion started: 10 July 2018

Revised: 26 February 2019 - Accepted: 27 February 2019 - Published: 8 April 2019

\begin{abstract}
Semi-volatile and intermediate-volatility organic compounds (SVOCs and IVOCs) from anthropogenic sources are likely to be important precursors of secondary organic aerosol (SOA) in urban airsheds, yet their treatment in most models is based on limited and obsolete data or completely missing. Additionally, gas-phase oxidation of organic precursors to form SOA is influenced by the presence of nitric oxide (NO), but this influence is poorly constrained in chemical transport models. In this work, we updated the organic aerosol model in the UCD/CIT (University of California at Davis/California Institute of Technology) chemical transport model to include (i) a semi-volatile and reactive treatment of primary organic aerosol (POA), (ii) emissions and SOA formation from IVOCs, (iii) the $\mathrm{NO}_{x}$ influence on SOA formation, and (iv) SOA parameterizations for SVOCs and IVOCs that are corrected for vapor wall loss artifacts during chamber experiments. All updates were implemented in the statistical oxidation model (SOM) that simulates the oxidation chemistry, thermodynamics, and gas-particle partitioning of organic aerosol (OA). Model treatment of POA, SVOCs, and IVOCs was based on an interpretation of a comprehensive set of source measurements available up to the
\end{abstract}

year 2016 and resolved broadly by source type. The $\mathrm{NO}_{x}$ influence on SOA formation was calculated offline based on measured and modeled VOC : $\mathrm{NO}_{x}$ ratios. Finally, the SOA formation from all organic precursors (including SVOCs and IVOCs) was modeled based on recently derived parameterizations that accounted for vapor wall loss artifacts in chamber experiments. The updated model was used to simulate a 2-week summer episode over southern California at a model resolution of $8 \mathrm{~km}$.

When combustion-related POA was treated as semivolatile, modeled POA mass concentrations were reduced by $15 \%-40 \%$ in the urban areas in southern California but were still too high when compared against "hydrocarbon-like organic aerosol" factor measurements made at Riverside, CA, during the Study of Organic Aerosols at Riverside (SOAR-1) campaign of 2005. Treating all POA (except that from marine sources) to be semi-volatile, similar to diesel exhaust POA, resulted in a larger reduction in POA mass concentrations and allowed for a better model-measurement comparison at Riverside, but this scenario is unlikely to be realistic since this assumes that POA from sources such as road and construction dust are semi-volatile too. Model predictions 
suggested that both SVOCs (evaporated POA vapors) and IVOCs did not contribute as much as other anthropogenic precursors (e.g., alkanes, aromatics) to SOA mass concentrations in the urban areas $(<5 \%$ and $<15 \%$ of the total SOA respectively) as the timescales for SOA production appeared to be shorter than the timescales for transport out of the urban airshed. Comparisons of modeled IVOC concentrations with measurements of anthropogenic SOA precursors in southern California seemed to imply that IVOC emissions were underpredicted in our updated model by a factor of 2. Correcting for the vapor wall loss artifact in chamber experiments enhanced SOA mass concentrations although the enhancement was precursor-dependent as well as $\mathrm{NO}_{x}$-dependent. Accounting for the influence of $\mathrm{NO}_{x}$ using the $\mathrm{VOC}: \mathrm{NO}_{x}$ ratios resulted in better predictions of OA mass concentrations in rural/remote environments but still underpredicted OA mass concentrations in urban environments. The updated model's performance against measurements combined with the results from the sensitivity simulations suggests that the OA mass concentrations in southern California are constrained within a factor of 2 . Finally, simulations performed for the year 2035 showed that, despite reductions in VOC and $\mathrm{NO}_{x}$ emissions in the future, SOA mass concentrations may be higher than in the year 2005, primarily from increased hydroxyl radical $(\mathrm{OH})$ concentrations due to lower ambient $\mathrm{NO}_{2}$ concentrations.

\section{Introduction}

Organic aerosol (OA) is an important yet uncertain component of atmospheric aerosol (Fuzzi et al., 2015; Jimenez et al., 2009) and has large impacts on air quality, climate, and human health (Pachauri et al., 2014). Combustion sources such as motor vehicles, biomass burning, and food cooking are significant contributors to atmospheric OA from urban to regional to global scales (Bond et al., 2004). Yet, in urban environments where combustion emissions are a dominant source, atmospheric models often underpredict total OA mass concentrations (e.g., Carlton et al., 2010). Models based on older parameterizations also predict much lower contributions of secondary organic aerosol (SOA) in urban areas (e.g., Volkamer et al., 2006; Jathar et al., 2017a) and may overemphasize the role of mobile sources (e.g., Ensberg et al., 2014), suggesting that combustion-related OA and other urban sources may not be well represented in models. There is a need to improve the treatment of combustion-related OA in atmospheric models since these improvements (i) will allow for better predictions of air quality that are needed to mitigate climate and health impacts from anthropogenic combustion sources and (ii) will facilitate improved understanding of additional potentially missing sources.

Research over the past decade has made major inroads in understanding the sources and properties of combustion- related OA (Gentner et al., 2017). Combustion sources directly emit organic particles (primary organic aerosol, POA) and also emit gaseous organic compounds that are oxidized in the atmosphere to form secondary organic aerosol. A significant fraction of the combustion-related POA mass is now understood to be semi-volatile - that is, material that exists in a dynamic equilibrium between the vapor and particle phases (Grieshop et al., 2009a, b; Huffman et al., 2009; Kuwayama et al., 2015; Lipsky and Robinson, 2006; May et al., 2013a, b, c; Robinson et al., 2007). This POA is formed as vapors in the combustion exhaust cool-down to become supersaturated and condense on existing seed aerosol (Robinson et al., 2010). After emission, some of this POA evaporates with atmospheric dilution since the aerosol mass available for partitioning decreases as the POA is transported away from source regions. Further, diurnal changes in temperature leading to changes in the vapor pressure can also cycle POA between the two phases. Both vapor and particle forms of semivolatile POA have been shown to photochemically react in the atmosphere to add or remove organic material from the particle phase (Miracolo et al., 2010) and become more oxygenated (Kroll et al., 2009), although the vapors react much faster. In addition, all combustion processes are now believed to include emissions of an important additional class of SOA precursors: intermediate-volatility organic compounds (IVOCs) (Jathar et al., 2014). Gas-chromatography massspectrometry applications have suggested that they are primarily composed of high-molecular-weight linear, branched, and cyclic alkanes (carbon numbers greater than 12) and aromatics (Gentner et al., 2012; Zhao et al., 2014, 2017). Model IVOCs have been shown to form SOA efficiently in chamber experiments (Chan et al., 2009; Lim and Ziemann, 2009; Presto et al., 2010; Tkacik et al., 2012) and have been hypothesized to account for a large fraction of the SOA formed from the photooxidation of motor vehicle exhaust and biomass burning emissions (Jathar et al., 2014; Zhao et al., 2017). The emissions and atmospheric properties (e.g., volatility, reactivity, SOA mass yields) of POA and IVOCs are known (or very likely) to vary by source (e.g., mobile sources versus biomass burning), and hence atmospheric models need to include a source-resolved treatment to accurately predict source contributions to OA and fine particulate matter.

Most commonly used chemical transport models (e.g., CMAQ, CAMx, PMCAMx, WRF-Chem, GEOS-Chem) have been updated to include a semi-volatile and reactive treatment of POA and emissions and SOA formation from IVOCs (Ahmadov et al., 2012; Koo et al., 2014; Murphy and Pandis, 2009; Pye and Seinfeld, 2010). However, their representation in models has been based on limited data and there are major differences between the implementations in different models. For example, in most models, with a few exceptions (e.g., most recent research version of the OA model in CMAQ developed by Koo et al., 2014), the gas-particle partitioning of POA was modeled based on measurements performed on a small off-road diesel engine from more than 
a decade ago (Robinson et al., 2007) and IVOC emissions were based on data gathered from two medium-duty diesel vehicles from two decades ago (Schauer et al., 1999). Models have assumed that these data are representative of emissions from modern diesel-powered sources and the POA and IVOC properties from diesel sources are similar to those from other sources. New source data are now available to update POA and IVOC emissions estimates in chemical transport models. Further, the most common schemes to model SOA formation from POA vapors and IVOCs use a single lumped precursor to simulate SOA formation from all sources (e.g., Pye and Seinfeld, 2010) or use an ad hoc aging routine that continuously reduces the volatility of the precursor oxidation products until they partition into the particle phase (Robinson et al., 2007). While some of these schemes have been validated against experimental data (Fountoukis et al., 2016; Hodzic and Jimenez, 2011; Murphy et al., 2017; Zhang et al., 2015), most have assumed that all sources have the same rate and potential to form SOA and, in some cases, ignore fragmentation reactions tied to multigenerational chemistry. Ad hoc aging schemes can overestimate net aerosol mass yields from an SOA precursor and can sometimes overpredict ambient SOA mass concentrations too, especially over larger regional scales (Dzepina et al., 2009, 2011; Hayes et al., 2015; Jathar et al., 2016). Recently, a host of studies have quantified the volatility of POA emissions from over 100 unique sources and measured SOA formation in more than 100 chamber experiments across six broad source classes: on- and off-road gasoline and diesel sources, wood stoves, and biomass burning (Gordon et al., 2014a, b; Hennigan et al., 2011; May et al., 2013a, b, c, 2014; Tkacik et al., 2017). These data offer a comprehensive set of measurements to inform and update the source-resolved semi-volatile and reactive behavior of POA and the emissions and SOA formation from IVOCs in atmospheric models.

SOA formation is strongly influenced by the presence of $\mathrm{NO}_{x}$ (Camredon et al., 2007; Chhabra et al., 2010; Loza et al., 2014; $\mathrm{Ng}$ et al., 2007b). For most SOA precursors, with the exception of alkanes (Loza et al., 2014) and certain sesquiterpenes ( $\mathrm{Ng}$ et al., 2007b), environmental chamber data suggest that the reaction chemistry at low- $\mathrm{NO}_{x}$, or more precisely low-NO, conditions $(<2 \mathrm{ppbv})$ produces more SOA than at high- $\mathrm{NO}_{x}$ conditions ( $>50 \mathrm{ppbv}$ and up to $\sim 1 \mathrm{ppmv}$ ) (Camredon et al., 2007; Chhabra et al., 2010; Loza et al., 2014; Ng et al., 2007; Zhang et al., 2014). The consensus seems to be that at low- $\mathrm{NO}_{x}$ conditions such as those found in remote continental or marine regions the peroxy radical $\left(\mathrm{RO}_{2}\right)$ - formed immediately after the reaction of the precursor with the oxidant - combines with the hydroperoxy radical $\left(\mathrm{HO}_{2}\right)$ or $\mathrm{RO}_{2}$ to form lower-volatility hydroperoxides or organic peroxides (Kroll and Seinfeld, 2008). LowNO conditions in remote regions, and in some cases in urban regions that have recently witnessed dramatic reductions in $\mathrm{NO}_{x}$ concentrations, can promote autooxidation reactions to form extremely low volatility organic compounds (Ehn et al.,
2014; Praske et al., 2018). At high- $\mathrm{NO}_{x}$, or more precisely high-NO, conditions such as those found in urban regions or biomass burning plumes, the $\mathrm{RO}_{2}$ reaction with $\mathrm{NO}$ either leads to the formation of alkoxy radicals that can then fragment the carbon backbone or to the formation of organic nitrates where both reactions result in more volatile products (Kroll and Seinfeld, 2008). Most atmospheric models (e.g., CMAQ, WRF-Chem, GEOS-Chem) have incorporated this knowledge to account for the influence of $\mathrm{NO}_{x}$ on the magnitude, composition, and spatial distribution of SOA.

In the mostly commonly used scheme (i.e., Henze et al., 2008), $\mathrm{RO}_{2}$ reacts with $\mathrm{HO}_{2}$ to form "low-NO" SOA or with $\mathrm{NO}$ to form "high-NO" SOA. The $\mathrm{HO}_{2}$ : NO ratio determines the branching ratio for $\mathrm{RO}_{2}$ and controls the SOA formed under varying $\mathrm{NO}_{x}$ levels. The SOA yields under the lowand high- $\mathrm{NO}_{x}$ conditions are parameterized based on chamber data gathered under low- and high- $\mathrm{NO}_{x}$ conditions respectively. Despite being widely implemented, this scheme has one key limitation that might tend to bias the $\mathrm{NO}_{x^{-}}$ dependent predictions of SOA. This scheme relies on an accurate prediction of $\mathrm{NO}$ and $\mathrm{HO}_{2}$ to determine the branching ratio for the $\mathrm{RO}_{2}$ radical. Although $\mathrm{NO}$ predictions can be validated against routine measurements and most chemical mechanisms seem to predict $\mathrm{NO}_{x}\left(\mathrm{NO}+\mathrm{NO}_{2}\right)$ within a factor of 2 , there are very few ambient data to validate model predictions of $\mathrm{HO}_{2}$. For example, as will be shown later, we find that predictions of $\mathrm{HO}_{2}$ concentrations from the use of a typical gas-phase chemical mechanism (SAPRC-11) in a 3-D model at Pasadena, CA, were almost an order of magnitude lower when compared against measurements at the same site in 2010 (Griffith et al., 2016). In this case, underpredicting $\mathrm{HO}_{2}$ concentrations by an order of magnitude could shift the scheme to produce most of the SOA via the high-NO pathway. In contrast, box models that have used the regional atmospheric chemistry mechanism (RACM) have shown good model-measurement comparisons for $\mathrm{HO}_{2}$ concentrations in polluted regions (Griffith et al., 2016; Hofzumahaus et al., 2009). Regardless, gas-phase chemical mechanisms that use the aforementioned scheme need to ensure accurate predictions of $\mathrm{HO}_{2}$ and $\mathrm{NO}$ concentrations to simulate the influence of $\mathrm{NO}_{x}$ on SOA formation.

In this work, we update the organic aerosol model in the UCD/CIT (University of California at Davis/California Institute of Technology) chemical transport model to include a semi-volatile and reactive treatment of POA, emissions and SOA formation from IVOCs, the $\mathrm{NO}_{x}$ influence on SOA formation, and SOA parameterizations for semi-volatile and intermediate-volatility organic compounds (SVOCs and IVOCs) that are corrected for vapor wall loss artifacts during chamber experiments. All of these updates are implemented in the statistical oxidation model (SOM) that simulates the oxidation chemistry, thermodynamics, and gas-particle partitioning of OA. Model inputs for POA and IVOCs are based on an interpretation of a comprehensive set of source measurements and resolved broadly by the source type. The $\mathrm{NO}_{x}$ 
influence on SOA formation is calculated offline based on measured and modeled VOC : $\mathrm{NO}_{x}$ ratios and $\mathrm{NO}_{x}$ concentrations. Finally, the SOA formation from SVOCs and IVOCs is modeled based on recently derived parameterizations that account for vapor wall loss artifacts in chamber experiments. Building on our earlier work (Cappa et al., 2016; Jathar et al., 2015, 2016), these updates within the framework of the SOM have improved the representation of OA in a chemical transport model.

To help the reader, we provide a brief overview of the different sections in this manuscript (section numbers in parentheses). Section 2 discusses details of the chemical transport model (2.1), organic aerosol model (2.2), simulations performed (2.3), and measurements used for model evaluation (2.4). In Sect. 3, we first describe the emissions (3.1), spatial distribution (3.2), and precursor contributions to $\mathrm{OA}$ (3.3), followed by the influence of vapor wall losses (3.4) and $\mathrm{NO}_{x}$ (3.6) on SOA formation. In the same section, we describe results from sensitivity simulations performed on the most sensitive inputs (3.5). Next, we compare model predictions of SOA precursors (4.1), OA (4.2), and POA and SOA (4.3) mass concentrations, and OA elemental composition (4.4) against measurements in southern California. Finally, we highlight key findings from this work in the summary and discussion Sect. 5.

\section{Methods}

\subsection{Chemical transport model}

We used the UCD/CIT regional chemical transport model (Kleeman and Cass, 2001) to simulate the emissions, transport, chemistry, and deposition of air pollutants over the state of California at a grid resolution of $24 \mathrm{~km}$ and over southern California (see Fig. S1 in the Supplement) using a nested $8 \mathrm{~km}$ grid from 20 July to 2 August 2005 . The results and analysis were focused on model predictions over southern California because the region, with approximately 15 million people, is home to one of the most polluted cities in the United States (Los Angeles; ALA, 2017). The time period for simulation was primarily chosen because the model has been previously evaluated for this time period (Jathar et al., 2016) and applied to examine important sources and formation pathways of OA (Cappa et al., 2016; Jathar et al., 2015, 2016, 2017b). The recent literature describes the latest version of the UCD/CIT model but we provide a very brief description of the models and inputs used in this work. Anthropogenic emissions for California were developed using the California Regional $\mathrm{PM}_{10} / \mathrm{PM}_{2.5}$ Air Quality Study (CRPAQS) inventory of 2000 but scaled to match conditions in 2005. Wildfire emissions were based on the model FINN (Fire Inventory from National Center for Atmospheric Research) (Wiedinmyer et al., 2011) although they were not found to significantly con- tribute to OA during the simulated time period (Docherty et al., 2011). Biogenic emissions were based on the model MEGAN (Model of Emissions of Gases and Aerosols from Nature) (Guenther et al., 2006). The Weather Research and Forecasting (WRF) v3.4 model (https://www.mmm. ucar.edu/weather-research-and-forecasting-model, last access: 25 March 2019) was used to produce hourly meteorological fields. National Centers for Environmental Prediction's (NCEP) NAM (North American Mesoscale) analysis data were used to set the initial and boundary conditions for WRF. The gas- and particle-phase initial and hourly varying boundary conditions were based on the results from the global model MOZART-4/NCEP (Emmons et al., 2010). The gas-phase chemistry was modeled using SAPRC-11 (Carter, 2010).

\subsection{Organic aerosol model}

\subsubsection{Statistical oxidation model (SOM)}

In this work, we use the statistical oxidation model developed by Cappa and Wilson (2012). The SOM is a semi-explicit and parameterizable model that simulates the oxidation chemistry, thermodynamics, and gas-particle partitioning of OA and its precursors. The SOM has been used to model SOA formation in chamber (Cappa et al., 2013; Cappa and Wilson, 2012; Zhang et al., 2014) and flow reactor (Eluri et al., 2018) experiments and was recently coupled with SAPRC-11 (gasphase chemical mechanism) in the UCD/CIT model (Jathar et al., 2015) to investigate the role of chamber-based vapor wall losses (Cappa et al., 2016) and multigenerational aging (Jathar et al., 2016) on the ambient SOA burden. In this work, we used an updated version of the SAPRC-SOM model embedded in the UCD/CIT model that included the POA and IVOC updates described in Sect. 2.2.2. A detailed description of the mathematical and numerical formulation of the SOM can be found in earlier literature but a brief description of the SOM framework follows. The SOM uses a two-dimensional carbon-oxygen grid to describe and track the evolution of the gas- and particle-phase organic carbon that is known to yield OA. Each grid cell in the SOM represents an organic species with the molecular formula $\mathrm{C}_{x} \mathrm{H}_{2 x+2-z} \mathrm{O}_{z}$, where $x=\mathrm{N}_{\mathrm{C}}$ and $z=\mathrm{N}_{\mathrm{O}}$. This species is expected to capture the average properties (e.g. volatility, reaction rate constants) of species with the same number of carbon $\left(\mathrm{N}_{\mathrm{C}}\right)$ and oxygen $\left(\mathrm{N}_{\mathrm{O}}\right)$ atoms that are formed from a given SOA precursor. Each species, in the gas and particle phases, is assumed to react with the hydroxyl radical $(\mathrm{OH})$. Operationally, $\mathrm{OH}$ is not consumed within the SOM as the chemistry captured in the SOM overlaps with that represented in the gas-phase mechanism (i.e., SAPRC-11). Reactions with the $\mathrm{OH}$ radical result in functionalization or fragmentation of the organic species and the distribution of the reaction products is tracked in the carbon-oxygen grid. Six precursor-specific adjustable parameters are assigned for each SOM grid: four parame- 
ters that define the molar yields of the four functionalized, oxidized products $\left(P_{\text {func }}\right)$; one parameter that determines the probability of functionalization or fragmentation $\left(m_{\text {frag }}\right)$; and one parameter that describes the relationship between $\mathrm{N}_{\mathrm{C}}$, $\mathrm{N}_{\mathrm{O}}$, and volatility $(\triangle \mathrm{LVP})$. In the model, the probability of fragmentation is modeled as a function of the $\mathrm{O}: \mathrm{C}$ ratio since species with higher $\mathrm{O}: \mathrm{C}$ ratios have been shown to fragment much more easily than species with lower $\mathrm{O}: \mathrm{C}$ ratios (Chacon-Madrid and Donahue, 2011). All SOM species properties (e.g., $\mathrm{OH}$ reactivity, volatility) are described in terms of $\mathrm{N}_{\mathrm{C}}$ and $\mathrm{N}_{\mathrm{O}}$.

Seven SOM grids were used to represent SOA formation from nine different precursor classes: (i) long alkanes, (ii) benzene, (iii) high-yield aromatics, (iv) low-yield aromatics, (v) isoprene, (vi) monoterpenes, (vii) sesquiterpenes, (viii) semi-volatile POA (SVOC), and (ix) IVOCs. Long alkanes as a precursor class include linear, branched, and cyclic alkanes roughly up to a carbon number of $\mathrm{C}_{13}$, and they represent speciated alkanes present in existing emissions inventories. These long alkanes are distinct from the alkanes that might be present in SVOCs and IVOCs. High-yield and lower-yield aromatics include all speciated aromatic compounds present in existing emissions inventories and, similar to the long alkanes precursor class, are distinct from the aromatics that might be present in SVOCs and IVOCs. Classes (i) through (vii) have been included in previous applications of the SOM and we refer the reader to our earlier publications for more details (Cappa et al., 2016; Jathar et al., 2015, 2016). Classes (viii) and (ix) were included in this work for the first time. The SOA formation from monoterpenes and sesquiterpenes (classes vi and vii) was modeled in the same SOM grid since both precursors used the SOM parameter sets for $\alpha$-pinene. Similarly, the SOA formation from SVOCs and IVOCs was modeled in the same SOM grid and both used the SOM parameter set for $n$-dodecane; sensitivity simulations were performed using the SOM parameter set for toluene. SOM parameters were determined from fitting the observed SOA volume produced in chamber experiments, with and without accounting for losses of vapors to the chamber walls. Details about how the vapor wall losses were modeled are described in Zhang et al. (2014) and Cappa et al. (2016). Briefly, loss of vapors to the Teflon walls of the chamber was modeled reversibly where the first-order uptake to the walls was assumed to be $2.5 \times 10^{-4} \mathrm{~s}^{-1}$ and the release of vapors from the walls was modeled using absorptive partitioning theory with the Teflon wall serving as an absorbing mass with an effective mass concentration of $10 \mathrm{mg} \mathrm{m}^{-3}$. Recent work has argued that vapor wall loss rates in Teflon chambers are much higher (larger than a factor of 5) than those used by Cappa et al. (2016) to derive the SOM parameterizations (Huang et al., 2018; Krechmer et al., 2016; Sunol et al., 2018). The use of a higher wall loss rate will tend to increase SOA aerosol mass yields further. This new understanding will need to be considered in the future.
We used low- and high- $\mathrm{NO}_{x}$-specific parameter sets to simulate SOA formation separately under low- and high$\mathrm{NO}_{x}$ conditions respectively since the current version of the SOM cannot account for continuous variation in $\mathrm{NO}_{x}$. The SOM parameters used for the nine different classes and seven different grids are listed in Table 1. Parameters for all species except for isoprene were from Cappa et al. (2016). The parameters for isoprene were from Hodzic et al. (2016), which included updates for the reactions rate constants for the first generation products from isoprene photooxidation. Jathar et al. (2016) investigated the influence of oligomerization reactions by allowing irreversible conversion of particle-phase SOM species into a single non-volatile species and found that the oligomerization pathway (as simulated) did not substantially affect the OA mass concentration in southern California. Hence, the oligomerization pathway was not considered in this work. We also did not include the formation of extremely low volatility organic compounds from oxidation of SOA precursors such as $\alpha$-pinene (Ehn et al., 2014) and alkanes (Praske et al., 2018) through autooxidation pathways, which will very likely be addressed in future versions of the SOM.

\subsubsection{Model inputs}

Semi-volatile and reactive POA (SVOC). POA from gasoline, diesel, biomass burning, and food cooking sources was treated as semi-volatile and reactive. POA from all other sources (e.g., marine, dust) was assumed to be non-volatile in all simulations except one where we explored the sensitivity in model predictions to this assumption (see Sect. 2.3 for more details). Semi-volatile POA was modeled by distributing POA emissions from the emissions inventory in the SOM grid as hydrocarbon species modeled as linear alkanes, i.e. as species with no oxygen (i.e., $\mathrm{C}_{x} \mathrm{H}_{z}$ ). The hydrocarbon/linear alkane distribution in the SOM grid was determined by refitting the volatility distributions published by May and coworkers (May et al., 2013a, b, c) such that the hydrocarbon distribution reproduced the observed gasparticle partitioning behavior; the hydrocarbon distributions are listed in Table S1 in the Supplement. We assumed all onand off-road gasoline exhaust POA to have the same hydrocarbon/linear alkane distribution as the volatility distribution determined by May et al. (2013a) from data for 51 lightduty gasoline vehicles. Almost three-quarters of the lightduty gasoline vehicles used in May et al. (2013a) were manufactured in or prior to 2005 (the year modeled in this work) and they did not find the POA volatility distribution data to be sensitive to the model year of the vehicle. Hence, the volatility distribution used in this work should still be representative of the vehicle fleet in 2005. Based on tests performed on eight light-duty gasoline vehicles, Kuwayama et al. (2015) found that the POA volatility for their vehicles was consistent with that determined by May et al. (2013a) for about half the vehicles but substantially lower for the other half. They hy- 
Table 1. SOA precursors and SOM parameters used in this work. VWL: vapor wall loss corrected; $\triangle$ LVP: change in vapor pressure linked to addition of one oxygen atom; $P_{\text {func }}$ : molar yields of species that add one to four oxygens per reaction $\left(P_{\mathrm{f}_{1}}\right.$ through $\left.P_{\mathrm{f}_{4}}\right) ; m_{\mathrm{frag}}$ : exponent influencing the probability of fragmentation.

\begin{tabular}{|c|c|c|c|c|c|c|c|c|c|c|c|}
\hline \multirow[t]{2}{*}{ SOA precursors } & \multirow{2}{*}{$\begin{array}{l}\text { SAPRC species/ } \\
\text { SOM grid }\end{array}$} & \multirow[t]{2}{*}{ SOM surrogate } & \multirow[t]{2}{*}{ VWL } & \multirow[t]{2}{*}{$\mathrm{NO}_{x}$} & \multirow[t]{2}{*}{$\Delta \mathrm{LVP}$} & \multicolumn{4}{|c|}{$P_{\text {func }}$} & \multirow[t]{2}{*}{$m_{\text {frag }}$} & \multirow[t]{2}{*}{ Reference } \\
\hline & & & & & & $P_{f_{1}}$ & $P_{f_{2}}$ & $P_{f_{3}}$ & $P_{f_{4}}$ & & \\
\hline \multirow[t]{2}{*}{ SVOC/IVOC } & \multirow[t]{2}{*}{$\mathrm{POA}+\mathrm{IVOC}$} & \multirow{4}{*}{$\begin{array}{l}n \text {-Dodecane/ } \\
\text { toluene }\end{array}$} & No & Low & 1.54 & 0.717 & 0.278 & 0.0028 & 0.0022 & 0.122 & Loza et al. (2014) \\
\hline & & & & High & 1.39 & 0.927 & 0.0101 & 0.018 & 0.0445 & 0.098 & \\
\hline \multirow{2}{*}{ Alkanes } & \multirow{2}{*}{ ALK } & & Yes & Low & 1.83 & 0.999 & 0.001 & 0.001 & 0.001 & 2 & \\
\hline & & & & High & 1.47 & 0.965 & 0.001 & 0.002 & 0.032 & 0.266 & \\
\hline \multirow[t]{4}{*}{ Benzene } & \multirow[t]{4}{*}{ BENZ } & \multirow[t]{4}{*}{ Benzene } & No & Low & 2.01 & 0.769 & 0.001 & 0.0505 & 0.180 & 0.0593 & Ng et al. (2007a) \\
\hline & & & & High & 1.7 & 0.079 & 0.001 & 0.919 & 0.001 & 0.535 & \\
\hline & & & Yes & Low & 1.97 & 0.637 & 0.001 & 0.002 & 0.360 & 0.0807 & \\
\hline & & & & High & 1.53 & 0.008 & 0.001 & 0.991 & 0.001 & 0.824 & \\
\hline \multirow{4}{*}{$\begin{array}{l}\text { High-yield } \\
\text { aromatics }\end{array}$} & \multirow{4}{*}{ ARO1 } & \multirow[t]{4}{*}{ Toluene } & No & Low & 1.84 & 0.561 & 0.001 & 0.001 & 0.438 & 0.010 & Zhang et al. (2014) \\
\hline & & & & High & 1.24 & 0.003 & 0.001 & 0.001 & 1.010 & 0.222 & \\
\hline & & & Yes & Low & 1.77 & 0.185 & 0.001 & 0.002 & 0.812 & 1.31 & \\
\hline & & & & High & 1.42 & 0.856 & 0.001 & 0.002 & 0.141 & 4.61 & \\
\hline \multirow{4}{*}{$\begin{array}{l}\text { Low-yield } \\
\text { aromatics }\end{array}$} & \multirow[t]{4}{*}{$\mathrm{ARO} 2$} & \multirow[t]{4}{*}{$m$-Xylene } & No & Low & 1.76 & 0.735 & 0.001 & 0.002 & 0.262 & 0.010 & Ng et al. (2007a) \\
\hline & & & & High & 1.68 & 0.936 & 0.001 & 0.002 & 0.061 & 0.010 & \\
\hline & & & Yes & Low & 2.05 & 0.102 & 0.001 & 0.878 & 0.019 & 1.08 & \\
\hline & & & & High & 1.46 & 0.001 & 0.001 & 0.942 & 0.056 & 0.0671 & \\
\hline \multirow[t]{4}{*}{ Isoprene } & \multirow[t]{4}{*}{ ISOP } & \multirow[t]{4}{*}{ Isoprene } & No & Low & 2.26 & 0.973 & 0.001 & 0.001 & 0.026 & 0.010 & \multirow{4}{*}{$\begin{array}{l}\text { Chhabra et al. (2011); } \\
\text { Hodzic et al. (2016) }\end{array}$} \\
\hline & & & & High & 1.94 & 0.952 & 0.001 & 0.030 & 0.016 & 0.063 & \\
\hline & & & Yes & Low & 2.25 & 0.1646 & 0.5164 & 0.3012 & 0.0179 & 0.0244 & \\
\hline & & & & High & 1.93 & 0.988 & 0.0002 & 0.0116 & 0.0009 & 0.51 & \\
\hline \multirow{4}{*}{$\begin{array}{l}\text { Monoterpenes/ } \\
\text { sesquiterpenes }\end{array}$} & \multirow[t]{4}{*}{ TRP } & \multirow[t]{4}{*}{$\alpha$-Pinene } & No & Low & 1.87 & 0.001 & 0.869 & 0.078 & 0.053 & 0.010 & Chhabra et al. (2011) \\
\hline & & & & High & 1.62 & 0.068 & 0.633 & 0.275 & 0.024 & 0.035 & \\
\hline & & & Yes & Low & 1.97 & 0.419 & 0.426 & 0.140 & 0.014 & 0.305 & \\
\hline & & & & High & 1.91 & 0.500 & 0.422 & 0.070 & 0.008 & 0.16 & \\
\hline
\end{tabular}

pothesized that the lower POA volatility could be attributed to fuel oxidation products. The findings of Kuwayama et al. (2015) suggest that the volatility distribution used in this work may overestimate the evaporation of POA with dilution. We assumed all on- and off-road diesel exhaust POA to have the same hydrocarbon/linear alkane distribution as the volatility distribution determined by May et al. (2013b) from data for two medium-duty diesel trucks, three heavyduty diesel trucks, and a single off-road diesel engine. May et al. (2013b) did not report on differences in the POA volatility distribution between vehicles that did or did not use a modern emissions control system (diesel particulate filter, DPF; and/or diesel oxidation catalyst, DOC). Hence, we assumed that the volatility distribution used here was still representative of the mostly non-DPF and non-DOC vehicle fleet in 2005. We assumed residential wood combustion and wildfires to have the same hydrocarbon/linear alkane distribution as the volatility distribution determined by May et al. (2013c) from a selection of 15 different fuels. We assumed food cooking to have the same hydrocarbon/linear alkane distribution as that for wildfires. Recent work suggests that food cooking OA may be significantly less volatile than wildfire OA (Louvaris et al., 2017; Woody et al., 2016). To examine the influ- ence of this finding, we performed sensitivity simulations to model the POA from food cooking sources using the volatility distribution of Louvaris et al. (2017). This work, similar to the most recent implementation in the Community Multiscale Air Quality (CMAQ) model (Koo et al., 2014; Woody et al., 2016), included a source-resolved treatment of semivolatile POA that was tied to a comprehensive set of source measurements.

The reactive behavior of POA was modeled by assuming that the POA vapors (i.e. SVOCs) (represented as a hydrocarbon distribution) and their products participated in gasphase oxidation and formed SOA similar to linear alkanes and utilized the SOM parameter set for $n$-dodecane. The surrogate, in this case $n$-dodecane, only informs the multigenerational oxidation chemistry of the precursor, and the actual compound of interest (e.g., a $\mathrm{C}_{15}$ linear alkane) can have a different SOA mass yield than that of $n$-dodecane. The reaction rate constants with $\mathrm{OH}$ for the parent hydrocarbons were assumed to be similar to the carbon-equivalent linear alkane. We should note that the presence of branched and cyclic alkanes and aromatic compounds in the SVOCs would require the use of a higher reaction rate constant with $\mathrm{OH}$ as these compounds are more reactive with $\mathrm{OH}$ than carbon- 
equivalent linear alkanes. The equivalence to linear alkanes while not perfect was probably a good assumption for gasoline and diesel sources since alkanes account for a substantial fraction of gasoline and diesel fuel (Gentner et al., 2012) and lubricating oil (Caravaggio et al., 2007) and are a dominant organic class in both gas- and particle-phase emissions from mobile sources (Brandenberger et al., 2005; Hays et al., 2017; Schauer et al., 1999, 2002b)(Worton et al., 2014). However, alkanes do not make up a significant fraction of the gas- and particle-phase emissions from biomass burning (Hatch et al., 2015; Schauer et al., 2001; Stockwell et al., 2015) or food cooking (Schauer et al., 2002a), and hence it is unlikely that linear alkanes are good surrogates to model the oxidation of SVOCs from these sources. To test the sensitivity of the model predictions to the surrogate used to model SOA formation from SVOCs, we ran sensitivity simulations where we modeled the SVOCs as a mixture of aromatic compounds using the SOM parameter set for toluene (see rationale in Sect. 2.4).

Intermediate-volatility organic compounds. We included IVOC emissions from gasoline, diesel, and biomass burning. We assumed none of the other sources emitted IVOCs for all simulations except one where we explored the sensitivity in model predictions to this assumption (see Sect. 2.4 for more details). The IVOC emissions estimates and their potential to form SOA was based on the work of Jathar et al. (2014). In Jathar et al. (2014), IVOC emissions, defined as the sum of all unspeciated compounds, were determined as a mass fraction of the total non-methane organic gas (NMOG) emissions for three different source categories: gasoline vehicles, diesel vehicles, and biomass burning. Here, the IVOCs, as unspeciated organic compounds, are new SOA precursors added to the emissions inventory and regardless of their chemical makeup are distinct from the speciated precursors such as long alkanes and aromatics already present in existing emissions inventories. IVOCs were assumed to be $25 \%$ of the NMOG emissions for on- and off-road gasoline exhaust, $20 \%$ of the NMOG emissions for on- and off-road diesel exhaust, and $7 \%$ of the NMOG emissions for residential wood combustion and wildfires. The IVOC: NMOG fractions did not appear to be statistically different for the gasoline and diesel sources manufactured before or after 2005, and hence those fractions were assumed to be representative of the source fleet in 2005. No IVOCs were considered for the food cooking source but recent work suggests that they might play a role in influencing the OA evolution from a multitude of food cooking sources (Kaltsonoudis et al., 2017; Liu et al., 2017). We assumed that the NMOG emissions in the emissions inventory accounted for most of the gas-phase organic compound mass that included the IVOCs, and hence the addition of IVOC emissions meant that the non-IVOC emissions had to be reduced to conserve total NMOG mass. Recent literature suggests that IVOCs could be lost to walls of the sampling hardware (e.g., tubing, bags) (Pagonis et al., 2017) and therefore would be excluded in the NMOG mea- surement. Our assumption should result in conservative estimates for the influence of IVOC emissions on SOA formation.

Following Jathar et al. (2014), the IVOCs were modeled as a $\mathrm{C}_{13}$ hydrocarbon for those from on- and off-road gasoline sources and as a $\mathrm{C}_{15}$ hydrocarbon for those from onand off-road diesel sources and biomass burning. The oxidation of the IVOC hydrocarbons and their reaction products and the subsequent SOA formation were modeled assuming equivalence to a linear alkane and using the SOM parameter set for $n$-dodecane. As mentioned earlier, $n$-dodecane only informs the multigenerational oxidation chemistry of the precursor, and the actual compound of interest (e.g., a $\mathrm{C}_{13}$ or $\mathrm{C}_{15}$ linear alkane) can have a different SOA mass yield than that of $n$-dodecane. The equivalent linear alkane to model SOA formation from IVOCs in Jathar et al. (2014) was based on fitting the SOA formation observed in chamber experiments (Gordon et al., 2014a, b; Hennigan et al., 2011), and hence the choice of the hydrocarbon in this work was experimentally constrained. Jathar et al. (2014) used linear alkanes as a surrogate as the SOA formation from linear alkanes was well studied when they developed the parameterization and the SOA mass yields increased predictably with the carbon number of the precursor. Recent application of gas-chromatography mass spectrometry to combustion emissions has found that IVOCs are mostly composed of branched and cyclic alkanes and aromatic compounds (Gentner et al., 2012; Koss et al., 2018; Zhao et al., 2016, 2017). So while it would have been more appropriate to model the IVOCs as an alkane-aromatic mixture, this choice would not have substantially changed the model predictions in the work as the SOA formation from this alkane-aromatic mixture would still be constrained to the same chamber experiments. We will consider the recent detailed speciation work surrounding IVOCs in future applications of this model. In this work, we also investigated the sensitivity in model predictions to the use of an aromatic compound (i.e., toluene) as a surrogate instead of an alkane (i.e., $n$-dodecane) to model SOA formation from IVOCs (see rationale in Sect. 2.4).

Recently, Zhao and coworkers (Zhao et al., 2015, 2016) used thermal-desorption gas-chromatography mass spectrometry (TD-GC-MS) to measure IVOC emissions in gasoline and diesel exhaust and speciated/classified the IVOCs as a mixture of linear, branched, and cyclic compounds resolved by carbon number. We should note that Zhao et al. $(2015,2016)$ defined IVOCs as the sum of speciated and unspeciated hydrocarbons roughly larger than a $\mathrm{C}_{12}$ alkane, which was different from the definition adopted by Jathar et al. (2014). In their first paper, Zhao et al. (2015) found IVOCs to be about $60 \%$ of the NMOG mass emissions for tailpipe exhaust from older diesel vehicles/engines (ones without particle filters or oxidation/reduction catalysts). In this work we used an IVOC : NMOG ratio of 0.2 and likely underestimated IVOC emissions from diesel sources by a factor of 2.5. Zhao et al. (2015) concluded that the effective IVOC 
yield based on their speciation was comparable to the yield of the $\mathrm{C}_{15}$ linear alkane used in this work, but the application of that yield overpredicted the chamber SOA data from Gordon et al. (2014a) by a factor of 1.8 ; virtually all of the SOA predicted by Zhao et al. (2016) was from the oxidation of IVOCs. If one assumed that the effects from lower IVOC emissions (factor of 2.5) were roughly balanced by the use of higher SOA yields (factor of 1.8), then the SOA formation from diesel sources was probably well represented in our work.

In their second paper, Zhao et al. (2016) found the IVOCs to be only about $4 \%$ of the NMOG mass emissions in gasoline exhaust but we used an IVOC : NMOG ratio of 0.25 in this work. This suggests that we may be overestimating the gasoline exhaust IVOC emissions by approximately a factor of 6 in this work. Based on the speciation performed, Zhao et al. (2016) estimated that the IVOCs collectively had an SOA yield between $19 \%$ and $24 \%$ at an OA mass concentration of $9 \mu \mathrm{g} \mathrm{m}^{-3}(9 \mu \mathrm{g} \mathrm{m})^{-3}$ was the average endof-experiment concentration in the chamber experiments of Gordon et al., 2014a), which was slightly more than twice the SOA yield for a $\mathrm{C}_{13}$ linear alkane $(7 \%-12 \%)$ - used to model gasoline IVOCs in this work - at the same OA mass concentration. However, application of the Zhao et al. (2016) SOA yields for IVOCs underpredicted the observed chamber SOA formation for newer gasoline vehicles by a factor of $\sim 2$. Since IVOC oxidation accounted for slightly less than half of the SOA formed (with the other half coming from single-ring aromatics), the IVOC SOA yields in Zhao et al. (2016) would need to be tripled to explain the chamber SOA measurements. If we assumed that the effects from higher IVOC emissions (factor of 6) were approximately balanced by the use of lower SOA yields (factor of $2 \times 3=6$ ), then the SOA formation from gasoline sources in this work was probably well represented in our work. To summarize, the IVOC emissions estimates and the surrogates used to model SOA formation from IVOCs from gasoline and diesel sources in this work, while different from those suggested in Zhao et al. $(2015,2016)$, are still consistent with the SOA measurements made by Gordon et al. (2014a, b). In a future version of the model, we will aim to include the IVOC emissions estimates of Zhao et al. $(2015,2016)$ and update the SOA parameterizations accordingly. It is likely that these might slightly alter the spatiotemporal distribution of IVOC SOA in the modeled domain.

\subsubsection{Modeling the $\mathrm{NO}_{x}$ dependence on SOA formation}

Previous applications of the SOM have simulated SOA under low- and high- $\mathrm{NO}_{x}$ conditions separately since the SOM, in its current form, cannot model the continuous evolution of SOA under varying $\mathrm{NO}_{x}$ conditions using the local $\mathrm{NO} / \mathrm{HO}_{2}$. Predictions from either of these simulations (Jathar et al., 2016) or the average of these simulations (Cappa et al., 2016) likely do not accurately characterize the evolution or spatial distribution of SOA since $\mathrm{NO}_{x}$ concentrations exhibit strong spatial variability with higher concentrations in urban (e.g., traffic) and source (e.g., wildfires) regions. For example, since most precursors have higher SOA yields under low- $\mathrm{NO}_{x}$ conditions than under high- $\mathrm{NO}_{x}$ conditions, the use of an average is expected to overestimate $\mathrm{SOA}$ in high- $\mathrm{NO}_{x}$ urban areas and underestimate SOA in low- $\mathrm{NO}_{x}$ rural/remote continental areas.

In this work, we used two different offline techniques to account for the influence of $\mathrm{NO}_{x}$ on SOA formation. For both methods, we assumed that the 3-D model predictions based on the low- and high-NO $\mathrm{NO}_{x} \mathrm{SOA}$ parameterizations bounded the minimum and maximum ambient SOA mass concentrations. Xu et al. (2015) found that the SOA formation from isoprene photooxidation was maximized at intermediate $\mathrm{NO}_{x}$ levels with lower values at the extreme $\mathrm{NO}_{x}$ levels, suggesting that our bounding assumption may not necessarily hold for all precursor species. Presto and Donahue (2006) found that the SOA from $\alpha$-pinene ozonolysis under varying $\mathrm{NO}_{x}$ conditions could be estimated by interpolating the SOA formed between the low- and high- $\mathrm{NO}_{x}$ conditions using the VOC : $\mathrm{NO}_{x}$ ratio. Hence, in the first method, we used the VOC : $\mathrm{NO}_{x}$ ratios from the low- and high- $\mathrm{NO}_{x}$ chamber experiments as our bounds and used the 3-D-model-predicted VOC : $\mathrm{NO}_{x}$ ratio to interpolate between the minimum and maximum SOA mass concentrations predicted from the lowand high- $\mathrm{NO}_{x}$ simulations. Previous work (e.g., Camredon et al., 2007; Xu et al., 2015) has also found SOA formation to vary along a $\mathrm{NO}_{x}$ scale, and hence, in the second method, we used $\mathrm{NO}_{x}$ concentrations from the low- and high- $\mathrm{NO}_{x}$ chamber experiments and the 3-D model predictions to perform the interpolation. For each method, we performed the interpolation on the SOA mass concentrations assuming a linear or logarithmic dependence on the VOC : $\mathrm{NO}_{x}$ ratios and $\mathrm{NO}_{x}$ concentrations. The linear dependency was chosen for simplicity while the logarithmic dependency was chosen to mimic the visual trends in SOA and VOC: $\mathrm{NO}_{x}$ or $\mathrm{NO}_{x}$ reported in previous work and also to produce the highest response in the SOA formation with $\mathrm{NO}_{x}$. The VOC: $\mathrm{NO}_{x}$ ratio and the $\mathrm{NO}_{x}$ concentration served as an approximate surrogate for the $\mathrm{HO}_{2}$ : $\mathrm{NO}$ ratio used in most atmospheric models to simulate the $\mathrm{NO}_{x}$-dependent SOA formation. The $\mathrm{NO}_{x}$-adjusted SOA concentrations ( $\left.\mathrm{SOA}_{\text {eff }}\right)$ from each precursor at each grid cell were calculated from model predictions from the low- and high- $\mathrm{NO}_{x}$ simulations using the following equations:

$$
\begin{aligned}
& \mathrm{SOA}_{\text {eff }}=\mathrm{SOA}_{\text {high } \mathrm{NO}_{x}} \\
& +\frac{\mathrm{SOA}_{\text {low NO}}-\mathrm{SOA}_{\text {high NO}}}{\left(\mathrm{VOC}: \mathrm{NO}_{x}\right)_{\text {low NO}}-\left(\mathrm{VOC}: \mathrm{NO}_{x}\right)_{\text {high NO}}} \\
& \times\left(\left(\mathrm{VOC}: \mathrm{NO}_{x}\right)_{\text {model }}-\left(\mathrm{VOC}: \mathrm{NO}_{x}\right)_{\text {high } \mathrm{NO}_{x}}\right),
\end{aligned}
$$




$$
\begin{aligned}
& \mathrm{SOA}_{\text {eff }}=\mathrm{SOA}_{\text {high } \mathrm{NO}_{x}} \\
& +\frac{\mathrm{SOA}_{\text {low NO}}-\mathrm{SOA}_{\text {high NO}}}{\log \left(\mathrm{VOC}: \mathrm{NO}_{x}\right)_{\text {low NO}}-\log \left(\mathrm{VOC}: \mathrm{NO}_{x}\right)_{\text {high NO}}} \\
& \quad \times\left(\log \left(\mathrm{VOC}: \mathrm{NO}_{x}\right)_{\text {model }}-\log \left(\mathrm{VOC}: \mathrm{NO}_{x}\right)_{\text {high } \mathrm{NO}_{x}}\right),
\end{aligned}
$$

$$
\begin{aligned}
& \mathrm{SOA}_{\text {eff }}=\mathrm{SOA}_{\text {low NO}} \\
& -\frac{\mathrm{SOA}_{\text {low NO }_{x}}-\mathrm{SOA}_{\text {high NO}}}{\left(\mathrm{NO}_{x}\right)_{\text {high NO}}-\left(\mathrm{NO}_{x}\right)_{\text {low NO}}} \\
& \quad \times\left(\left(\mathrm{NO}_{x}\right)_{\text {model }}-\left(\mathrm{NO}_{x}\right)_{\text {low NO}}\right), \\
& \mathrm{SOA}_{\text {eff }}=\mathrm{SOA}_{\text {low NO}} \\
& -\frac{\mathrm{SOA}_{\text {low NO}}-\mathrm{SOA}_{\text {high NO}}}{\log \left(\mathrm{NO}_{x}\right)_{\text {high NO}}-\log \left(\mathrm{NO}_{x}\right)_{\text {low } \mathrm{NO}_{x}}} \\
& \quad \times\left(\log \left(\mathrm{NO}_{x}\right)_{\text {model }}-\log \left(\mathrm{NO}_{x}\right)_{\text {low } \mathrm{NO}_{x}}\right),
\end{aligned}
$$

where $\mathrm{SOA}_{\text {low } \mathrm{NO}_{x}}$ and $\mathrm{SOA}_{\text {high } \mathrm{NO}_{x}}$ are model predictions of SOA from using the low- and high- $\mathrm{NO}_{x}$ parameterizations respectively, $\left(\mathrm{VOC}: \mathrm{NO}_{x}\right)_{\text {low }} \mathrm{NO}_{x}$ and $\left(\mathrm{VOC}: \mathrm{NO}_{x}\right)_{\text {high }} \mathrm{NO}_{x}$ are the initial VOC: $\mathrm{NO}_{x}$ ratios from the chamber experiments used to develop the low- and high- $\mathrm{NO}_{x} \mathrm{SOA}$ parameterizations, $\left(\mathrm{VOC}: \mathrm{NO}_{x}\right)_{\text {model }}$ is the model-predicted VOC : $\mathrm{NO}_{x}$ ratio in the model grid cell, $\left(\mathrm{NO}_{x}\right)_{\text {low }} \mathrm{NO}_{x}$ and $\left(\mathrm{NO}_{x}\right)_{\text {high }} \mathrm{NO}_{x}$ are the $\mathrm{NO}_{x}$ concentrations from the chamber experiments used to develop the low- and high- $\mathrm{NO}_{x}$ parameterizations, and $\left(\mathrm{NO}_{x}\right)_{\text {model }}$ is the model-predicted $\mathrm{NO}_{x}$ concentration in the model grid cell. Equations (1) and (3) assume linear dependence while Eqs. (2) and (4) assume logarithmic dependence. For the $\left(\mathrm{VOC}: \mathrm{NO}_{x}\right)_{\text {model }}$ ratio, the VOC is the sum of all organic species tracked in the SAPRC-11 gas-phase chemical mechanism, including all IVOCs and gas-phase SVOCs. $\mathrm{NO}_{x}$ is the sum of $\mathrm{NO}$ and $\mathrm{NO}_{2}$. The VOC: $\mathrm{NO}_{x}$ ratios and the $\mathrm{NO}_{x}$ concentrations from the chamber experiments used in the equations were gathered directly from the primary references and are listed in Table 2. When the (VOC: $\left.\mathrm{NO}_{x}\right)_{\text {model }}$ or $\left(\mathrm{NO}_{x}\right)_{\text {model }}$ values were lower or higher than the chamber values in Table 2, the SOA formation was set to model predictions from the bounding simulations.

We acknowledge that this approach to modeling the $\mathrm{NO}_{x}$ influence on SOA formation is limited and is sensitive to the following assumptions: (i) the $\mathrm{VOC}: \mathrm{NO}_{x}$ ratio plus $\mathrm{NO}_{x}$ concentration is a good proxy to model the $\mathrm{HO}_{2}: \mathrm{NO}$ ratio and the branching between low- and high- $\mathrm{NO}_{x} \mathrm{SOA}$ formation; (ii) the low- and high- $\mathrm{NO}_{x}$ chamber experiments for a particular precursor bound the minimum and maximum SOA formed; (iii) the SOA response between the low and high $\mathrm{NO}_{x}$ levels varies linearly or logarithmically with VOC: $\mathrm{NO}_{x}$ ratios and $\mathrm{NO}_{x}$ concentrations; and (iv) the modelpredicted VOC concentrations at each grid cell, summed across a mixture of organic compounds, are analogous to the initial VOC concentrations from the chamber experiment to calculate VOC : $\mathrm{NO}_{x}$ ratios. There are few experimental data to test these assumptions and these need to be investigated in future work. In addition to modeling the influence of $\mathrm{NO}_{x}$ on ambient SOA concentrations, this approach allowed us to explore the influence of reductions in $\mathrm{NO}_{x}$ emissions and concentrations on ambient $\mathrm{OA}$ concentrations in the future.

\subsection{Simulations}

The Base simulation - representing our most comprehensive simulation - included the updates described in Sect. 2.2.2: a source-resolved semi-volatile and reactive treatment of POA, source-resolved SOA formation from SVOCs and IVOCs, and correction of the subsequent SOA formation for vapor wall losses in chambers. The Base simulation included subsimulations at two resolutions ( 24 and $8 \mathrm{~km}$ ) with two $\mathrm{NO}_{x}$ parameterizations (low and high $\mathrm{NO}_{x}$ ).

Additional simulations were designed and performed with two objectives in mind: (i) to examine the influence of each update included in this work and (ii) to test the sensitivity in model predictions to uncertainties inherent in the updates and other model inputs. A set of four simulations was performed to systematically study the influence of model updates. These included the following simulations where only one update was made over the previous configuration: (1) Traditional - non-volatile POA, no IVOCs, SOA from VOCs, and no correction for chamber vapor wall losses; (2) SVOC - semivolatile POA, no IVOCs, SOA from SVOCs and VOCs, and no correction for chamber vapor wall losses; (3) IVOC semi-volatile POA; IVOCs; SOA from SVOCs, IVOCs, and VOCs; and no correction for chamber vapor wall losses; and (4) Base - semi-volatile POA; IVOCs; SOA from SVOCs, IVOCs, and VOCs; and correction for chamber vapor wall losses. Successive differences in model predictions between the Traditional, SVOC, IVOC, and Base simulations were used to systematically examine the influence of the semivolatile and reactive POA, IVOCs, and chamber vapor wall losses respectively.

A set of six simulations were performed to study uncertainties in model inputs. The $\mathrm{SVOC}_{\max }$ (5) simulation assumed that POA from all sources (all POA except marine POA) was semi-volatile and modeled using the volatility distribution for diesel exhaust POA. Diesel POA was chosen since it was the most volatile of the volatility distributions used in this work. This simulation bounded the maximum loss in POA mass to evaporation. The $\mathrm{IVOC}_{\max }$ (6) simulation assumed that all sources (combustion and noncombustion except biogenic sources) emitted IVOCs, which were estimated using an IVOC:NMOG ratio of 0.2 and allowed to form SOA equivalent to a $\mathrm{C}_{15}$ alkane. This simulation provided an upper-bound estimate to the contribution of IVOCs to ambient SOA although the IVOC emissions and their potential to form SOA could be even higher than that assumed here. The No Aging (7) simulation assumed no multigenerational aging or, in other words, the emitted precursor was allowed to react with $\mathrm{OH}$ and form four func- 
Table 2. Low and high $\mathrm{VOC}: \mathrm{NO}_{x}$ ratios in $\mathrm{ppb} \mathrm{ppb}^{-1}$ and $\mathrm{NO}_{\mathrm{x}}$ concentrations in ppbv from chamber experiments used to model the influence of $\mathrm{NO}_{\mathrm{x}}$ on $\mathrm{SOA}$ formation.

\begin{tabular}{llllrl}
\hline SOM surrogate & $\left(\mathrm{VOC}: \mathrm{NO}_{x}\right)_{\text {low } \mathrm{NO}_{x}}$ & $\left(\mathrm{NO}_{x}\right)_{\text {low } \mathrm{NO}_{x}}$ & $\left(\mathrm{VOC}: \mathrm{NO}_{x}\right)_{\text {high NO}}$ & $\left(\mathrm{NO}_{x}\right)_{\text {high }} \mathrm{NO}_{x}$ & Reference \\
\hline$n$-Dodecane & $17.0^{\mathrm{a}}$ & $<2$ & 0.09 & 343 & Loza et al. (2014) \\
Benzene & $207^{\mathrm{a}}$ & $<2$ & 1.98 & 169 & Ng et al. (2007a) \\
Toluene & $46.3^{\mathrm{a}, \mathrm{b}}$ & $<0.8$ & $0.76^{\mathrm{b}}$ & 50 & Zhang et al. (2014) \\
$m$-Xylene & $12.1^{\mathrm{a}, \mathrm{c}}$ & $<2$ & 0.10 & 943 & Ng et al. (2007a) \\
Isoprene & $24.5^{\mathrm{a}}$ & $<2$ & 0.29 & 937 & Chhabra et al. (2010) \\
$\alpha$-Pinene & $33.1^{\mathrm{a}}$ & $<2$ & 0.05 & 844 & Chhabra et al. (2010) \\
\hline
\end{tabular}

a Minimum VOC : $\mathrm{NO}_{x}$ ratios since these assume a $\mathrm{NO}_{x}$ concentration of 0.8 ppbv in the chamber. ${ }^{\mathrm{b}}$ Average of six experiments performed by Zhang et al. (2014)

${ }^{\mathrm{c}}$ Average of two experiments performed by $\mathrm{Ng}$ et al. (2007a).

Table 3. Names and descriptions of the simulations performed in this work.

\begin{tabular}{|c|c|c|c|c|c|}
\hline No. & Name & $\begin{array}{l}\text { Semi-volatile \& } \\
\text { reactive POA } \\
(\mathrm{SVOC})\end{array}$ & IVOC & $\begin{array}{l}\text { Vapor wall } \\
\text { losses for SVOC, } \\
\text { IVOC, and VOC }\end{array}$ & Additional details \\
\hline 1 & Traditional & No & No & No & Same as model of Cappa et al. (2016) \\
\hline 2 & SVOC & Yes $^{b}$ & No & No & - \\
\hline 3 & IVOC & $\mathrm{Yes}^{\mathrm{b}}$ & Yes & No & - \\
\hline 4 & Base & Yes $^{b}$ & Yes & Yes & Base case model used in this work \\
\hline 5 & $\mathrm{SVOC}_{\max }{ }^{\mathrm{a}}$ & Yes $^{b}$ & Yes & Yes & SVOCs modeled as per diesel parameterization \\
\hline 6 & IVOC $_{\max }{ }^{a}$ & Yes $^{b}$ & Yes & Yes & IVOCs modeled as per diesel parameterization \\
\hline 7 & No Aging ${ }^{\mathrm{a}}$ & $\mathrm{Yes}^{\mathrm{b}}$ & Yes & Yes & No multigenerational aging \\
\hline 8 & $\mathrm{VOC}_{\text {spec }^{\mathrm{a}}}{ }^{\mathrm{a}}$ & $\mathrm{Yes}^{\mathrm{b}}$ & Yes & Yes & VOC speciation from May et al. (2014) \\
\hline 9 & Aromatic $^{\mathrm{a}}$ & Yes $^{b}$ & Yes & Yes & S/IVOCs modeled using the toluene parameterization \\
\hline 10 & SVOC $_{\text {cooking }}{ }^{\mathrm{a}}$ & $\mathrm{Yes}^{\mathrm{c}}$ & Yes & Yes & $\begin{array}{l}\text { SVOCs from food cooking modeled using the volatility } \\
\text { distribution of Louvaris et al. (2017) }\end{array}$ \\
\hline
\end{tabular}

a Same as the Base simulation but with differences noted in the "Additional details" column. ${ }^{\mathrm{b}}$ Assumes volatility of food cooking POA to be similar to volatility of biomass burning. ${ }^{\mathrm{c}}$ Uses measured volatility of food cooking POA.

tionalized products with no further oxidation. This simulation investigated the influence of multigenerational aging on ambient SOA. The $\mathrm{VOC}_{\text {spec }}(8)$ simulation updated the VOC speciation for on- and off-road gasoline and diesel vehicles based on a comprehensive set of measurements performed on an in-use fleet (May et al., 2013a, b). This simulation examined the influence of updated emissions profiles on the non-IVOC contribution to SOA. The Aromatic (9) simulation assumed that the oxidation of SVOCs and IVOCs to form SOA was modeled using toluene. There were two reasons for choosing toluene. First, both mono- and polycyclic aromatic compounds are found in gasoline and diesel fuel (Gentner et al., 2012) and in tailpipe emissions from mobile sources (Zhao et al., 2015, 2016), and oxygenated aromatic compounds such as phenols, guaiacols, and syringols are found in biomass burning emissions (Schauer et al., 2001; Stockwell et al., 2015). Second, aromatic compounds, similar to alkanes, have been studied in detail for their potential to form SOA and are recognized to form more SOA than linear alkanes for the same carbon number. This simulation provided an upper-bound estimate for SOA formation from the oxidation of SVOCs and IVOCs. Finally, the SVOC cooking $_{\text {(10) simula- }}$ tion used a hydrocarbon/linear alkane distribution based on the measured volatility distribution of Louvaris et al. (2017) to represent POA from food cooking sources. This simulation examined the effect of a more realistic volatility distribution for food cooking POA on mass concentrations of POA and SOA from SVOCs.

The UCD/CIT model was run on the High Performance Computing Cluster run by Engineering Network Services at Colorado State University. Although the number of cores varied based on availability, on average each simulation used 96 cores and required 5 days to execute 19 simulated days. Since each set included four sub-simulations, each simulation required $\sim 5$ days and all simulations in this work required $\sim 180$ days of computational time.

\subsection{Measurements for model evaluation}

Model predictions were evaluated against gas-phase measurements of SOA precursors and particle-phase measurements of OA mass concentrations and composition. Here, we briefly describe the primary measurement data and any post- 
processing of the data we performed prior to undertaking the model evaluation.

Gas-phase measurements of SOA precursors were from two different sources. The first source was routine dailyaveraged measurements of single-ring aromatics made by the South Coast Air Quality Management District (SCAQMD, 2017) in southern California at three different sites: north Los Angeles, Riverside, and Long Beach. While measurement data were available at three other sites, data were not available for 2005, our modeled year, and hence not included. These gas-chromatography-based measurements were available every 12th day and included the following aromatic species: benzene, toluene, $o / m / p$-xylene, ethyl-benzene, and styrene. Since there was little overlap between the modeled episode (14-day period over July-August) and available aromatic data, the measurement data were averaged over a 3-month period in the summer (15 May to 15 September) and then compared to the episode-averaged model predictions. The second source was gas-chromatography massspectrometry measurements of single-ring aromatics (Borbon et al., 2013) and IVOCs (Zhao et al., 2014) made at the Pasadena ground site in the months of May and June of 2010 as part of the CalNex campaign. The single-ring aromatics were measured every hour and included the following species: benzene, toluene, $o / m / p$-xylene, ethyl-benzene, and styrene. The IVOCs were measured every $3 \mathrm{~h}$ and included most of the reduced and oxidized organic species with a carbon number larger than 12 . Since these measurements were from a different time period, we compared campaignaveraged measurements against episode-averaged model predictions.

Particle-phase measurements were from two different sources as well. The first source was routine daily-integrated measurements of organic carbon (OC) in southern California from four sites in the Chemical Speciation Network (CSN; central Los Angeles, Riverside, Simi Valley, and Escondido) and six sites in the Interagency Monitoring of Protected Visual Environments (IMPROVE) network (San Rafael, Riverside-Rubidoux, San Gorgonio Wilderness, Joshua Tree NP, Agua Tibia, and San Gabriel). The CSN is a network of $\sim 50$ urban measurement sites across the United States where pollutant concentrations are typically higher, more variable, and representative of local sources, and measurements are made once every 3 days. IMPROVE is a network of $\sim 200 \mathrm{rural} / \mathrm{remote}$ continental sites typically located in national parks across the United States where pollutant concentrations are lower, less variable, and representative of regional influences, and measurements are made once every 3 days. Over the 14-day episode modeled in this work, three measurements from the CSN and five measurements from the IMPROVE network were available for comparison. We used an organic-aerosol-to-organic-carbon ratio (OA : OC) of 1.6 to calculate OA at the CSN sites (Docherty et al., 2011, measured an OA : OC ratio of 1.77 during the SOAR-1 campaign, after correction with the updated calibra- tion of Canagaratna et al., 2015) and a ratio of 2.1 to calculate OA at the IMPROVE sites (Turpin and Lim, 2001). The CSN data are artifact corrected but we subtracted $0.5 \mu \mathrm{g} \mathrm{m}^{-3}$ from the calculated OA mass concentrations to blank correct the data (Subramanian et al., 2004). The IMPROVE data are both blank and artifact corrected. We note that a negative evaporation artifact has been reported at IMPROVE sites in the southeast US (Kim et al., 2015), but it is not known whether such an artifact may be present in this region and no correction has been made. The second source was particle measurements made at the ground site in Riverside as part of the SOAR-1 campaign during the summer of 2005 (Docherty et al., 2008, 2011). These measurements included hourly-averaged mass concentrations and elemental ratios of $\mathrm{H}: \mathrm{C}$ and $\mathrm{O}: \mathrm{C}$ for OA, as well as estimates of the POASOA split based on results from a positive matrix factorization analysis.

\section{Results}

\subsection{POA and SOA precursor emissions}

Gas- and particle-phase emissions of organic compounds in the $8 \mathrm{~km}$ southern California domain, averaged over the 14day episode, are shown in Fig. 1 . The $8 \mathrm{~km}$ domain, shown in Fig. S1 in the Supplement, includes the entire Los Angeles metropolitan statistical area, parts of the Pacific Ocean, and forested areas surrounding the urban area. The emissions are color-coded by source type and include all species that contribute to direct emissions and atmospheric formation of OA. These do not include emissions of marine POA since those were calculated in line in the UCD/CIT model. Since the POA repartitioned between the gas and particle phases after emission, POA was split into POA and SVOC that represented the particle and gas portions of POA partitioned at an urban OA mass concentration of $9 \mu \mathrm{g} \mathrm{m}^{-3}$. We chose $9 \mu \mathrm{m} \mathrm{m}^{-3}$ to partition POA because the campaign-averaged OA mass concentration at Riverside during SOAR-1 was $9 \mu \mathrm{g} \mathrm{m}^{-3}$. If one discounts the POA emissions in the "other" category (which is mostly made of road, agricultural, and construction dust), the repartitioning results in about $60 \%$ of the POA emitted evaporating as SVOC vapors; these vapors oxidize in the atmosphere to form SOA. As noted earlier, a relatively more volatile treatment compared to that described in the recent literature suggests that we may have overestimated the POA evaporation from food cooking sources. Mobile sources accounted for $20 \%$ of the POA and $35 \%$ of the SVOC vapors and competed with food cooking as an important source of primary emissions and one which accounted for $15 \%$ of the POA and $44 \%$ of the SVOC vapors. IVOC, long-alkane, and aromatic emissions were roughly on the same order of magnitude but taken together were approximately an order of magnitude larger than the POA emissions. This suggests that even at low SOA mass yields (say $<10 \%$ ), 


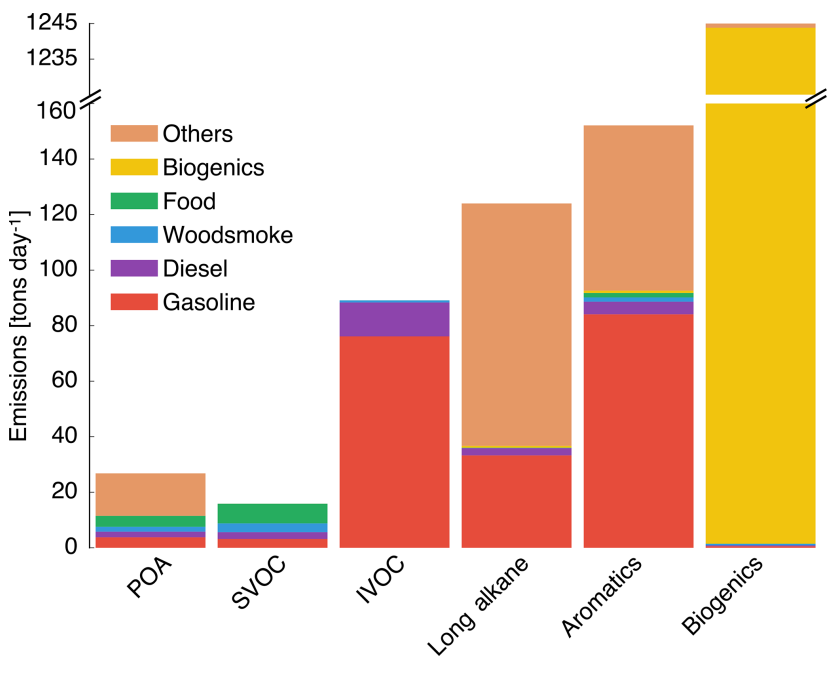

Figure 1. Episode-averaged gas- and particle-phase organic emissions in metric tons per day over the $8 \mathrm{~km}$ southern California domain resolved by source. POA and SVOC represent the particleand gas-phase emissions partitioned to an OA mass concentration of $9 \mu \mathrm{g} \mathrm{m}^{-3}$. SVOC, IVOC, long alkanes, aromatics, and biogenics represent gas-phase emissions of precursor species that are modeled to form SOA. We note that recent measurements suggest that POA from food cooking sources is less volatile than assumed in these results.

the OA formed from the oxidation of these precursors could quickly exceed direct emissions of POA.

Emissions of total IVOCs were slightly lower than those for long alkanes (by $\sim 30 \%$ ) and aromatics (by $\sim 40 \%$ ) but a factor of 2 higher than the sum of POA and SVOCs. Previously, IVOC emissions have been estimated by scaling POA emissions by a factor of 1.5 to 3 derived from gas-particle partitioning calculations (Dzepina et al., 2009; Shrivastava et al., 2008) and from atmospheric measurements (Ma et al., 2017). While our estimates for IVOC emissions are within the previously used range, our estimates were informed by a broader suite of source measurements, which will help reduce the uncertainty in IVOC emissions and related SOA formation in atmospheric models. IVOC emissions from mobile sources were similar to aromatic emissions but twice the long-alkane emissions from the same source. We note that in this work we only considered IVOC emissions from combustion sources, but recent work suggests that volatile chemical products present in sources such as pesticides, coatings, cleaning agents, and personal care products may be a large source of IVOCs in urban environments (McDonald et al., 2018).

Mobile sources - dominated by gasoline use - accounted for a much larger fraction of the anthropogenic SOA precursors (85\% of IVOCs, $27 \%$ of long alkanes, and $55 \%$ of aromatics) in this study. Hence, mobile source regulation on precursor emissions from gasoline vehicles (e.g., limits on emissions of unburned hydrocarbons) has and could have a much larger influence on controlling ambient OA than regulating direct emissions of POA, although this ultimately depends on the extent of conversion of these species to SOA. Finally, biogenic precursor emissions of isoprene, monoterpenes, and sesquiterpenes were about a factor of 3 higher than the combined emissions of SVOCs, IVOCs, long alkanes, and aromatics and will continue to be an important source of SOA in southern California. However, their impact on urban OA/SOA will be smaller since these emissions are primarily limited to regions outside the urban areas.

\subsection{Spatial distribution of OA concentrations and bulk composition}

In Fig. 2 we plot predictions of the 14-day-averaged mass concentrations for OA, POA, SOA, and contributions from three lumped SOA precursors (long alkanes and aromatics, SVOC and IVOCs, and biogenic VOCs) from the Base case simulation. We used the terminology developed by Murphy et al. (2014) to describe the SOA from the different sources. To reiterate, the Base case simulation included a semi-volatile treatment of POA; SOA formation from oxidation of SVOCs, IVOCs, and VOCs; multigenerational aging; and SOA parameterizations that accounted for the influence of chamber vapor wall losses. The mass concentrations in Fig. 2 account for $\mathrm{SOA}$ formation under varying $\mathrm{NO}_{x}$ levels as per Eq. (2) (logarithmic dependence on the VOC : $\mathrm{NO}_{x}$ ratio). We chose Eq. (2) because it produced the highest SOA mass concentrations and presented an upper bound on SOA formation.

The highest OA mass concentrations were found in three general regions: the densely populated Los AngelesOrange-Riverside County region, likely attributed to heavy transportation emissions; along the coast as a result of sea spray emissions; and in biogenic-VOC-dominated areas. In central Los Angeles (grid cell containing the CSN site), OA accounted for $38 \%$ of the modeled non-refractory $\mathrm{PM}_{2.5}$ mass concentration with 20,25 , and $18 \%$ contributions from sulfate, nitrate, and ammonium aerosol. A sensitivity simulation that turned emissions of marine POA off suggested that the marine POA mass concentrations in central Los Angeles were $\sim 0.9 \mu \mathrm{g} \mathrm{m}^{-3}$, which were considerably higher than the coastal measurements made during CalNex in 2010 (Hayes et al., 2013). Measured mass concentrations of POA over the open ocean west of California were $\sim 0.2 \mu \mathrm{g} \mathrm{m}^{-3}$ during CalNex in 2010, and it was expected that these mass concentrations would be substantially lower by the time they were transported to central Los Angeles (Hayes et al., 2013). Sea spray emissions in the UCD/CIT model are based on the parameterization of Gong et al. (2003) and may need to be revisited in the future.

The broader spatial trends of OA, POA, and SOA were in line with results from earlier chemical transport model studies that have treated POA as semi-volatile and modeled SOA formation from SVOCs and IVOCs (Ahmadov et al., 2012; 


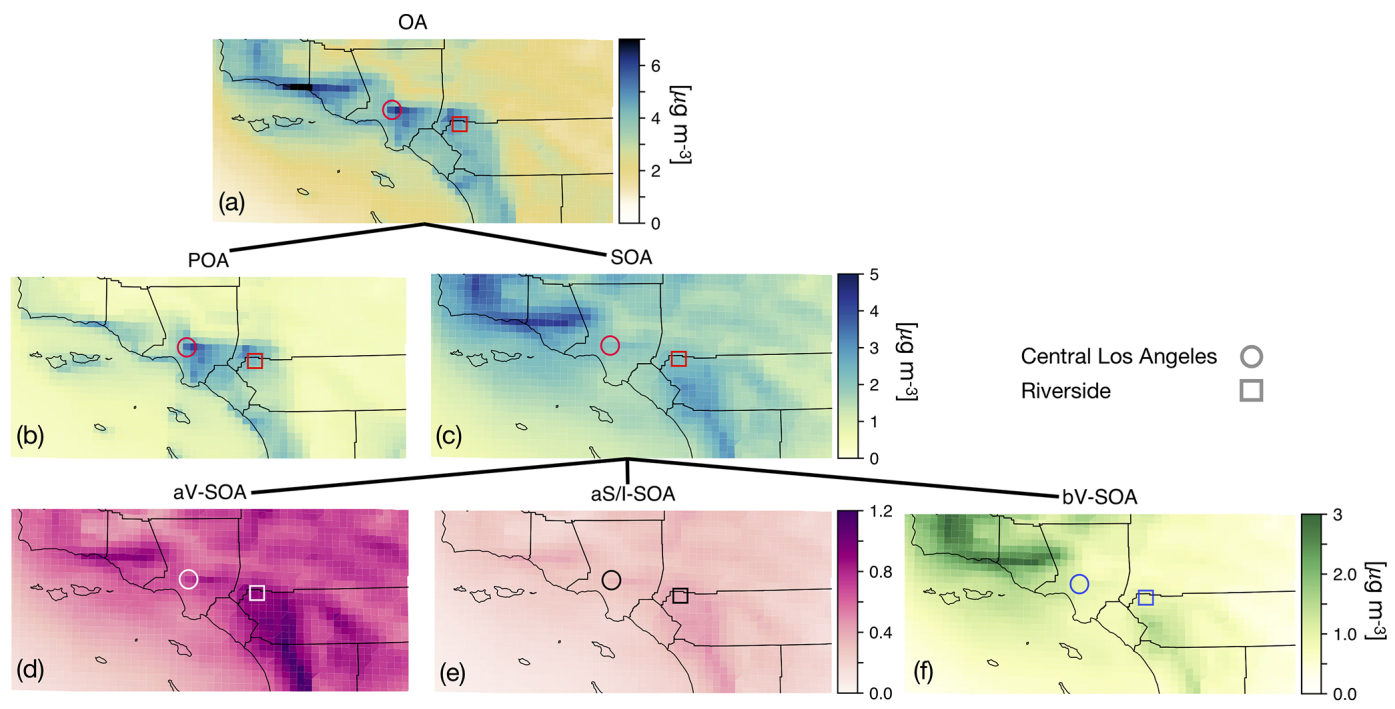

Figure 2. The 14-day-averaged model predictions of mass concentrations for OA, POA, SOA, aV-SOA, aS/I-SOA, and bV-SOA in $\mu$ g $\mathrm{m}^{-3}$ over the southern California domain from the Base simulation. We note that recent measurements suggest that POA from food cooking sources is less volatile than assumed in these results.

Jathar et al., 2017a; Koo et al., 2014; Robinson et al., 2007; Tsimpidi et al., 2010). POA mass concentrations were highest in upwind (e.g., $3.4 \mu \mathrm{g} \mathrm{m}^{-3}$ in central Los Angeles) and lower in downwind (e.g., $2.7 \mu \mathrm{g} \mathrm{m}^{-3}$ in Riverside) locations as the POA emissions that were transported away from the source region evaporated with dilution. SOA mass concentrations, in contrast to POA, had a more regional presence with lesser differences between the upwind and downwind regions (e.g., $2.4 \mu \mathrm{g} \mathrm{m}^{-3}$ in Riverside vs. $2.2 \mu \mathrm{g} \mathrm{m}^{-3}$ in central Los Angeles) or in regions with high emissions of biogenic VOCs (e.g., $2.5 \mu \mathrm{g} \mathrm{m}^{-3}$ inside the Los Padres National Forest). To assess the relative contribution of POA and SOA to total OA, we plot the POA : SOA ratio in Fig. S2, which suggests a POA : SOA ratio of $\sim 1.6$ in near-source regions and lower elsewhere, e.g., $\sim 0.4,0.8$, and 1.2 in representative marine, biogenic-VOC-dominated, and urban downwind regions. These POA : SOA splits qualitatively aligned with the hydrocarbon-like and oxygenated organic aerosol (HOA and OOA) splits estimated in aerosol mass spectrometer datasets in urban locations worldwide (Jimenez et al., 2009; Zhang et al., 2007). However, we predict POA : SOA $\sim 1$ for Riverside during SOAR-1, compared to a measured ratio of $\sim 0.25$ (Docherty et al., 2008), which indicates that SOA may still be underestimated in the model. A comparison of the OA composition predictions with the aerosol mass spectrometer measurements is described in Sect. 4.

Panels (d) through (f) show contributions of three distinct SOA precursor classes to total SOA. Alkane and aromatic VOCs - included as SOA precursors in most atmospheric models - appeared to contribute a maximum of $1.2 \mu \mathrm{g} \mathrm{m}^{-3}$ of what we refer to as aV-SOA downwind of the source region. The majority of this aV-SOA (75\%) originated from aro- matic precursors, implying that alkane VOCs are unlikely to contribute much to the anthropogenic SOA or total OA burden in urban areas, consistent with our earlier work (Cappa et al., 2016; Jathar et al., 2016). We note that emissions inventories typically only include alkane species with carbon numbers less than 12 (Pye and Pouliot, 2012), and longer alkanes with carbon numbers larger than 12 are included as part of the POA, SVOC, and IVOC emissions. Together aSSOA and aI-SOA mass concentrations exhibited a similar spatial pattern over the domain but were substantially lower than the aV-SOA mass concentrations - reaching a maximum of only $0.5 \mathrm{\mu g} \mathrm{m}^{-3}$. The lower aS-SOA and aI-SOA mass concentrations were somewhat contrary to earlier work that has argued that SVOCs and IVOCs are an equal or dominant precursor of anthropogenic SOA when compared to aVSOA, especially in urban areas (Jathar et al., 2014, 2017a; Woody et al., 2016). The reason for these lower concentrations can be partially attributed to the precursor-dependent influence of accounting for vapor wall losses in chamber experiments (probed in greater detail in Sect. 3.4). Biogenic SOA or bV-SOA mass concentrations exceeded $3.2 \mu \mathrm{g} \mathrm{m}^{-3}$ in regions with high biogenic emissions but were slightly less than $1 \mu \mathrm{g} \mathrm{m}^{-3}$ in urban regions where the POA mass concentrations were the highest. Previous work has suggested that the bV-SOA in urban regions is formed outside but later transported to the urban region (Hayes et al., 2015; Heo et al., 2015). Overall, the averaged results over the urban areas appeared to be split evenly between POA, anthropogenic SOA (aV-SOA + aS-POA + aI-SOA), and biogenic SOA (bV-SOA). 


\subsection{Precursor contributions to $\mathrm{OA}$ and SOA}

We examined the absolute OA mass concentrations and precursor contributions to SOA in central Los Angeles across four different simulations to better understand the effect of successive updates: semi-volatile and reactive POA, IVOCs, and accounting for vapor wall losses. We chose central Los Angeles (grid cell containing the CSN site) as our study area as it is representative of an urban location with a large population density and suffers from some of the poorest air quality in the United States (ALA, 2017); results from the sensitivity simulations in Sect. 3.5 are also discussed at this specific site. Results at other urban locations (e.g., Riverside, Simi Valley) had similar SOA precursor fractional contributions although the absolute concentrations did vary a little (see Fig. S3). In Fig. 3, we plot the 14-day-averaged, precursor-resolved OA mass concentrations and precursor contributions to SOA in Los Angeles from two pairs of four different simulations. The two pairs represent model predictions based on the lowand high- $\mathrm{NO}_{x}$ parameterizations.

Semi-volatile and reactive POA. Differences in the Traditional and SVOC simulations were used to highlight the influence of including a semi-volatile and reactive treatment of POA. The semi-volatile POA treatment resulted in evaporation of the primary POA emissions from combustion sources (on- and off-road gasoline and diesel, woodsmoke, biomass burning, and food cooking) and reduced POA mass concentrations by $35 \%$ in central Los Angeles. A ratio of the POA mass concentrations from the SVOC simulation to those from the Traditional simulation suggested that the POA mass was reduced by approximately $30 \%$ to $50 \%$ in the urban environment around the central Los Angeles site (Fig. S4). Overall, the POA reductions appeared to be smaller than those implied by the volatility distributions of May and coworkers (May et al., 2013a, b, c) and those simulated in other atmospheric models (Robinson et al., 2007). For gasoline, diesel, and biomass burning, May and coworkers (May et al., 2013a, b, c) proposed a $45 \%$ to $80 \%$ reduction in POA mass concentrations at ambient OA mass concentrations between 1 and $10 \mu \mathrm{g} \mathrm{m}^{-3}$. This difference was mainly because we only modeled certain combustion-related POA to be semi-volatile (i.e., gasoline, diesel, biomass burning, and food cooking sources) while earlier modeling work has considered POA from all sources to be semi-volatile (e.g., marine, dust). The use of a less volatile and more realistic food cooking POA than that used in this work (informed by the works of Woody et al., 2016, and Louvaris et al., 2017) would tend to further increase the discrepancy between our work and the findings of May and coworkers. Hu et al. (2014) found that the combustion sources considered to be semivolatile in this work accounted for about half of $\mathrm{PM}_{2.5}$ mass concentrations in Los Angeles. The POA mass reductions shown here are conservative and might have been larger if there was evidence that sources other than those consid-

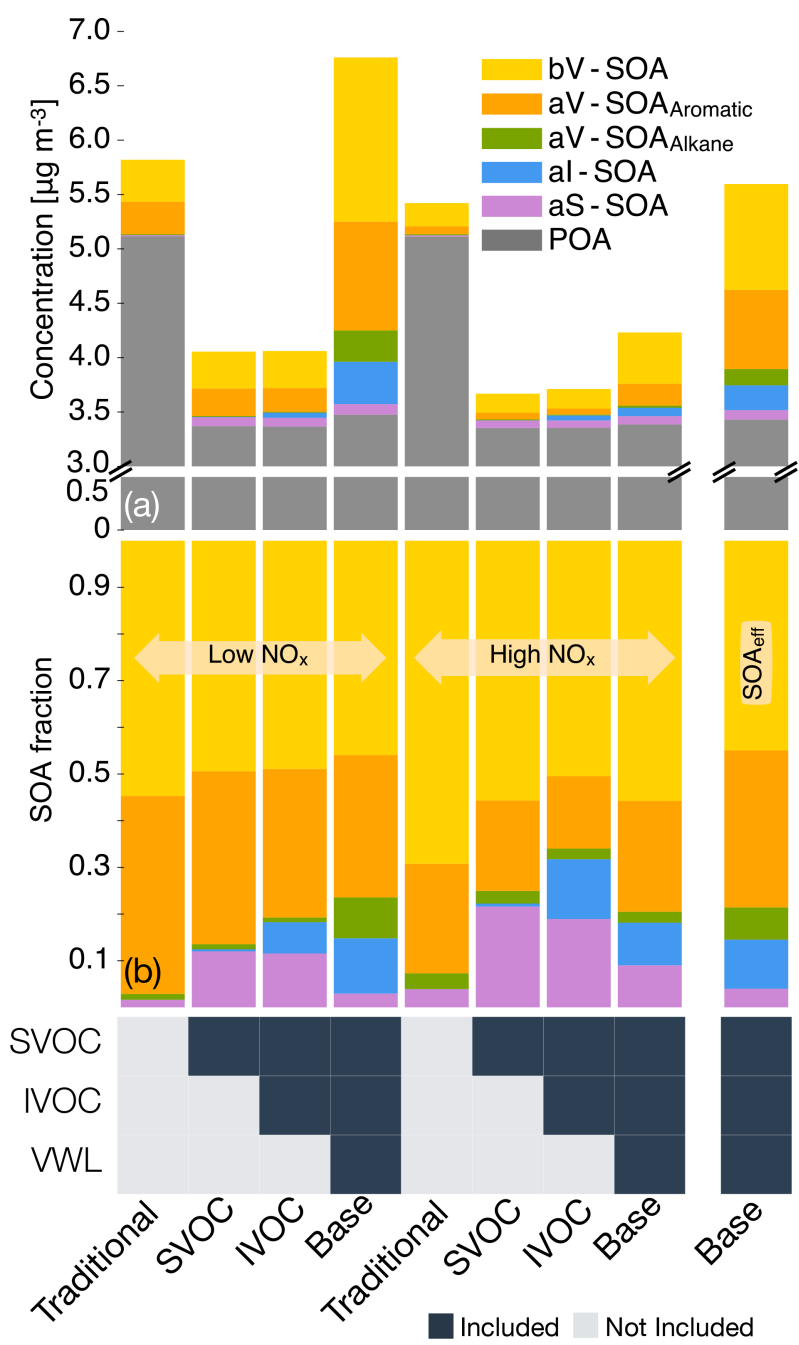

Figure 3. The 14-day-averaged model predictions of POA and SOA mass concentrations and precursor contributions at the central Los Angeles site from the sensitivity simulations that examined the influence of updates made in this work. Panel (a) shows absolute concentrations and panel (b) shows precursor contributions. The legend at the bottom tracks how the different pathways (i.e., SOA formation from SVOCs; SOA formation from IVOCs; and correction for chamber vapor wall losses, VWL) were turned on for the different simulations. Model predictions from the low- and high- $\mathrm{NO}_{x}$ simulations are shown separately. Model predictions to the extreme right are from accounting for the influence of $\mathrm{NO}_{x}$ on SOA formation using Eq. (2). We note that recent measurements suggest that POA from food cooking sources is less volatile than assumed in these results.

ered here (e.g., marine, dust) produced POA that was semivolatile too, although this scenario seems unlikely.

Allowing the POA vapors or SVOCs to react resulted in only a small fraction of their oxidation products condensing back as aS-SOA. For example, of the $1.75 \mu \mathrm{g} \mathrm{m}^{-3}$ of POA lost at the central Los Angeles site, only $0.082 \mu \mathrm{g} \mathrm{m}^{-3}$ for the low- $\mathrm{NO}_{x}$ simulations and $0.068 \mu \mathrm{g} \mathrm{m}^{-3}$ for the high- $\mathrm{NO}_{x}$ 
simulations was regained as aS-SOA from oxidation reactions. This implied a very low chemical conversion efficiency ( $\sim 4 \%$ ) for the POA-to-SVOC-to-aS-SOA pump within the urban area (Miracolo et al., 2010). The SVOCs, at an ambient concentration of $9 \mathrm{\mu g} \mathrm{m}^{-3}$, from gasoline exhaust, diesel exhaust, and biomass burning emissions had an average carbon number between 18 and 20. Calculations with a box model version of the SOM suggested that the SOA mass yields for $\mathrm{C}_{18}$ and $\mathrm{C}_{20}$ alkanes were between $33 \%$ and $86 \%$ where the range includes yields for low- $\mathrm{NO}_{x}$ and high- $\mathrm{NO}_{x}$ parameterizations. One possible explanation for the difference between the chemical conversion efficiency in the 3D model and box model yields was that only a small fraction of the SVOCs had the opportunity to react with $\mathrm{OH}$ and form SOA before they were transported out of the urban area. If we assume that most of the sS-SOA in the grid cell that contains the Los Angeles site was from the oxidation of SVOCs released in that grid cell and from grid cells that are up to two grid cells away, our results do not appear unrealistic. For example, for an SOA precursor with an $\mathrm{OH}$ reaction rate constant of $2.4 \times 10^{-11} \mathrm{~cm}^{-3}$ molecules ${ }^{-1} \mathrm{~s}^{-1}$ (average value from a $\mathrm{C}_{18}$ and $\mathrm{C}_{20}$ linear alkane) and an SOA mass yield of $60 \%$ (average from the SOA mass yield range described earlier for a $\mathrm{C}_{18}$ and $\mathrm{C}_{20}$ linear alkane), the chemical conversion efficiency would be $3.5 \%-15 \%$ with a daily-averaged $\mathrm{OH}$ concentration of $1.5 \times 10^{6}$ molecules $\mathrm{cm}^{-3}$ and a reaction time of $0.5-2.3 \mathrm{~h}$. A reaction time of 0.5 to $2.3 \mathrm{~h}$ corresponds to a transport of $4 \mathrm{~km}$ (half a grid cell) and $20 \mathrm{~km}$ ( 2.5 grid cells) at an average wind speed of $2.4 \mathrm{~m} \mathrm{~s}^{-1}$ (Weather Spark).

The low- and high- $\mathrm{NO}_{x}$ parameterizations had little effect on the aS-SOA mass concentrations presumably because the $n$-dodecane-based parameterization used for semi-volatile POA exhibited marginal differences in SOA production under low- and high-NO $\mathrm{NO}_{x}$ environments (Loza et al., 2014). Finally, SOA parameterizations based on including the vapor wall loss effect only marginally increased the aS-SOA mass concentrations, especially when viewed in light of the SOA increases from other precursors. We examine the precursorresolved vapor wall loss effect in more detail in Sect. 3.4. For the Base simulations, the aS-SOA mass concentrations were a factor of 10 and 2 lower than the aV-SOA mass concentrations for the low- and high- $\mathrm{NO}_{x}$ parameterizations respectively.

IVOC. Differences in the SVOC and IVOC simulations were used to determine the influence of including SOA formation from IVOCs. For both the low- and high-NO $\mathrm{NO}_{x}$ simulations, IVOCs contributed marginally to the aI-SOA mass concentrations in Los Angeles $\left(\sim 0.045 \mu \mathrm{g} \mathrm{m}^{-3}\right)$ and elsewhere too (see Figs. S3 and S4). The aI-SOA mass concentrations were about half of the aS-SOA mass concentrations for both the low- and high- $\mathrm{NO}_{x}$ simulations. When compared to the aV-SOA mass concentrations, the aI-SOA mass concentrations were slightly lower for the high- $\mathrm{NO}_{x}$ simulations $(\sim 35 \%)$ but about a factor of 3.3 lower for the low- $\mathrm{NO}_{x}$ simulations. The inclusion of vapor wall losses seemed to make aI-SOA as or more important than aS-SOA but still less important than aV-SOA; the aI-SOA mass concentrations were a factor of 3.2 and 2.9 lower than the aV-SOA mass concentrations for the Base simulations for the lowand high- $\mathrm{NO}_{x}$ simulations respectively. Our simulations imply that IVOCs might be as influential as SVOCs as a bulk class of SOA precursors, but they were still less important than the traditional SOA precursors (that included long alkanes and aromatics) in contributing to ambient SOA levels. In this work, the IVOC contribution to SOA was smaller compared to that from traditional SOA precursors mostly because IVOC emissions were only about a third of the traditional SOA precursors (see Sect. 3.1 for details on emissions). So although IVOCs have higher SOA yields than most of the traditional SOA precursors, the significantly lower IVOC emissions more than offset the increased SOA formation from higher yields. While there are exceptions (e.g., Tsimpidi et al., 2010; Jathar et al., 2017a), our results did not align with previous box (e.g., Dzepina et al., 2009; Hayes et al., 2015; Ma et al., 2017) and 3-D (e.g., Bergström et al., 2012; Zhang et al., 2013) modeling literature that has found IVOCs to be similar to or more important than traditional SOA precursors in contributing to ambient SOA levels. Below we discuss three main reasons for this inconsistency.

First, some previous estimates of IVOC emissions are likely to be less representative of the in-use gasoline- and diesel-powered sources and unconstrained for biomass burning sources. IVOC emissions in most atmospheric models have previously been determined by scaling emissions of POA or by calculating partitioning with the measured POA, with scaling factors typically on the order of 1.5 (e.g., Shrivastava et al., 2008) but as large as 3 (e.g., Dzepina et al., 2009). These factors have been calculated from emissions data from two medium-duty gasoline vehicles built more than two decades ago and a POA volatility distribution from a small off-road diesel engine (Robinson et al., 2007). Additionally, since POA is semi-volatile the POA mass in the particle phase will change with OA loading, which can complicate the use of a scaling based on POA (but this is addressed by the partitioning method used in some studies). Zhao et al. (2015) provided some evidence for this where they found that the POA-based scaling did not work that well for modern diesel vehicles and instead recommended the use of an NMOG-based scaling. We note that Ma et al. (2017) used the IVOC estimates of Zhao et al. (2015) and still found IVOCs to be comparable to VOCs in terms of SOA production in the Los Angeles area. Second, the SOA formation from IVOCs in most models to date has not been experimentally constrained. Most schemes to model SOA formation from IVOCs have relied on an ad hoc aging scheme where IVOCs and their oxidation products react with the $\mathrm{OH}$ radical to form lower-volatility products with ultimate SOA yields of $100 \%$ (Robinson et al., 2007). These schemes do not account for fragmentation reactions and have not been comprehensively validated against experimental data. Jathar et 
al. (2016) showed that such schemes may significantly overestimate the net aerosol production from SOA precursors. Finally, most models use SOA parameters that do not account for the effect of vapor wall losses in chamber experiments. This effect and its particular influence on the IVOC contribution to SOA is discussed in Sect. 3.4. In this work, we (i) rely on a comprehensive set of IVOC emissions estimates made from measurements performed on more representative sources, (ii) model fragmentation reactions during IVOC oxidation, (iii) to some degree constrain SOA formation from IVOCs with chamber experiments, (iv) to some degree account for the influence of vapor wall losses in chamber experiments, and (v) include all of the previously mentioned updates in a chemical transport model. Hence, we argue that our findings on the IVOC contribution to SOA might be more robust than those modeled in earlier studies.

Traditional VOCs. For the Base simulations in Los Angeles, aromatics accounted for $33 \%$ of the total SOA in Los Angeles and were the most important anthropogenic precursor of SOA. Alkane contributions to SOA were less than $10 \%$ for both the low- and high- $\mathrm{NO}_{x}$ simulations. Biogenic VOCs accounted for $46 \%$ and $55 \%$ of the total SOA for the low- and high- $\mathrm{NO}_{x}$ simulations respectively and were clearly the most important precursor of SOA at the central Los Angeles site. After accounting for the influence of $\mathrm{NO}_{x}$ based on Eq. (2), the isoprene, monoterpene, and sesquiterpene contributions to bV-SOA were $23 \%, 68 \%$, and $9 \%$ respectively, suggesting a strong monoterpene contribution to SOA in southern California. As biogenic VOCs react very quickly with $\mathrm{OH}$ and $\mathrm{O}_{3}$ (chemical lifetimes of a few hours), most of the biogenic SOA at this site was likely formed outside the urban airshed and transported to this location, as suggested by Kleeman et al. (2007), Hayes et al. (2015), and Heo et al. (2015).

\subsection{Influence of vapor wall losses}

SOA parameterizations that accounted for the influence of vapor wall losses in chambers seemed to have had a large effect on the absolute mass concentrations of SOA. This can be seen by comparing model results between the IVOC and Base simulations in Fig. 3. The SOA mass concentrations were enhanced by a factor of 10.1 and 2.6 for the low- and high- $\mathrm{NO}_{x}$ simulations respectively and consistent with previous 3D simulations (Cappa et al., 2016). However, they were slightly higher than the range of enhancements reported by Zhang et al. (2014) and estimated by Krechmer et al. (2016) based on analyses of chamber data. The SOA enhancements resulted in an OA enhancement of 1.66 and 1.14 in the lowand high- $\mathrm{NO}_{x}$ simulations, which were lower than the SOA enhancements since SOA only accounted for a fraction of the OA mass. Differences in enhancements in the low- and high$\mathrm{NO}_{x}$ simulations suggest that the vapor wall loss effect was modified by the $\mathrm{NO}_{x}$ level where the enhancement may be lower in urban source regions with higher $\mathrm{NO}_{x}$ but higher in

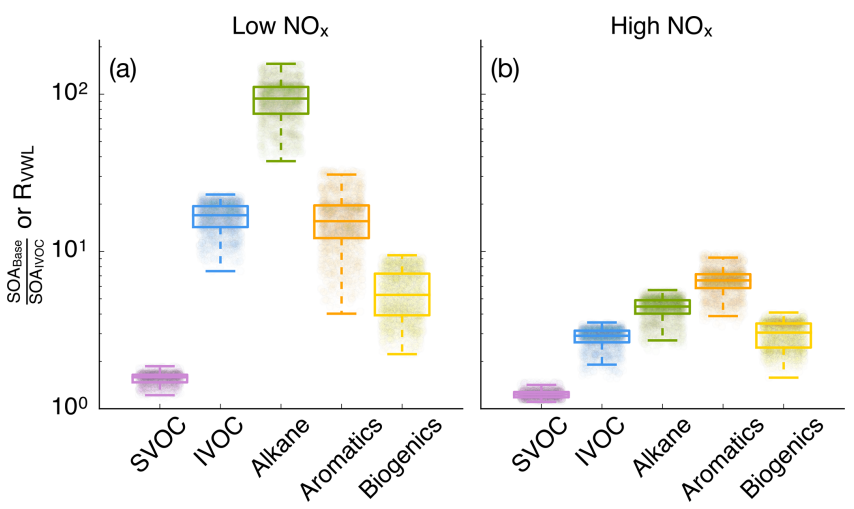

Figure 4. Ratio of model predictions from the Base simulation that accounts for the influence of vapor wall losses to model predictions from the IVOC simulation that does not account for the influence of vapor wall losses. Ratios are calculated from the 14-day-averaged results for the whole domain and are resolved by precursor. Panels (a) and (b) show results from the low- and high- $\mathrm{NO}_{x}$ simulations respectively.

rural/remote continental regions with lower $\mathrm{NO}_{x}$. Since urban SOA mass concentrations are usually higher than those in rural/remote continental regions, an implication of this $\mathrm{NO}_{x}$-modified enhancement is that accounting for vapor wall loss artifacts will tend to reduce gradients in SOA mass concentrations between urban and rural/remote continental regions and make SOA more of a regional pollutant similar to ozone $\left(\mathrm{O}_{3}\right)$.

Different precursors contributed in varying degrees to the SOA enhancement. The precursor-resolved enhancements are visualized in Fig. 4 where we plot the ratio of the 14-dayaveraged model predictions of the SOA mass concentrations from the Base simulation to those from the IVOC simulation for each grid cell in the southern California domain (dots) and overlay box-whisker plots based on those data. For all precursors the enhancements were higher for the low- $\mathrm{NO}_{x}$ simulations compared to the high- $\mathrm{NO}_{x}$ simulations. SVOCs showed the smallest enhancement at both the low and high $\mathrm{NO}_{x}$ levels (median of 1.6 and 1.2) and hence their fractional contribution to total SOA was reduced in the Base simulation when compared to the IVOC simulation. Alkanes showed the largest enhancement in the low- $\mathrm{NO}_{x}$ simulations (median of 94) and the second largest enhancement in the high- $\mathrm{NO}_{x}$ simulations (median of 4.5). Despite the large enhancements, alkanes still contributed marginally to total SOA in the Base simulations because the baseline contribution of alkanes to SOA was small in the IVOC simulations $(<3 \%)$. IVOCs exhibited a larger enhancement (median of 17 and 2.9) compared to SVOCs and a smaller enhancement compared to alkanes in both simulations, despite using the same surrogate (i.e., $n$-dodecane) to model SOA formation. The reason for varying enhancements in SVOC, IVOCs, and alkanes, despite using the same surrogate (i.e., $n$-dodecane), was that the vapor-wall-loss-related enhancement was inversely related to 
the carbon number where larger carbon number precursors (e.g., SVOC that had an average carbon number of 18 to 20) showed smaller enhancements and smaller carbon number precursors (e.g., alkanes that included species between carbon numbers of 6 to 12) showed larger enhancements. The simplest explanation for this inverse relationship is that larger precursors and their oxidation products, relatively speaking, have shorter chemical lifetimes and undergo fewer chemical reactions before condensing, which make them less susceptible to being lost to the walls (see Fig. S5 where we plot the vapor-wall-loss-related enhancement in SOA yields as a function of the carbon number at an OA mass concentration of $9 \mu \mathrm{g} \mathrm{m}^{-3}$ ). Of the two other important precursors, aromatics displayed the largest enhancement in the high- $\mathrm{NO}_{x}$ simulations (median of 6.6) and were tied with IVOCs for the second largest enhancement in the low- $\mathrm{NO}_{x}$ simulations (median of 16) while biogenic VOCs showed the lowest enhancement after SVOC in both the low- $\mathrm{NO}_{x}$ and high- $\mathrm{NO}_{x}$ simulations. Accounting for vapor wall loss artifacts is expected to result in an increase in the aromatic contribution to SOA when compared against biogenic VOCs. Vapor wall loss rates in Teflon chambers might be much higher $(\sim$ factor of 5) than those used in this work to develop the SOM parameterizations (Huang et al., 2018; Krechmer et al., 2016; Sunol et al., 2018), the use of which will tend to increase SOA mass concentrations even further. This new understanding will need to be considered in the future.

\subsection{Sensitivity analysis}

Results from the sensitivity simulations that examined uncertainties in select model inputs are shown in Fig. 5 where we plot the 14-day-averaged model predictions from these simulations at the central Los Angeles site. We also plot model predictions from the Base simulations as all the sensitivity simulations have been performed using the Base simulation as the reference (see Table 3 for details about the simulations). Model predictions from the low- and high- $\mathrm{NO}_{x}$ simulations are shown separately. The No Aging simulations decreased the SOA mass concentrations by almost an order of magnitude, demonstrating the importance of modeling multigenerational aging in the SOM. The inclusion of oligomerization reactions that may enhance the partitioning of semivolatile species may alter this finding. The No Aging simulations produced a very different precursor contribution to total SOA compared to the Base simulations and the changes in the precursor contribution were also different between the low- and high- $\mathrm{NO}_{x}$ simulations. For instance, the aV-SOA contributions to total SOA increased from $39 \%$ to $41 \%$ for the low- $\mathrm{NO}_{x}$ simulations but decreased from $26 \%$ to less than $5 \%$ in the high- $\mathrm{NO}_{x}$ simulations. This implied that the treatment of multigenerational aging in the SOM did not proportionately enhance the SOA mass concentrations from the different precursors but rather produced varying levels of enhancement for the different precursors that were further modified by the $\mathrm{NO}_{x}$ levels. This finding is of note because chemical transport models that have employed schemes such as the volatility basis set (VBS) have typically assumed that multigenerational aging has an approximately similar effect on SOA mass concentrations from different precursors, regardless of the $\mathrm{NO}_{x}$ levels, and one which does not significantly change the precursor contribution to SOA (Robinson et al., 2007). With the VBS, one may observe some differences with multigenerational aging from the use of different starting VBS distributions for SOA from different precursors.

The $\mathrm{SVOC}_{\max }$ simulations that assumed all POA (except marine POA) to be semi-volatile saw POA mass concentrations decrease by $36 \%$ compared to the Base simulations and by $56 \%$ compared to the Traditional simulations (not shown here but inferred from results in Fig. 3). The increase in SVOCs from the additional evaporation of POA mass resulted in about a 3 -fold increase in the aSSOA mass concentrations and a proportionate increase in the SVOC contribution to total SOA. Similar to the findings discussed in Sect. 3.3, only a fraction of the evaporated POA mass lost was regained as aS-SOA mass concentrations. For instance, when compared to the Traditional simulations, of the $2.9 / 3.3 \mu \mathrm{g} \mathrm{m}^{-3}$ of POA mass lost $0.32 / 0.22 \mu \mathrm{g} \mathrm{m}^{-3}$ was regained as aS-SOA reflecting a chemical conversion efficiency of $11 \% / 7 \%$ for the low-/high-NO $\mathrm{NO}_{x}$ simulations. These simulations predicted the maximum decrease in POA mass concentrations from treating all POA as semi-volatile and reactive, but the results still found POA to be $40 \%$ and $69 \%$ of the total OA in the low- and high- $\mathrm{NO}_{x}$ simulations respectively. Direct emissions of POA were still a sizeable fraction of the ambient OA and PM burden using the current state-of-the-science treatment.

Estimating IVOCs to be $20 \%$ of the NMOG emissions for all combustion sources and modeling the SOA formation from IVOCs using a $\mathrm{C}_{15}$ linear alkane - as modeled in the $\mathrm{IVOC}_{\max }$ simulations - resulted in an approximately 4-fold increase in the aI-SOA mass concentrations over the Base simulations. The increases were partly attributed to additional IVOC emissions from sources other than mobile and biomass burning (factor of 2.8 compared to IVOC emissions from the Base simulations) and partly to using a larger alkane $\left(\mathrm{C}_{15}\right.$ linear alkane) with a higher SOA mass yield to model SOA formation from IVOCs emitted by gasoline sources. Simulating SOA formation from IVOCs using an aromatic

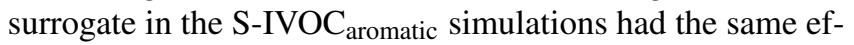
fect as the IVOC $_{\max }$ simulations and increased aI-SOA mass concentrations by a factor of 2.6 and 6.3 for the low- and high- $\mathrm{NO}_{x}$ simulations respectively. The aI-SOA mass concentrations were higher because aromatics for the same carbon number have a higher SOA mass yield than alkanes. The IVOC $_{\text {max }}$ and $S$-IVOC $C_{\text {aromatic }}$ simulations potentially present an upper-bound contribution of IVOCs to SOA formation, and in both these simulations they were $\sim 30 \%$ of the total SOA and a factor of $\sim 1.5-2$ larger than the aromatic VOC contribution. While the $\mathrm{IVOC}_{\max }$ and $\mathrm{S}-\mathrm{IVOC}_{\text {aromatic }}$ 
simulations dramatically increased the aI-SOA mass concentrations, these simulations only modestly increased the total OA mass concentrations over the low- and high- $\mathrm{NO}_{x}$ simulations (average increase of $10 \%$ ). Over the urban area, the OA mass concentrations in the $\mathrm{IVOC}_{\max }$ and $\mathrm{S}$-IVOC $\mathrm{Cromatic}_{\text {arom }}$ simulations were on average $10 \%-12 \%$ higher compared to the Base simulations (see Fig. S6). Updating the emissions profiles based on the work of May et al. (2014) had a negligible effect on the SOA mass concentrations and its precursor contribution, implying that the emissions profiles from more than a decade and a half ago may be sufficient to model the modern mobile source fleet. Finally, a lower-volatility (i.e., more realistic) POA in the $\mathrm{SVOC}_{\text {cooking }}$ simulations, informed by the measurements of Louvaris et al. (2017), resulted in a $20 \%$ increase in POA mass concentrations when compared to both the low- and high- $\mathrm{NO}_{x}$ Base simulations. POA mass concentrations in these low- and high- $\mathrm{NO}_{x}$ simulations accounted for approximately $55 \%$ and $85 \%$ of the OA respectively. The SOA mass concentrations between the $\mathrm{SVOC}_{\text {cooking }}$ and Base simulations remained the same.

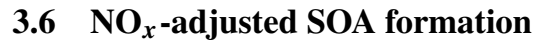

The SOM currently does not model the continuous evolution of SOA under varying $\mathrm{NO}_{x}$ concentrations. One of the challenges in modeling the $\mathrm{NO}_{x}$ influence on SOA formation has been in quantifying the branching of the VOC oxidation under low- and high- $\mathrm{NO}_{x}$ conditions. Most commonly used schemes in atmospheric models use the $\mathrm{NO}: \mathrm{HO}_{2}$ ratio to determine the initial branching of the precursor to form SOA via the low- or the high- $\mathrm{NO}_{x}$ pathway. However, this scheme depends on an accurate prediction of $\mathrm{NO}$ and $\mathrm{HO}_{2}$. To assess, at least qualitatively, the ability of the model to capture $\mathrm{NO}$ and $\mathrm{HO}_{2}$ concentrations, we compare 14-dayaveraged diurnal profiles from this work to those measured in Pasadena in 2010 during the CalNex campaign in Fig. S7. We found that the model predictions were within a factor of 2 for NO concentrations but were about a factor of 10 lower than the measured $\mathrm{HO}_{2}^{*}$ concentrations. We should note that the $\mathrm{HO}_{2}^{*}$ measurements included $\mathrm{HO}_{2}$ and a fraction of $\mathrm{RO}_{2}$ radicals, where $\mathrm{RO}_{2}$ radicals contributed to $\sim 30 \%$ of the $\mathrm{HO}_{2}^{*}$ measurements (Griffith et al., 2016). The inclusion of $\mathrm{RO}_{2}$ should not change the findings reported here. If the results from our modeling are representative of results from other atmospheric models that use SAPRC or other gas-phase chemical mechanisms, underestimating the $\mathrm{HO}_{2}$ concentrations may lead $\mathrm{NO}: \mathrm{HO}_{2}$-ratio-based schemes to overestimate the SOA formed via the high- $\mathrm{NO}_{x}$ pathway. Given this limitation and the fact that the SOM does not model the continuous evolution of SOA under varying $\mathrm{NO}_{x}$ concentrations, we attempted to model the $\mathrm{NO}_{x}$-dependent SOA formation using VOC : $\mathrm{NO}_{x}$ ratios and $\mathrm{NO}_{x}$ concentrations.

Four different methods - described in Eqs. (1) through (4) - were used to adjust the SOA mass concentrations from each individual precursor to account for the influence of

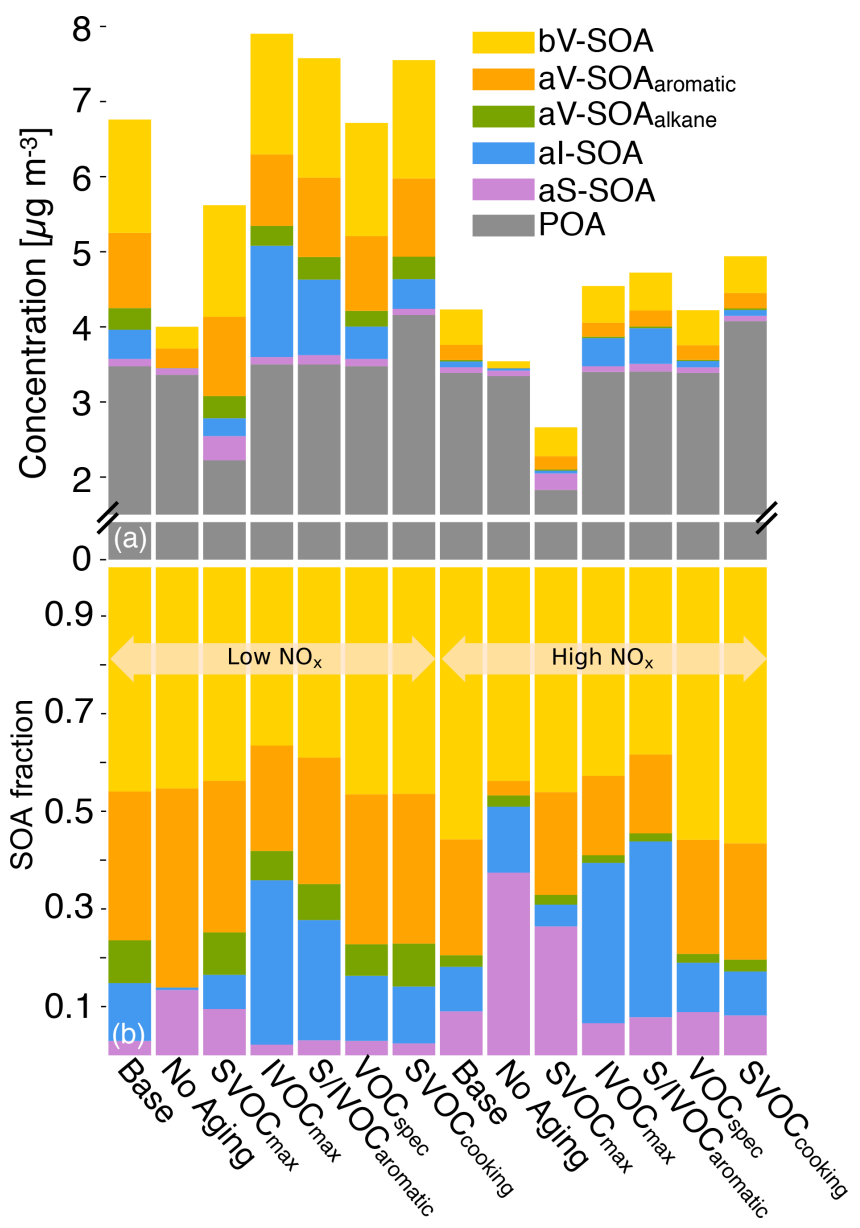

Figure 5. The 14-day-averaged model predictions of POA and SOA mass concentrations and precursor contributions from the sensitivity simulations. Panel (a) shows absolute concentrations and panel (b) shows precursor contributions. Model predictions from the lowand high- $\mathrm{NO}_{x}$ simulations are shown separately. Simulation legend: Base - Base case; No Aging - only models first generation chemistry in the SOM; $\mathrm{SVOC}_{\max }$ - all POA treated as semi-volatile; IVOC $_{\max }$ - all combustion sources assumed to have $20 \%$ IVOC emissions and a $\mathrm{C}_{15}$ SOA yield; $\mathrm{S}-\mathrm{IVOC}_{\text {aromatic }}-\mathrm{SVOCs}$ and IVOCs modeled as high-yield aromatic compounds; $\mathrm{VOC}_{\mathrm{spec}}-$ mobile source emissions profiles based on May et al. (2014); $\mathrm{SVOC}_{\text {cooking }}-\mathrm{POA}$ volatility distribution for food cooking sources based on the measurements of Louvaris et al. (2017). All simulations besides $\mathrm{SVOC}_{\text {cooking }}$ assumed food cooking POA to have the same volatility as biomass burning POA. More details about these simulation inputs can be found in Sect. 2.3.

$\mathrm{NO}_{x}$. To remind the reader, Eqs. (1) and (2) assume a linear and logarithmic dependence respectively between the SOA mass concentration and the VOC : $\mathrm{NO}_{x}$ ratio. Equations (3) and (4) assume a linear and logarithmic dependence respectively between the SOA mass concentration and the $\mathrm{NO}_{x}$ concentration. The adjusted SOA mass concentrations, referred to as $\mathrm{SOA}_{\mathrm{eff}}$, were summed to calculate the total SOA mass concentrations. Equation (2) produced the highest 


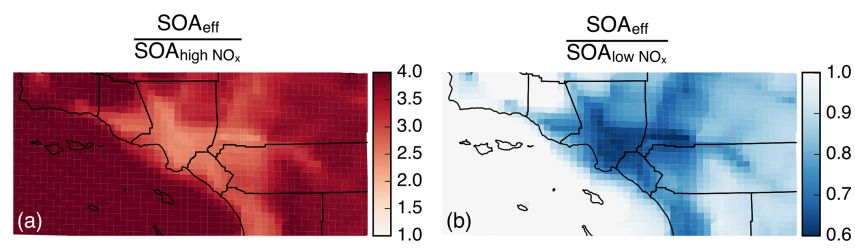

Figure 6. The 14-day-averaged ratio of the $\mathrm{SOA}_{\mathrm{eff}}$ mass concentration to the SOA mass concentration from the (a) high- $\mathrm{NO}_{x}$ and (b) low- $\mathrm{NO}_{x}$ Base simulations.

SOA mass concentrations while Eq. (3) produced the lowest SOA mass concentrations amongst the four equations. Scatter plots comparing the SOA mass concentrations calculated using Eq. (2) to those calculated using other equations, in Fig. S8, show that the SOA mass concentrations based on Eq. (2) were, on average, a factor of $1.27,3.19$, and 1.92 higher than those with Eqs. (1), (3), and (4) respectively. This meant that a calculation based on the VOC: $\mathrm{NO}_{x}$ ratio produced a stronger response of $\mathrm{NO}_{x}$ on SOA mass concentrations than the $\mathrm{NO}_{x}$ concentrations themselves. In the subsequent sections, where we evaluate the model predictions (Sect. 4) and predicted future changes in the OA burden (Sect. 5), we used the $\mathrm{SOA}_{\text {eff }}$ calculations based on Eq. (2) since they represented an upper-bound estimate of the $\mathrm{NO}_{x}$ effect on SOA mass concentrations. The validity of Eq. (2) needs to be examined in future work.

In Fig. 6, we plot the ratio of the total $\mathrm{SOA}_{\text {eff }}$ mass concentrations based on Eq. (2) to the total SOA mass concentrations from the (a) high- $\mathrm{NO}_{x}$ and (b) low- $\mathrm{NO}_{x}$ Base simulations. The $\mathrm{SOA}_{\text {eff }}$ mass concentrations were higher than the SOA mass concentrations predicted using the high- $\mathrm{NO}_{x}$ parameterizations, with an average factor of 2 increase in urban areas and a maximum factor of 4 increase in non-urban areas. This was because the model-predicted VOC: $\mathrm{NO}_{x}$ ratios in the urban areas were higher than the VOC : $\mathrm{NO}_{x}$ ratios produced in the high- $\mathrm{NO}_{x}$ chamber experiments, and based on Eq. (2) the SOA mass concentrations were adjusted upwards to include the SOA predicted using the low- $\mathrm{NO}_{x}$ parameterizations. The adjustments increased the SOA mass concentrations because the SOA mass concentrations from each precursor were universally higher with the use of the low$\mathrm{NO}_{x}$ parameterizations compared to the high- $\mathrm{NO}_{x}$ parameterizations. The $\mathrm{SOA}_{\text {eff }}$ mass concentrations were $30 \%-$ $40 \%$ lower than the SOA mass concentrations predicted using the low- $\mathrm{NO}_{x}$ parameterizations in urban areas, suggesting that the $\mathrm{SOA}_{\text {eff }}$ mass concentrations were approximately midway between the SOA predictions using the high- and low- $\mathrm{NO}_{x}$ parameterizations. In contrast, the $\mathrm{SOA}_{\text {eff }}$ mass concentrations were only marginally lower $(10 \%-20 \%)$ in the non-urban areas, implying that the $\mathrm{VOC}: \mathrm{NO}_{x}$ ratios in these regions were very similar to the VOC : $\mathrm{NO}_{x}$ ratios produced in the low- $\mathrm{NO}_{x}$ chamber experiments. In summary, a modest fraction of the SOA mass may be formed through the low- $\mathrm{NO}_{x}$ pathway in high- $\mathrm{NO}_{x}$ urban areas, which may result in substantial increases in the predicted SOA mass concentration when compared against predictions purely based on the use of high- $\mathrm{NO}_{x}$ parameterizations. This low- $\mathrm{NO}_{x}$ SOA will continue to increase in the future as $\mathrm{NO}_{x}$ concentrations are reduced in urban areas through controls on mobile sources. In contrast, only a small fraction of the SOA mass may be formed through the high- $\mathrm{NO}_{x}$ pathway in low$\mathrm{NO}_{x}$ non-urban areas, and the use of a low- $\mathrm{NO}_{x}$ parameterization in these regions will only marginally bias model predictions of SOA mass concentrations.

\section{Model evaluation}

Model predictions from the Base simulation were evaluated against gas-phase measurements of SOA precursors and particle-phase measurements of OA mass concentrations and composition. For the particle-phase measurements, we focused the model evaluation on predictions adjusted for the $\mathrm{NO}_{x}$ influence on SOA formation using Eq. (2) (logarithmic dependence on VOC : $\mathrm{NO}_{x}$ ratio).

\subsection{SOA precursors}

In Fig. 7a, we compare 14-day-averaged model predictions of aromatic concentrations for our 2005 episode against measured temporal trends in summer-averaged single-ring aromatic concentrations at three different sites in southern California (Los Angeles-North Main Street, RiversideRubidoux, and Long Beach) (SCAQMD, 2017); model predictions of aromatic concentrations are a sum of the benzene, ARO1, and ARO2 concentrations. On the same figure, we also plot model predictions of aromatic concentrations at Pasadena for our 2005 episode and measured single-ring aromatic concentrations made at the Pasadena ground site in 2010 as part of the CalNex campaign (Zhao et al., 2014). The summertime single-ring aromatic concentrations in southern California have decreased by a factor of 2 to 3 between 2000 and 2011 presumably from regulations that have targeted emissions from mobile sources. These reductions agreed well with reported temporal trends in carbon monoxide, nitrogen oxides, and non-methane organic compounds for Los Angeles over the same time period (Warneke et al., 2012; McDonald et al., 2013). Aromatic measurements at Pasadena in 2010 compared well with the 2010 measurements made $\sim 12 \mathrm{~km}$ southwest of Pasadena at the Los Angeles-North Main Street location, suggesting that the summer/campaign-averaged aromatic concentrations were spatially homogeneous over urban Los Angeles, and findings from the model-measurement comparison at a particular site could be generalized for the larger modeled domain. The model-measurement comparison for aromatics in 2005 was mixed. Concentrations were overpredicted by a factor of $\sim 1.5$ at the Los Angeles-North Main 


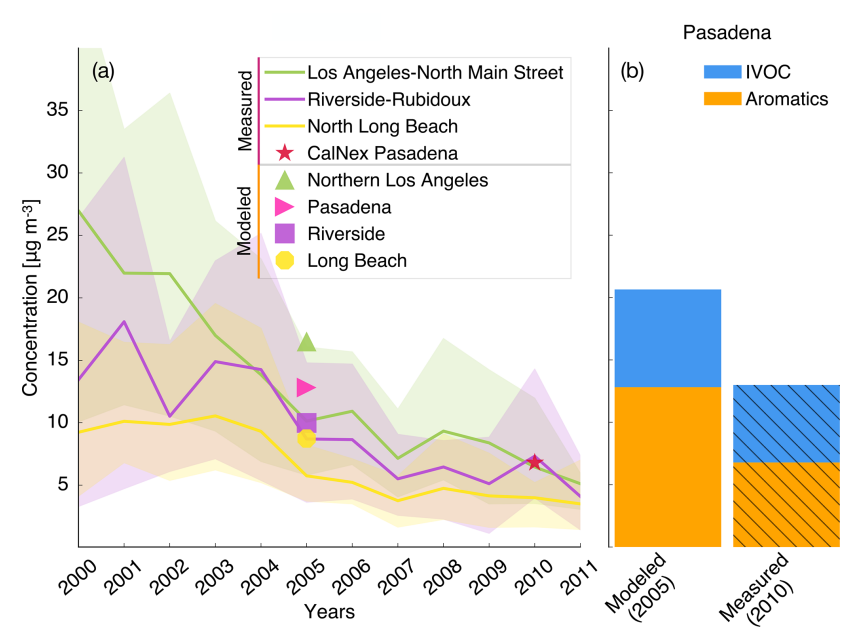

Figure 7. (a) Mass concentrations of single-ring aromatics in southern California at different sites between 2000 and 2011. Measurements show the temporal trend in the summertime mean (solid line) and 10th-90th percentile (bands) at Los Angeles, Riverside, and Long Beach from 2000 to 2011 (ARB, 2017) as well as the campaign-averaged measurement from CalNex at the Pasadena ground site in 2010 (Zhao et al., 2014). Model predictions show the 14-day-averaged concentration simulated in this work at four different sites (solid symbols) in 2005. (b) Mass concentrations of single-ring aromatics and IVOCs compared between the model predictions from 2005 (this work) and measurements in 2010 (Zhao et al., 2014).

Street and Long Beach sites but agreed well with measurements at Riverside-Rubidoux. The predictions might have been overestimated because we were using an older emissions inventory developed for the year 2000 but adapted for use for the year 2005 based on activity data (Hu et al., 2015). Another possibility for the overprediction was that the lumped model species ARO1 and ARO2 in SAPRC-11 also included emissions from oxygenated aromatic (e.g., phenols) and aromatic-like compounds (e.g., furans) while the measurements were limited to a handful of single-ring reduced aromatic compounds. Despite differences in the absolute concentrations, the model seemed to capture the measured spatial differences between the three sites; i.e. Los AngelesNorth Main Street $>$ Riverside-Rubidoux $>$ Long Beach.

In Fig. 7b, model predictions of aromatics and IVOCs in Pasadena in 2005 are compared against measurements made at the Pasadena ground site in 2010. The model predictions in Pasadena were calculated by averaging predictions from the grid cell that contained the Pasadena ground site and the grid cell immediately to the south. This was done because the ground site location was very close to the cell boundary to the south and the grid cell containing the Pasadena ground site included mountains to the north of Pasadena that tended to dilute the concentrations in that grid cell. The measurements in Fig. 7b included primary IVOCs but did not include the oxygenated IVOCs measured by Zhao et al. (2014) since the primary IVOCs, according to the authors, relate most closely to IVOC emissions from mobile sources. The IVOCs included in this work were mostly $(>95 \%)$ from mobile sources (see Fig. 1) and hence the comparison with primary IVOCs was appropriate. The model-predicted aromatic concentrations at Pasadena in 2005 were twice the measured aromatic concentrations at Pasadena in 2010. This 2005 (modeled) to 2010 (measured) ratio was slightly higher but still consistent with the measured 2005-to-2010 ratio in aromatic concentrations at the Los Angeles-North Main Street site (1.67). That the 2005 (modeled) to 2010 (measured) ratio for IVOCs in Pasadena was $\sim 1.0$ is some evidence that the model predictions of IVOCs might be underpredicted in 2005, assuming that the ambient IVOC-toaromatic ratio did not change between 2005 and 2010. The IVOC $_{\max }$ sensitivity simulation (the only sensitivity simulation that modeled an increase in IVOC emissions) predicted a 2005 (modeled) to 2010 (measured) ratio of 3.15 for IVOCs in Pasadena, which was closer to the measured aromatic concentrations ratios between 2005 and 2010 at the Los AngelesNorth Main Street site. This provides additional evidence for higher IVOC emissions to be included in the model. While this model-measurement comparison validates the aromatic SOA precursors and to some extent the mobile source IVOC SOA precursors, our model does not account for the oxygenated IVOCs that Zhao et al. (2014) measured and we recommend that future work investigate the sources, composition, and the SOA potential for these IVOCs.

\subsection{OA mass concentrations}

Scatter plots comparing model predictions of OA from the Base simulations to (a) CSN and (b) IMPROVE measurements in southern California are shown in Fig. 8a and b. Predictions from the low- and high- $\mathrm{NO}_{x}$ simulations are presented in grey while predictions accounting for the influence of $\mathrm{NO}_{x}$ are shown in color. The colors denote different sites and the site locations are shown in Fig. 8c. The modelmeasurement performance is also captured using statistical metrics of fractional bias, fractional error, and the coefficient of determination in Table 4. At all CSN sites, model predictions of OA that included SOA mass concentrations adjusted for the influence of $\mathrm{NO}_{x}$ were in between those predicted between the low- and high- $\mathrm{NO}_{x}$ simulations. As explained earlier, this was because the VOC: $\mathrm{NO}_{x}$ ratios at all these sites (see Fig. S9a) were always higher than those in the high- $\mathrm{NO}_{x}$ chamber experiments (see Table 2), and hence the SOA mass concentrations calculated using Eq. (2) were always higher than those predicted in the high- $\mathrm{NO}_{x}$ simulations. At all the CSN sites, correcting for $\mathrm{NO}_{x}$ improved model performance compared to the high- $\mathrm{NO}_{x}$ experiments but was still inferior compared to the predictions from the low- $\mathrm{NO}_{x}$ simulations (see Table 4). The mean predicted OA mass concentration across all the CSN sites was about $30 \%$ lower than the measurements (5.96 vs. $8.86 \mu \mathrm{g} \mathrm{m}^{-3}$ ). Model predictions of OA 

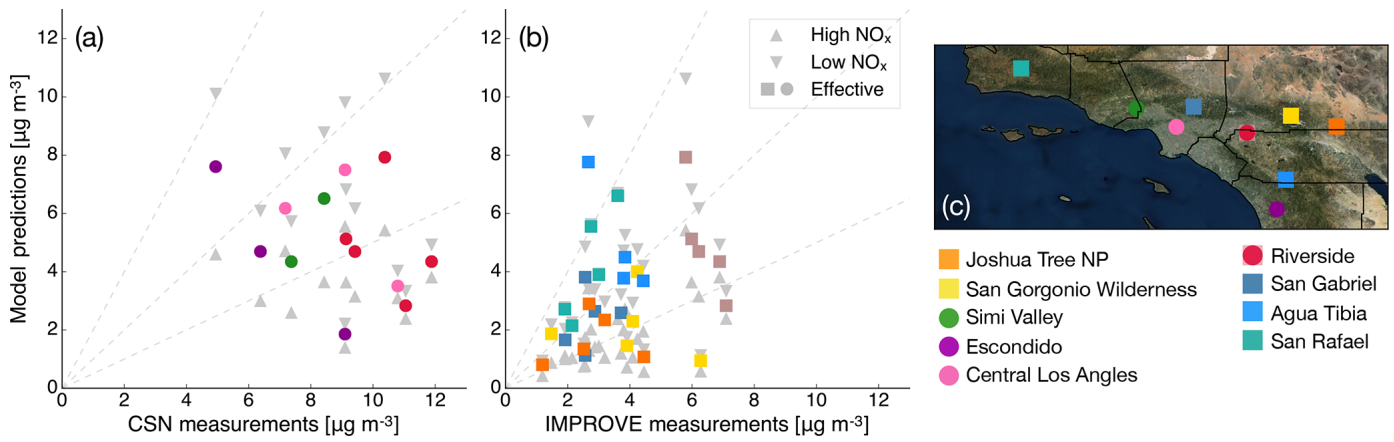

Figure 8. Model-measurement comparison for daily-averaged OA mass concentrations at (a) CSN and (b) IMPROVE sites in southern California. Panel (c) shows the geographic locations where the comparisons were made.

were very similar to those predicted in the low- $\mathrm{NO}_{x}$ simulations at the IMPROVE sites where the VOC : $\mathrm{NO}_{x}$ ratios were higher (e.g., San Rafael, green square). But, similar to the finding at the CSN sites, model predictions of OA were in between the predictions between the low- and high- $\mathrm{NO}_{x}$ simulations at the IMPROVE sites where the VOC : $\mathrm{NO}_{x}$ ratios were lower as a result of their proximity to urban areas (e.g., Agua Tibia, blue square; and Riverside, brown square). Accounting for $\mathrm{NO}_{x}$ seemed to improve the model performance at the IMPROVE sites when compared to predictions from the high- $\mathrm{NO}_{x}$ simulations and they were slightly inferior to those from the low- $\mathrm{NO}_{x}$ simulations (see Table 4). Of the 27 IMPROVE measurements available for comparison, 22 or $\sim 80 \%$ of the model predictions corrected for $\mathrm{NO}_{x}$ were within a factor of 2 of measurements with little bias (fractional bias $=-16.63 \%$ ). The model skill, captured by the $R^{2}$ values, for all model simulations at both the CSN and IMPROVE sites was quite poor but still slightly better than that found in earlier work for the southern California region with the CMAQ model (Baker et al., 2015). However, the model skill was much worse than that reported in earlier work with CMAQ (e.g., Murphy et al., 2017) and WRFChem (e.g., Ahmadov et al., 2012) over regions other than southern California, suggesting that there might be missing emissions sources and/or chemical pathways or meteorological considerations that contribute to the poor model skill in southern California.

Given the differences in the model-measurement comparison between the CSN (or urban) and IMPROVE (ru$\mathrm{ral} / \mathrm{remote}$ continental) sites, the underprediction at the CSN sites might be indicative of a missing urban source or pathway of OA formation. Recently, McDonald et al. (2018) found that volatile chemical products such as pesticides, coatings, cleaning agents, and personal care products may contribute substantially to IVOC emissions and account for more than half of the anthropogenic SOA formation in southern California. Our underprediction at urban sites might be evidence of missing SOA from volatile-chemical-productrelated IVOC emissions. However, it is also possible that the urban versus rural/remote continental difference is an artifact of how the SOM models the oxidation chemistry and/or accounts for the influence of vapor wall losses. Within the CSN and IMPROVE sites, we did not find the modelmeasurement comparison to vary systematically by location. The model-measurement comparison over all of California using the $24 \mathrm{~km}$ simulations produced a similar result (Fig. S10).

Model predictions of the $\mathrm{OA}: \triangle \mathrm{CO}$ diurnal profile and daytime OA versus $\mathrm{CO}$ (between 10:00 and 20:00 local time) are compared against measurements made at the Riverside site during the SOAR-1 campaign in Fig. 9a and b; SOA mass concentrations have been adjusted for the influence of $\mathrm{NO}_{x}$ using Eq. (2). The $\Delta \mathrm{CO}$ for the measurements was calculated by assuming a background concentration of $105 \mathrm{ppbv}$ (Hayes et al., 2013) while the $\Delta \mathrm{CO}$ for the model predictions was calculated by using the model-predicted background concentration of CO over the ocean to the west of Los Angeles. This model-measurement comparison was not completely coincident in time since the model results were between 20 July and 2 August while the SOAR-1 campaign spanned from 15 July to 15 August. The measurements did not point to any substantial differences in results between the coincident and non-coincident time, and hence we did not anticipate any issues in our comparisons here. The model predictions were able to capture the general trends in the measured diurnal profile in Fig. 9a with low ratios during the night, high ratios attributed to photochemistry in the mid-afternoon, and a peak between 13:00 and 14:00 (local time). However, the modeled OA : $\triangle \mathrm{CO}$ ratios at all times in the diurnal profile in Fig. 9a and the slope of the OA : CO ratios in Fig. 9b were approximately a factor of 2 to 3 lower than the measured ratios, indicating a significant underprediction of urban SOA, which was consistent with the much higher POA / SOA ratios predicted by the model compared to the observations, as discussed above. This underprediction cannot be blamed on the model grid resolution since a ratio with $\mathrm{CO}$ should to first order account for the influence of dilution in the grid cell. Cappa et al. (2016) showed much better model performance than this work when they assumed a non-volatile POA and SOA formed under low- $\mathrm{NO}_{x}$ conditions. In this work, 
Table 4. Statistical metrics of averages, fractional bias, fractional error, and $R^{2}$ for the model-measurement comparison in southern California.

\begin{tabular}{|c|c|c|c|c|c|c|c|c|c|c|}
\hline \multirow[t]{2}{*}{ Simulation } & \multicolumn{5}{|c|}{$\mathrm{CSN}$} & \multicolumn{5}{|c|}{ IMPROVE } \\
\hline & $\begin{array}{r}\text { Measured } \\
\text { average } \\
\left(\mu \mathrm{g} \mathrm{m}^{-3}\right)\end{array}$ & $\begin{array}{r}\text { Modeled } \\
\text { average } \\
\left(\mu \mathrm{g} \mathrm{m}^{-3}\right)\end{array}$ & $\begin{array}{r}\text { Fractional } \\
\text { bias }\end{array}$ & $\begin{array}{r}\text { Fractional } \\
\text { error }\end{array}$ & $R^{2}$ & $\begin{array}{r}\text { Measured } \\
\text { average } \\
\left(\mu \mathrm{g} \mathrm{m}^{-3}\right)\end{array}$ & $\begin{array}{r}\text { Modeled } \\
\text { average } \\
\left(\mu \mathrm{g} \mathrm{m}^{-3}\right)\end{array}$ & $\begin{array}{r}\text { Fractional } \\
\text { bias }\end{array}$ & $\begin{array}{r}\text { Fractional } \\
\text { error }\end{array}$ & $R^{2}$ \\
\hline Base - low $\mathrm{NO}_{x}$ & 8.86 & 7.96 & $-31.5 \%$ & $46.0 \%$ & 0.16 & 3.72 & 4.87 & $-1.38 \%$ & $41.8 \%$ & 0.116 \\
\hline Base - effective & 8.86 & 5.96 & $-53.4 \%$ & $49.2 \%$ & 0.13 & 3.72 & 4.02 & $-16.6 \%$ & $44.8 \%$ & 0.079 \\
\hline Base - high $\mathrm{NO}_{x}$ & 8.86 & 3.97 & $-83.1 \%$ & $83.1 \%$ & 0.013 & 3.72 & 2.00 & $-74.1 \%$ & $75.9 \%$ & 0.317 \\
\hline
\end{tabular}

despite forming additional SOA from SVOCs and IVOCs, the evaporation of the POA mass and an SOA estimate adjusted for $\mathrm{NO}_{x}$ meant that the model performance was worse in comparison to Cappa et al. (2016). The sensitivity simulations of IVOC $_{\max }$ and S-IVOC aromatic produced slightly higher OA mass concentrations $(\sim 10 \%-15 \%)$ compared to the Base simulations but not dramatically different to influence the comparison in Fig. 9a and b. As mentioned earlier, SOA formation from IVOC emissions from volatile chemical products, or other future improvements in the SOM, has the potential to reduce the model underprediction at Riverside during the SOAR-1 campaign.

\subsection{POA and SOA mass concentrations}

The 14-day-averaged results predicted POA and SOA mass concentrations of 3.4 and $2.2 \mu \mathrm{g} \mathrm{m}^{-3}$ and an approximate 60 : 40 POA-SOA split at Riverside. Docherty et al. (2011) estimated average POA and SOA mass concentrations of 1.9 and $7.0 \mu \mathrm{g} \mathrm{m}^{-3}$ and a POA-SOA split of $20: 80$ at Riverside during the SOAR-1 campaign. On an absolute basis, model predictions of POA mass concentrations were overpredicted by $\sim 80 \%$. A sensitivity simulation that turned sea spray emissions off suggested that the 14-day-averaged marine POA mass concentrations at Riverside were $\sim 0.8 \mu \mathrm{g} \mathrm{m}{ }^{-3}$, which are very likely to be overestimated (Hayes et al., 2013). If the emissions of marine POA were updated to align better with the observations and in the limiting case where the marine POA mass concentrations at Riverside were negligible, model-predicted POA mass concentrations at Riverside $\left(3.4-0.8=2.6 \mu \mathrm{g} \mathrm{m}^{-3}\right)$ would compare well with the measured values $\left(1.9 \mathrm{\mu g} \mathrm{m}^{-3}\right)$. As the POA mass concentrations in the $\mathrm{SVOC}_{\text {cooking }}$ simulations increased and the SOA mass concentrations remained the same compared to the Base simulations, a low-volatility and more realistic treatment of the POA from food cooking sources increased the discrepancy in the modeled and measured POA : SOA ratio at Riverside. It is also possible that the model might be overpredicting POA because we only considered POA from certain sources (gasoline and diesel use, woodsmoke, and food cooking) to be semi-volatile.
Figure 1 shows that more than half of the partitioned POA (that excludes marine POA) in southern California belonged to other sources (e.g., road and construction dust) and this POA was treated as non-volatile in the Base simulations. Model predictions from the $\mathrm{SVOC}_{\max }$ simulations that treated all POA except marine POA as semi-volatile predicted a 14-day-averaged POA mass concentration of $2.1 \mathrm{\mu g} \mathrm{m}^{-3}$, which was much closer to the measured value of $1.9 \mathrm{\mu g} \mathrm{m}^{-3}$. This suggests that all POA, regardless of source, might be semi-volatile and could be modeled so in atmospheric models. While these results are in better agreement with measurements, $\mathrm{PM}_{2.5}$ from road and construction dust sources is not created in a high-temperature process followed by rapid cooling and so it is unknown whether the POA portion in it would evaporate with atmospheric dilution. We also compared the hydrocarbon-like OA estimate from the measurements, which was more representative of POA from mobile sources, against model predictions of POA from mobile sources. We did not model POA from mobile sources separately, but if we assumed that mobile sources only accounted for about a quarter of the partitioned POA mass in southern California (based on Fig. 1), our estimated Base model predictions of POA mass concentrations from mobile sources of $0.85 \mu \mathrm{g} \mathrm{m}^{-3}(=3.4 \times 0.25)$ would compare reasonably with the measured HOA mass concentrations of $1.20 \mathrm{\mu g} \mathrm{m}^{-3}$.

On an absolute basis, SOA mass concentrations were underpredicted by a factor of 3 compared to measurements. Based on the discussion in the previous paragraph, if we added the non-mobile source POA to SOA, the net SOA mass concentration $\left(3.4 \times 0.75+2.2=4.75 \mu \mathrm{g} \mathrm{m}^{-3}\right)$ was still $33 \%$ lower than the measured value. The SOA mass concentrations in the $\mathrm{IVOC}_{\max }$ simulations - sensitivity simulations that modeled a fixed IVOC : NMOG ratio of $20 \%$ for all sources except biogenic sources, assumed IVOCs formed SOA similar to a $\mathrm{C}_{15}$ linear alkane, and which produced the maximum SOA mass concentrations amongst all the simulations - were $33 \%$ higher than those in the Base simulation but still $\sim 60 \%$ lower than the measured SOA mass concentration of $7 \mu \mathrm{g} \mathrm{m}^{-3}$. A combination of the two, i.e., adding the non-mobile source POA to the SOA formation in the $\mathrm{IVOC}_{\max }$ simulations, resulted in a net SOA mass concentration that was only $22 \%$ lower than the measured 

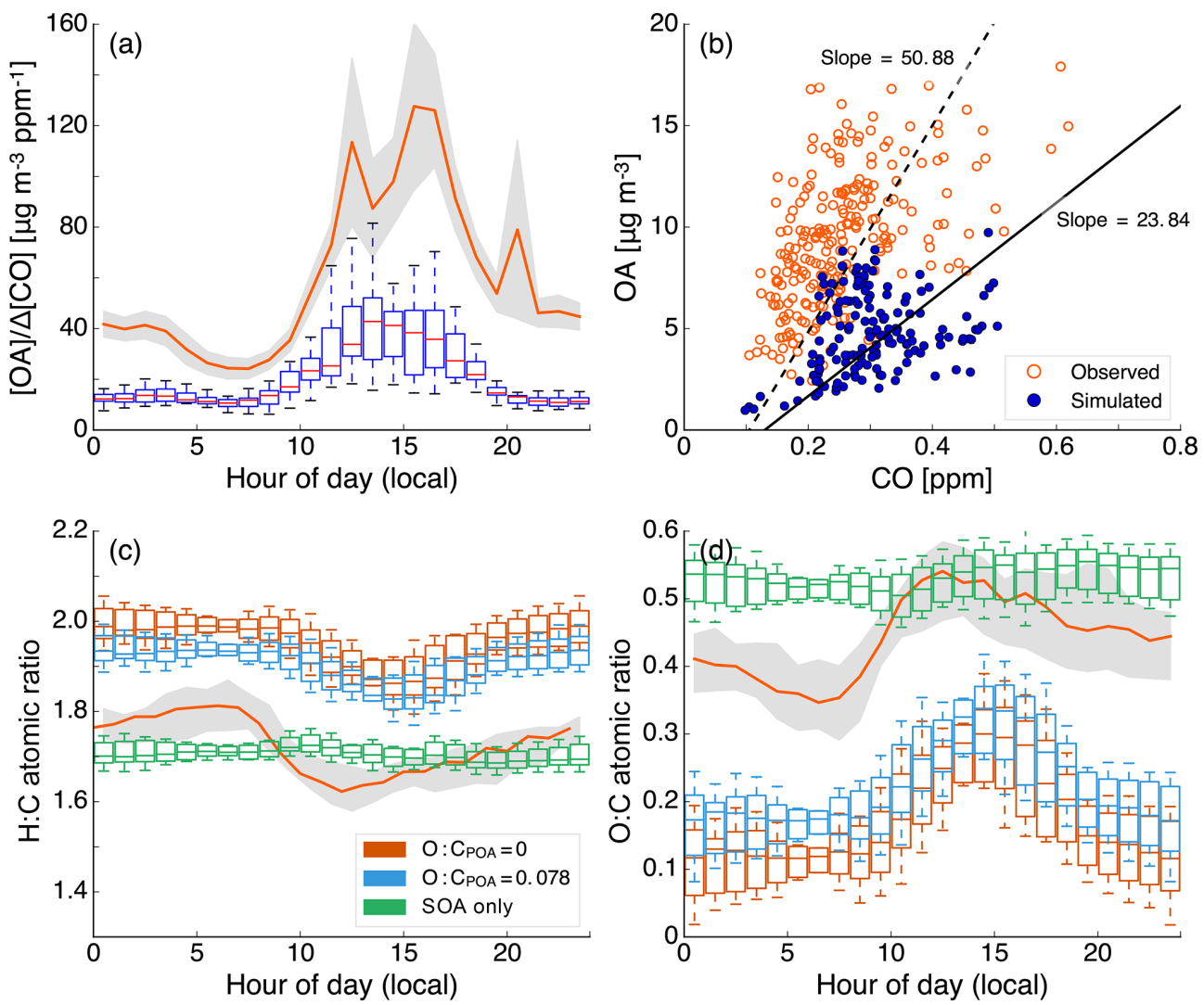

Figure 9. (a) Diurnal profile of the modeled and measured OA / $\triangle \mathrm{CO}$ ratios at Riverside, CA. The box plots capture the 10th, 25th, 50th, 75th, and 90th percentile in model predictions over the simulated episode, while the gray bands and solid orange line represent the 10th and 90th percentile and median of the measured data. (b) Modeled and measured OA mass concentrations plotted against CO concentrations between 10:00 and 20:00 local time. The solid and dashed black lines represent lines fitted to the modeled and measured data by forcing the $x$ intercept to be the corresponding modeled and measured background CO concentration. Diurnal profiles of the modeled and measured (c) $\mathrm{H}: \mathrm{C}$ and (d) O : C ratios of the OA (corrected as per Canagaratna et al., 2015). The three different predictions show results from the Base simulations for OA assuming no change, the POA O : C fixed to 0.078 based on the measurements of Docherty et al. (2011), and no POA.

SOA value. Since the $\mathrm{IVOC}_{\max }$ simulations produced ambient IVOC concentrations that were more in line with the measurement trends (see Sect. 4.1), it is likely that the $\mathrm{IVOC}_{\max }$ simulations were better in predicting IVOC concentrations and their contribution to SOA. However, there are no bottomup (i.e., source) or top-down (i.e., atmospheric) data to directly constrain the emissions of and SOA formation from IVOCs in the $\mathrm{IVOC}_{\max }$ simulations, and hence this finding provides motivation for more detailed studies of IVOCs in the future.

\subsection{OA elemental composition}

The SOM tracks the carbon and oxygen numbers for the OA species, and hence we were able to compare model predictions of the diurnal profiles for the $\mathrm{OA} \mathrm{H}: \mathrm{C}$ and $\mathrm{O}: \mathrm{C}$ ratios to measurements made at the Riverside site during the SOAR-1 campaign. The comparisons are shown in Fig. 9c and d. For the Base simulations (shown as orange box plots), model predictions of $\mathrm{H}: \mathrm{C}$ were significantly overpredicted and those for $\mathrm{O}: \mathrm{C}$ were significantly underpredicted although the predictions did capture dips in the $\mathrm{H}: \mathrm{C}$ and the peaks in the $\mathrm{O}: \mathrm{C}$ ratios in the mid-afternoon, coincident with peak photochemical activity. The model predictions did not capture the slight increase in $\mathrm{H}: \mathrm{C}$ and the decrease in $\mathrm{O}: \mathrm{C}$ in the early morning attributed to emissions from rushhour traffic. The high $\mathrm{H}: \mathrm{C}$ and low $\mathrm{O}: \mathrm{C}$ predictions were a result of OA being dominated by POA $(\sim 60 \%)$, which in this work was modeled as a hydrocarbon distribution that had an $\mathrm{H}$ : C slightly larger than 2.0 and an $\mathrm{O}: \mathrm{C}$ of 0 . Docherty et al. (2011) found that POA had a campaign-averaged $\mathrm{H}: \mathrm{C}$ of 1.92 and an $\mathrm{O}: \mathrm{C}$ of 0.078 . If the POA $\mathrm{O}: \mathrm{C}$ ratios were fixed to the values estimated by Docherty et al. (2011), model predictions (shown as blue box plots) improved - as shown in Fig. 9c and d - but still over- and underpredicted the $\mathrm{H}$ : C and $\mathrm{O}: \mathrm{C}$, respectively; since SOM only tracks carbon and oxygen numbers for an organic species and determines the hydrogen number based on the remaining valence, specifying the $\mathrm{O}: \mathrm{C}$ dictates the $\mathrm{H}: \mathrm{C}$. To assess the ability of the model to predict the elemental composition of SOA, we plot 
the diurnal profile of $\mathrm{H}: \mathrm{C}$ and $\mathrm{O}: \mathrm{C}$ of the SOA in Fig. 9c and $\mathrm{d}$. Model predictions of SOA $\mathrm{H}: \mathrm{C}$ and $\mathrm{O}: \mathrm{C}$ (shown as green box plots) compared well with the measured range of values but did not reproduce the diurnal changes. Docherty et al. (2011) argued that the $\mathrm{H}: \mathrm{C}$ and $\mathrm{O}: \mathrm{C}$ of $\mathrm{OA}$ at Riverside was mostly controlled by the SOA composition, which did not change dramatically during the day, and was modified by POA at certain times when POA emissions dominated over SOA production (e.g., nights, rush-hour traffic). This suggests that if absolute predictions of the SOA mass concentrations and the POA-SOA splits were improved, our model would be able to predict both the magnitude and diurnal changes in $\mathrm{OA} \mathrm{H}: \mathrm{C}$ and $\mathrm{O}: \mathrm{C}$ ratios. We found that the SOA $\mathrm{H}: \mathrm{C}$ and $\mathrm{O}: \mathrm{C}$ ratio predictions did not vary significantly and produced similarly flat diurnal profiles across a subset of sensitivity simulations performed (Fig. S11), suggesting that the modeled elemental composition of SOA was not very sensitive to the distribution of precursor contributions to SOA.

\section{Summary and discussion}

Organic aerosol (OA) is an important contributor to urban fine particle pollution yet remains one of its most uncertain components. In this work, we updated the organic aerosol treatment in the UCD/CIT chemical transport model to include a semi-volatile and reactive treatment of POA, emissions and SOA formation from IVOCs, the $\mathrm{NO}_{x}$ influence on SOA formation, and SOA parameterizations for SVOCs and IVOCs that were corrected for vapor wall loss artifacts during chamber experiments. All updates were implemented in the statistical oxidation model (SOM), which simulates the multigenerational aging and gas-particle partitioning of organic aerosol and is embedded in the UCD/CIT model (Cappa et al., 2016; Jathar et al., 2015, 2016). POA, SVOC, and IVOC updates were based on an interpretation of a comprehensive set of source measurements. The influence of $\mathrm{NO}_{x}$ on SOA formation was estimated offline using methods based on the VOC : $\mathrm{NO}_{x}$ ratios and $\mathrm{NO}_{x}$ concentrations.

Despite treating the POA from gasoline, diesel, biomass burning, and food cooking sources as semi-volatile, the updated model only predicted a $30 \%-50 \%$ decrease in POA mass concentrations in the urban airshed even when the volatility data used to simulate POA projected a much larger decrease ( $45 \%$ to $80 \%$ ). The primary reason for the weaker response was that a large fraction of the POA mass came from sources other than those modeled as semi-volatile (e.g., road and construction dust, marine). When all POA, except for marine POA, was modeled as semi-volatile, more than $60 \%$ of the POA mass evaporated and the POA mass concentrations under this scenario compared well with measurements made in Riverside, CA, as part of the SOAR-1 field campaign. While this sensitivity analysis was informative, it is unlikely that the POA from sources such as road and con- struction dust is semi-volatile, and recent measurements suggest that POA from food cooking sources has much lower volatility than assumed in the Base simulations in this work. These findings indicate that model predictions continue to overestimate POA relative to measured concentrations. Sea spray emissions accounted for a quarter of the POA mass concentrations in the urban airshed, but more recent observations suggest that the sea spray emissions or the organic fraction attributed to the sea spray emissions might be overestimated (Hayes et al., 2013). This needs to be examined in future applications of the UCD/CIT model. Atmospheric oxidation of the evaporated POA vapors or SVOCs did not contribute significantly to the SOA burden $\left(<0.1 \mu \mathrm{g} \mathrm{m}^{-3}\right)$, even after accounting for the influence of vapor wall loss artifacts, since the timescales for SOA production appeared to be longer than the timescales for transport out of the urban airshed.

We found IVOCs to be more important than SVOCs but less important than traditional VOCs such as single-ring aromatics and biogenics in forming SOA. IVOCs accounted for less than $0.5 \mu \mathrm{g} \mathrm{m}^{-3}$ of SOA while single-ring aromatics and biogenics each contributed to approximately $1 \mu \mathrm{g} \mathrm{m}^{-3}$ in the Base simulations. The IVOC contribution to SOA was smaller than that for aromatics partly because IVOC SOA was relatively less sensitive to corrections of vapor wall loss artifacts in chamber experiments. Another reason for the small IVOC contribution to SOA was that we only considered IVOC emissions from gasoline, diesel, and biomass burning. On analyzing trends in SOA precursor concentrations in southern California, the modeled IVOC concentrations in this scenario appeared to be underpredicted by a factor of $\sim 2$. Allowing all sources that emit non-methane organic gases (NMOG) to emit IVOCs (using an IVOC: NMOG ratio of 0.2 ) and form SOA similar to a $\mathrm{C}_{15}$ linear alkane seemed to increase the IVOC contribution to SOA ( $1 / 3$ of total SOA) and produced better comparisons against ambient measurements of IVOC concentrations, OA composition, and SOA mass concentrations. This might be indicative of missing IVOC emissions in the model. These missing emissions might be from volatile chemical products such as pesticides, coatings, cleaning agents, and personal care products, which have been found to contribute substantially to urban SOA burdens (McDonald et al., 2018). It is also likely that the missing IVOC emissions are from sources considered in this work (i.e., gasoline, diesel, and biomass burning sources) but were not accounted for in the emissions inventories because they have been shown to be very easily lost to sampling tubes (Pagonis et al., 2017). The IVOCs in this work were modeled using a linear alkane surrogate despite recent evidence that IVOCs in combustion emissions are a mixture of branched and cyclic alkanes, aromatics, and oxygenated compounds with very few linear alkanes (Koss et al., 2018; Zhao et al., 2016, 2017). A more chemically appropriate representation of the IVOCs would not have substantially changed the findings in this work since the linear 
alkane surrogates were chosen to reproduce the SOA formation in chamber experiments performed on combustion emissions. However, future work should incorporate the more detailed speciation available to model the emissions and SOA formation from IVOCs.

Loss of vapors to the Teflon walls has been shown to significantly bias SOA formation in environmental chamber experiments (Krechmer et al., 2016; Zhao et al., 2014). Cappa et al. (2016) studied the influence of vapor wall loss artifacts on ambient SOA mass concentrations from VOC precursors. In this work, we extended the work of Cappa et al. (2016) by considering additional precursors of SOA, i.e., S/IVOCs. Correcting for vapor wall loss artifacts seemed to increase SOA mass concentrations for all precursors but the enhancement varied by precursor. With a few exceptions, the SOA enhancements correlated with carbon number where larger carbon number precursors had lower enhancements and vice versa. The reason for this inverse relationship was that larger precursors and their oxidation products have shorter chemical lifetimes and undergo fewer chemical reactions to form SOA, which made them less susceptible to being lost to the chamber walls. Recent work suggests that the vapor wall loss rates to the Teflon wall might be 2 or more times larger than the rates used in this work to develop the SOM parameters (Huang et al., 2018; Krechmer et al., 2016). The use of these faster rates will tend to increase the model-predicted SOA mass concentrations and help explain the underpredictions with ambient measurements.

The emissions inputs and chemical treatment for OA was varied substantially in the sensitivity simulations performed in this work. Yet, the simulations seemed to change the OA by less than a factor of 2, suggesting that the model framework, except for the treatment of $\mathrm{NO}_{x}$, was generally reasonable in constraining the total OA mass concentrations in southern California. The total SOA enhancement was modified by the $\mathrm{NO}_{x}$ level where low- $\mathrm{NO}_{x}$ regions might see higher enhancements compared to high- $\mathrm{NO}_{x}$ regions. In southern California where urban SOA mass concentrations might be higher than rural/remote continental SOA mass concentrations, the $\mathrm{NO}_{x}$-mediated enhancement will tend to reduce the spatial gradients in SOA mass concentrations and make $\mathrm{SOA}$ a regional pollutant like $\mathrm{O}_{3}$. Accounting for the influence of $\mathrm{NO}_{x}$ seemed to improve OA model performance against routine measurements in rural/remote environments (i.e., Interagency Monitoring of Protected Visual Environments network) where OA model predictions were within a factor of 2 with very little bias (e.g., fractional bias of $-16.6 \%)$. However, model predictions of $\mathrm{OA}$ at routine monitoring sites in urban environments (i.e., Chemical Speciation Network) and at the Riverside site during the SOAR-1 field campaign were still underpredicted by at least a factor of 2 (e.g., fractional bias of -49.2\%). This suggested a missing emissions or chemical source of OA in urban areas.

The future OA burden in southern California will depend not only on reductions in POA and SOA precursor emissions

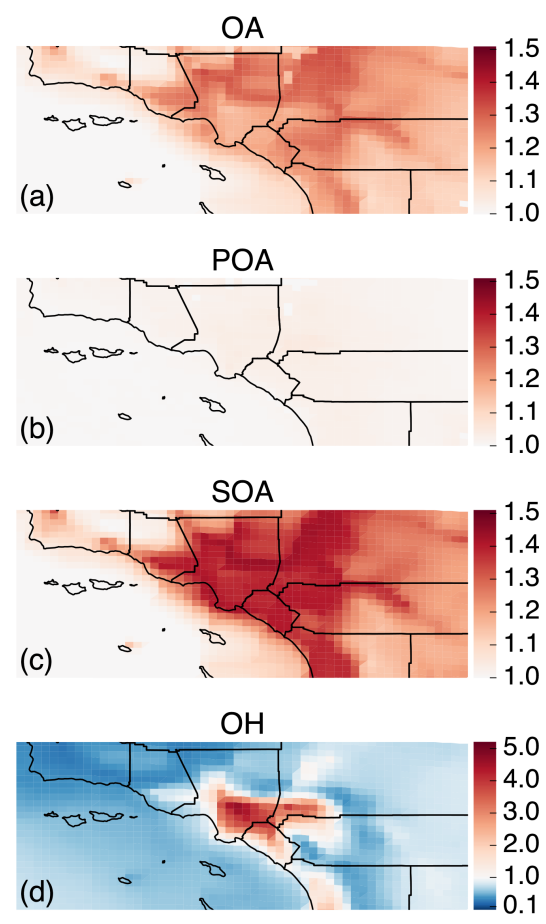

Figure 10. Ratios of 14-day-averaged model predictions of (a) OA, (b) POA, (c) SOA, and (d) OH from 2035 to those from 2005. The 2035 simulations were performed with 2005 meteorological inputs but scaling the anthropogenic emissions for $\mathrm{CO}, \mathrm{NO}_{x}, \mathrm{VOC}, \mathrm{PM}_{2.5}$, $\mathrm{SO}_{2}$, and $\mathrm{NH}_{3}$ based on changes projected by the California Emission Projections and Analysis Model (CARB, 2018).

but also on changes in oxidant concentrations and VOC: $\mathrm{NO}_{x}$ ratios. We used the Base model to simulate the same time period, 20 July to 2 August, for the year 2035 to determine how emissions reductions and atmospheric conditions may change in a future year to influence ambient OA-POASOA mass concentrations. The same meteorology and environmental conditions were assumed, with the understanding that climatological changes in the future may alter the findings presented here. Emissions reductions in $\mathrm{CO}, \mathrm{NO}_{x}$, VOC, $\mathrm{PM}_{2.5}, \mathrm{SO}_{2}$, and $\mathrm{NH}_{3}$ were informed by net reductions in statewide emissions between 2005 and 2035 as projected by the California Emission Projections and Analysis Model (CARB, 2018). The 2005 inventory was scaled based on these emissions reductions for anthropogenic sources but the biogenic emissions and VOC emissions profiles were kept the same. We did not resolve the emissions reductions in these pollutants by source or by region since the goal was to examine the general trend in the OA-POA-SOA system and not to predict future air quality; heterogeneity in the reduction in pollutant emissions by source and geography may alter the results. Statewide emissions reductions in $\mathrm{CO}, \mathrm{NO}_{x}$, and VOC of $78 \%, 83 \%$, and $33 \%$ resulted in approximately $50 \%, 75 \%, 75 \%$, and $30 \%$ reductions in ambient concentrations of $\mathrm{CO}, \mathrm{NO}, \mathrm{NO}_{2}$, and $\mathrm{VOC}$ in the urban airshed (Fig. S12 plots the ratio of $\mathrm{CO}, \mathrm{NO}, \mathrm{NO}_{2}$, and VOC con- 
centrations in 2035 to those in 2005). Here, VOC is the sum of all organic species tracked in the SAPRC-11 gas-phase chemical mechanism (excludes methane). Since the $\mathrm{NO}_{x}$ reduction was much more dramatic than that for VOCs, the VOC : $\mathrm{NO}_{x}$ ratio in the urban airshed increased from $\sim 1$ to $\sim 5$ between 2005 and 2035, which was in line with recent modeled estimates by Fujita et al. (2016).

We plot the ratio of the mass concentrations for OA, POA, and SOA in 2035 to those in 2005 in Fig. 10a, b, and c respectively. SOA mass concentrations have been adjusted for the influence of $\mathrm{NO}_{x}$ using Eq. (2). POA mass concentrations in the urban airshed in 2035 were slightly higher $(\sim 5 \%)$ than those in 2005 primarily because $\mathrm{PM}_{2.5}$ emissions were higher in 2035 compared to 2005; according to CEPAM (California Emission Projections and Analysis Model), increases in $\mathrm{PM}_{2.5}$ emissions were mostly from increases in area source emissions and not mobile source emissions. Surprisingly, SOA mass concentrations in the urban airshed were $30 \%-40 \%$ higher in 2035 compared to 2005 despite a $30 \%$ reduction in VOC emissions and concentrations. Some of the increase in the SOA mass concentrations was from a shifting VOC : $\mathrm{NO}_{x}$ ratio that produced more $\mathrm{SOA}$ via the low- $\mathrm{NO}_{x}$ pathway. However, the primary reason for the SOA increase was that $\mathrm{OH}$ concentrations in the urban area had increased by a factor of 2 to 4 (see Fig. 10d) and had reacted more of the SOA precursors. The $\mathrm{OH}$ concentrations were presumably higher in 2035 because lower $\mathrm{NO}_{x}$ emissions resulted in a higher $\mathrm{OH}$ lifetime since the $\mathrm{NO}_{2}+\mathrm{OH}$ reaction is the primary sink for $\mathrm{OH}$ in polluted environments (Jacob, 1999), including the Los Angeles area (Griffith et al., 2016). These findings suggest that the SOA and OA mass concentrations may not necessarily respond linearly to reductions in VOC and $\mathrm{NO}_{x}$ emissions in the future but rather will be strongly influenced by the changes in chemical regime. Similarly, Praske et al. (2018) argue that dramatic reductions in $\mathrm{NO}_{x}$ emissions and concentrations in urban environments may increasingly lead to SOA formation through autooxidation pathways and alter the rate and quantity of SOA formed. Hence, attention needs to be paid to appropriately simulate the chemical regime (e.g., oxidant concentrations, VOC : $\mathrm{NO}_{x}$ ratios, autooxidation reactions) if we are to accurately simulate the SOA burden in urban environments in the future.

Data availability. All measurements and select model predictions in this work are archived at https://doi.org/10.25675/10217/194377 (Akherati et al., 2019). 


\title{
Appendix A: Nomenclature
}

\author{
OA Organic aerosol \\ POA Primary organic aerosol or direct emissions of organic aerosol \\ SOA Secondary organic aerosol or organic aerosol formed in the atmosphere \\ VOC Volatile organic compound \\ NMOG Non-methane organic gas \\ SVOC Semi-volatile organic compound \\ IVOC Intermediate-volatility organic compound \\ HOA Hydrocarbon-like organic aerosol measured by the aerosol mass spectrometer \\ OOA Oxygenated organic aerosol measured by the aerosol mass spectrometer \\ aV-SOA Anthropogenic SOA formed from VOC oxidation \\ bV-SOA Biogenic SOA formed from VOC oxidation \\ aS-SOA Anthropogenic SOA formed from SVOC oxidation \\ aI-SOA Anthropogenic SOA formed from IVOC oxidation
}


Supplement. The supplement related to this article is available online at: https://doi.org/10.5194/acp-19-4561-2019-supplement.

Author contributions. SHJ and AA developed the model and designed the configurations of the numerical simulations with some help from MJK. AA performed the numerical simulations and postprocessed and analyzed the model outputs. AA and SHJ wrote the paper with contributions from all co-authors.

Competing interests. The authors declare that they have no conflict of interest.

Acknowledgements. We thank Nehzat Motallebi for sharing the VOC data gathered by the California Air Resources Board in southern California. Ali Akherati and Shantanu H. Jathar were partially supported by the National Oceanic and Atmospheric Administration (NA17OAR4310003). Jose L. Jimenez was supported by the Environmental Protection Agency (EPA) STAR program (83587701-0). EPA has not reviewed this manuscript and thus no endorsement should be inferred. Stephen M. Griffith, Sebastien Dusanter, Philip S. Stevens, and Christopher D. Cappa were supported by the National Science Foundation (AGS-0612738, AGS1104880, and AGS-1523500).

Review statement. This paper was edited by Robert Harley and reviewed by three anonymous referees.

\section{References}

Ahmadov, R., McKeen, S. A., Robinson, A. L., Bahreini, R., Middlebrook, A. M., de Gouw, J. A., Meagher, J., Hsie, E.Y., Edgerton, E., Shaw, S., and Trainer, M.: A volatility basis set model for summertime secondary organic aerosols over the eastern United States in 2006, J. Geophys. Res., 117, D06301, https://doi.org/10.1029/2011JD016831, 2012.

Akherati, A., Cappa, C. D., Kleeman, M. J., Docherty, K. S., Jimenez, J. L., Griffith, S. M., Dusanter, S., Stevens, P. S., and Jathar, S. H.: Data associated with "Simulating secondary organic aerosol in a regional air quality model using the statistical oxidation model - Part 3: Assessing the influence of semi-volatile and intermediate-volatility organic compounds and NO ${ }_{x}$, https://doi.org/10.25675/10217/194377, 2019.

American Lung Association: State of the Air 2017, available at: https://www.lung.org/local-content/california/our-initiatives/ state-of-the-air/2017/state-of-the-air-2017.html (last access: 19 April 2017), 2017.

Baker, K. R., Carlton, A. G., Kleindienst, T. E., Offenberg, J. H., Beaver, M. R., Gentner, D. R., Goldstein, A. H., Hayes, P. L., Jimenez, J. L., Gilman, J. B., de Gouw, J. A., Woody, M. C., Pye, H. O. T., Kelly, J. T., Lewandowski, M., Jaoui, M., Stevens, P. S., Brune, W. H., Lin, Y.-H., Rubitschun, C. L., and Surratt, J. D.: Gas and aerosol carbon in California: comparison of measurements and model predictions in Pasadena and Bakersfield, At- mos. Chem. Phys., 15, 5243-5258, https://doi.org/10.5194/acp15-5243-2015, 2015.

Bergström, R., Denier van der Gon, H. A. C., Prévôt, A. S. H., Yttri, K. E., and Simpson, D.: Modelling of organic aerosols over Europe (2002-2007) using a volatility basis set (VBS) framework: application of different assumptions regarding the formation of secondary organic aerosol, Atmos. Chem. Phys., 12, 8499-8527, https://doi.org/10.5194/acp-12-8499-2012, 2012.

Bond, T. C., Streets, D. G., Yarber, K. F., Nelson, S. M., Woo, J.-H., and Klimont, Z.: A technology-based global inventory of black and organic carbon emissions from combustion, J. Geophys. Res., 109, D14203, https://doi.org/10.1029/2003JD003697, 2004.

Borbon, A., Gilman, J. B., Kuster, W. C., Grand, N., Chevaillier, S., Colomb, A., Dolgorouky, C., Gros, V., Lopez, M., Sarda-Esteve, R., Holloway, J., Stutz, J., Petetin, H., McKeen, S., Beekmann, M., Warneke, C., Parrish, D. D., de Gouw, J. A.: Emission ratios of anthropogenic volatile organic compounds in northern midlatitude megacities: Observations versus emission inventories in Los Angeles and Paris, J. Geophys. Res.-Atmos., 118, 20412057, 2013.

Brandenberger, S., Mohr, M., Grob, K., and Neukom, H. P.: Contribution of unburned lubricating oil and diesel fuel to particulate emission from passenger cars, Atmos. Environ., 39, 6985-6994, 2005.

Camredon, M., Aumont, B., Lee-Taylor, J., and Madronich, S.: The SOA/VOC/NO $\mathrm{N}_{x}$ system: an explicit model of secondary organic aerosol formation, Atmos. Chem. Phys., 7, 5599-5610, https://doi.org/10.5194/acp-7-5599-2007, 2007.

Canagaratna, M. R., Jimenez, J. L., Kroll, J. H., Chen, Q., Kessler, S. H., Massoli, P., Hildebrandt Ruiz, L., Fortner, E., Williams, L. R., Wilson, K. R., Surratt, J. D., Donahue, N. M., Jayne, J. T., and Worsnop, D. R.: Elemental ratio measurements of organic compounds using aerosol mass spectrometry: characterization, improved calibration, and implications, Atmos. Chem. Phys., 15, 253-272, https://doi.org/10.5194/acp-15-253-2015, 2015.

Cappa, C. D. and Wilson, K. R.: Multi-generation gas-phase oxidation, equilibrium partitioning, and the formation and evolution of secondary organic aerosol, Atmos. Chem. Phys., 12, 9505-9528, https://doi.org/10.5194/acp-12-9505-2012, 2012.

Cappa, C. D., Zhang, X., Loza, C. L., Craven, J. S., Yee, L. D., and Seinfeld, J. H.: Application of the Statistical Oxidation Model (SOM) to Secondary Organic Aerosol formation from photooxidation of $\mathrm{C}^{12}$ alkanes, Atmos. Chem. Phys., 13, 1591-1606, https://doi.org/10.5194/acp-13-1591-2013, 2013.

Cappa, C. D., Jathar, S. H., Kleeman, M. J., Docherty, K. S., Jimenez, J. L., Seinfeld, J. H., and Wexler, A. S.: Simulating secondary organic aerosol in a regional air quality model using the statistical oxidation model - Part 2: Assessing the influence of vapor wall losses, Atmos. Chem. Phys., 16, 3041-3059, https://doi.org/10.5194/acp-16-3041-2016, 2016.

Caravaggio, G. A., Charland, J.-P., Macdonald, P., and Graham, L.: n-alkane profiles of engine lubricating oil and particulate matter by molecular sieve extraction, Environ. Sci. Technol., 41, 36973701, 2007.

Carlton, A. G., Bhave, P. V., Napelenok, S. L., Edney, E. O., Sarwar, G., Pinder, R. W., Pouliot, G. A., and Houyoux, M.: Model representation of secondary organic aerosol in CMAQv4.7, Environ. Sci. Technol., 44, 8553-8560, 2010. 
Carter, W. P. L.: Development of the SAPRC-07 chemical mechanism, Atmos. Environ., 44, 5324-5335, 2010.

Chacon-Madrid, H. J. and Donahue, N. M.: Fragmentation vs. functionalization: chemical aging and organic aerosol formation, Atmos. Chem. Phys., 11, 10553-10563, https://doi.org/10.5194/acp-11-10553-2011, 2011.

Chan, A. W. H., Kautzman, K. E., Chhabra, P. S., Surratt, J. D., Chan, M. N., Crounse, J. D., Kürten, A., Wennberg, P. O., Flagan, R. C., and Seinfeld, J. H.: Secondary organic aerosol formation from photooxidation of naphthalene and alkylnaphthalenes: implications for oxidation of intermediate volatility organic compounds (IVOCs), Atmos. Chem. Phys., 9, 3049-3060, https://doi.org/10.5194/acp-9-3049-2009, 2009.

Chhabra, P. S., Flagan, R. C., and Seinfeld, J. H.: Elemental analysis of chamber organic aerosol using an aerodyne high-resolution aerosol mass spectrometer, Atmos. Chem. Phys., 10, 4111-4131, https://doi.org/10.5194/acp-10-4111-2010, 2010.

Chhabra, P. S., Ng, N. L., Canagaratna, M. R., Corrigan, A. L., Russell, L. M., Worsnop, D. R., Flagan, R. C., and Seinfeld, J. H.: Elemental composition and oxidation of chamber organic aerosol, Atmos. Chem. Phys., 11, 8827-8845, https://doi.org/10.5194/acp-11-8827-2011, 2011.

Docherty, K. S., Stone, E. A., Ulbrich, I. M., DeCarlo, P. F., Snyder, D. C., Schauer, J. J., Peltier, R. E., Weber, R. J., Murphy, S. M., Seinfeld, J. H., Grover, B. D., Eatough, D. J., and Jimenez, J. L.: Apportionment of primary and secondary organic aerosols in southern California during the 2005 study of organic aerosols in riverside (SOAR-1), Environ. Sci. Technol., 42, 7655-7662, 2008.

Docherty, K. S., Aiken, A. C., Huffman, J. A., Ulbrich, I. M., DeCarlo, P. F., Sueper, D., Worsnop, D. R., Snyder, D. C., Peltier, R. E., Weber, R. J., Grover, B. D., Eatough, D. J., Williams, B. J., Goldstein, A. H., Ziemann, P. J., and Jimenez, J. L.: The 2005 Study of Organic Aerosols at Riverside (SOAR-1): instrumental intercomparisons and fine particle composition, Atmos. Chem. Phys., 11, 12387-12420, https://doi.org/10.5194/acp-11-123872011, 2011.

Dzepina, K., Volkamer, R. M., Madronich, S., Tulet, P., Ulbrich, I. M., Zhang, Q., Cappa, C. D., Ziemann, P. J., and Jimenez, J. L.: Evaluation of recently-proposed secondary organic aerosol models for a case study in Mexico City, Atmos. Chem. Phys., 9, 5681-5709, https://doi.org/10.5194/acp-9-5681-2009, 2009.

Dzepina, K., Cappa, C. D., Volkamer, R. M., Madronich, S., Decarlo, P. F., Zaveri, R. A., and Jimenez, J. L.: Modeling the multiday evolution and aging of secondary organic aerosol during MILAGRO 2006, Environ. Sci. Technol., 45, 3496-3503, 2011.

Ehn, M., Thornton, J. A., Kleist, E., Sipilä, M., Junninen, H., Pullinen, I., Springer, M., Rubach, F., Tillmann, R., Lee, B., LopezHilfiker, F., Andres, S., Acir, I.-H., Rissanen, M., Jokinen, T., Schobesberger, S., Kangasluoma, J., Kontkanen, J., Nieminen, T., Kurtén, T., Nielsen, L. B., Jørgensen, S., Kjaergaard, H. G., Canagaratna, M., Maso, M. D., Berndt, T., Petäjä, T., Wahner, A., Kerminen, V.-M., Kulmala, M., Worsnop, D. R., Wildt, J., and Mentel, T. F.: A large source of low-volatility secondary organic aerosol, Nature, 506, 476-479, 2014.

Eluri, S., Cappa, C. D., Friedman, B., Farmer, D. K., and Jathar, S. H.: Modeling the formation and composition of secondary organic aerosol from diesel exhaust using parameterized and semiexplicit chemistry and thermodynamic models, Atmos. Chem.
Phys., 18, 13813-13838, https://doi.org/10.5194/acp-18-138132018, 2018.

Emmons, L. K., Walters, S., Hess, P. G., Lamarque, J.-F., Pfister, G. G., Fillmore, D., Granier, C., Guenther, A., Kinnison, D., Laepple, T., Orlando, J., Tie, X., Tyndall, G., Wiedinmyer, C., Baughcum, S. L., and Kloster, S.: Description and evaluation of the Model for Ozone and Related chemical Tracers, version 4 (MOZART-4), Geosci. Model Dev., 3, 43-67, https://doi.org/10.5194/gmd-3-43-2010, 2010.

Ensberg, J. J., Hayes, P. L., Jimenez, J. L., Gilman, J. B., Kuster, W. C., de Gouw, J. A., Holloway, J. S., Gordon, T. D., Jathar, S., Robinson, A. L., and Seinfeld, J. H.: Emission factor ratios, SOA mass yields, and the impact of vehicular emissions on SOA formation, Atmos. Chem. Phys., 14, 2383-2397, https://doi.org/10.5194/acp-14-2383-2014, 2014.

Fountoukis, C., Megaritis, A. G., Skyllakou, K., Charalampidis, P. E., Denier van der Gon, H. A. C., Crippa, M., Prévôt, A. S. H., Fachinger, F., Wiedensohler, A., Pilinis, C., and Pandis, S. N.: Simulating the formation of carbonaceous aerosol in a European Megacity (Paris) during the MEGAPOLI summer and winter campaigns, Atmos. Chem. Phys., 16, 3727-3741, https://doi.org/10.5194/acp-16-3727-2016, 2016.

Fujita, E. M., Campbell, D. E., Stockwell, W. R., Saunders, E., Fitzgerald, R., and Perea, R.: Projected ozone trends and changes in the ozone-precursor relationship in the South Coast Air Basin in response to varying reductions of precursor emissions, J. Air Waste Manage. Assoc., 66, 201-214, 2016.

Fuzzi, S., Baltensperger, U., Carslaw, K., Decesari, S., Denier van der Gon, H., Facchini, M. C., Fowler, D., Koren, I., Langford, B., Lohmann, U., Nemitz, E., Pandis, S., Riipinen, I., Rudich, Y., Schaap, M., Slowik, J. G., Spracklen, D. V., Vignati, E., Wild, M., Williams, M., and Gilardoni, S.: Particulate matter, air quality and climate: lessons learned and future needs, Atmos. Chem. Phys., 15, 8217-8299, https://doi.org/10.5194/acp15-8217-2015, 2015.

Gentner, D. R., Isaacman, G., Worton, D. R., Chan, A. W. H., Dallmann, T. R., Davis, L., Liu, S., Day, D. A., Russell, L. M., Wilson, K. R., Weber, R., Guha, A., Harley, R. A., and Goldstein, A. H.: Elucidating secondary organic aerosol from diesel and gasoline vehicles through detailed characterization of organic carbon emissions, P. Natl. Acad. Sci. USA, 109, 18318-18323, 2012.

Gentner, D. R., Jathar, S. H., Gordon, T. D., Bahreini, R., Day, D. A., El Haddad, I., Hayes, P. L., Pieber, S. M., Platt, S. M., de Gouw, J., Goldstein, A. H., Harley, R. A., Jimenez, J. L., Prévôt, A. S. H., and Robinson, A. L.: Review of Urban Secondary Organic Aerosol Formation from Gasoline and Diesel Motor Vehicle Emissions, Environ. Sci. Technol., 51, 1074-1093, 2017.

Gong, S. L.: A parameterization of sea-salt aerosol source function for sub-and super-micron particles, Global Biogeochem. Cy., 17, 1097, https://doi.org/10.1029/2003GB002079, 2003.

Gordon, T. D., Presto, A. A., May, A. A., Nguyen, N. T., Lipsky, E. M., Donahue, N. M., Gutierrez, A., Zhang, M., Maddox, C., Rieger, P., Chattopadhyay, S., Maldonado, H., Maricq, M. M., and Robinson, A. L.: Secondary organic aerosol formation exceeds primary particulate matter emissions for lightduty gasoline vehicles, Atmos. Chem. Phys., 14, 4661-4678, https://doi.org/10.5194/acp-14-4661-2014, 2014a.

Gordon, T. D., Presto, A. A., Nguyen, N. T., Robertson, W. H., Na, K., Sahay, K. N., Zhang, M., Maddox, C., Rieger, 
P., Chattopadhyay, S., Maldonado, H., Maricq, M. M., and Robinson, A. L.: Secondary organic aerosol production from diesel vehicle exhaust: impact of aftertreatment, fuel chemistry and driving cycle, Atmos. Chem. Phys., 14, 4643-4659, https://doi.org/10.5194/acp-14-4643-2014, 2014b.

Grieshop, A. P., Logue, J. M., Donahue, N. M., and Robinson, A. L.: Laboratory investigation of photochemical oxidation of organic aerosol from wood fires 1: measurement and simulation of organic aerosol evolution, Atmos. Chem. Phys., 9, 1263-1277, https://doi.org/10.5194/acp-9-1263-2009, 2009a.

Grieshop, A. P., Donahue, N. M., and Robinson, A. L.: Laboratory investigation of photochemical oxidation of organic aerosol from wood fires 2: analysis of aerosol mass spectrometer data, Atmos. Chem. Phys., 9, 2227-2240, https://doi.org/10.5194/acp-9-22272009, 2009b.

Griffith, S. M., Hansen, R. F., Dusanter, S., Michoud, V., Gilman, J. B., Kuster, W. C., Veres, P. R., Graus, M., de Gouw, J. A., Roberts, J., Young, C., Washenfelder, R., Brown, S. S., Thalman, R., Waxman, E., Volkamer, R., Tsai, C., Stutz, J., Flynn, J. H., Grossberg, N., Lefer, B., Alvarez, S. L., Rappenglueck, B., Mielke, L. H., Osthoff, H. D., and Stevens, P. S.: Measurements of hydroxyl and hydroperoxy radicals during CalNex-LA: Model comparisons and radical budgets, J. Geophys. Res.-Atmos., 121, 4211-4232, 2016.

Guenther, A., Karl, T., Harley, P., Wiedinmyer, C., Palmer, P. I., and Geron, C.: Estimates of global terrestrial isoprene emissions using MEGAN (Model of Emissions of Gases and Aerosols from Nature), Atmos. Chem. Phys., 6, 3181-3210, https://doi.org/10.5194/acp-6-3181-2006, 2006.

Hatch, L. E., Luo, W., Pankow, J. F., Yokelson, R. J., Stockwell, C. E., and Barsanti, K. C.: Identification and quantification of gaseous organic compounds emitted from biomass burning using two-dimensional gas chromatography-time-offlight mass spectrometry, Atmos. Chem. Phys., 15, 1865-1899, https://doi.org/10.5194/acp-15-1865-2015, 2015.

Hayes, P. L., Ortega, A. M., Cubison, M. J., Froyd, K. D., Zhao, Y., Cliff, S. S., Hu, W. W., Toohey, D. W., Flynn, J. H., Lefer, B. L., Grossberg, N., Alvarez, S., Rappenglück, B., Taylor, J. W., Allan, J. D., Holloway, J. S., Gilman, J. B., Kuster, W. C., de Gouw, J. A., Massoli, P., Zhang, X., Liu, J., Weber, R. J., Corrigan, A. L., Russell, L. M., Isaacman, G., Worton, D. R., Kreisberg, N. M., Goldstein, A. H., Thalman, R., Waxman, E. M., Volkamer, R., Lin, Y. H., Surratt, J. D., Kleindienst, T. E., Offenberg, J. H., Dusanter, S., Griffith, S., Stevens, P. S., Brioude, J., Angevine, W. M., and Jimenez, J. L.: Organic aerosol composition and sources in Pasadena, California, during the 2010 CalNex campaign, J. Geophys. Res.-Atmos., 118, 9233-9257, 2013.

Hayes, P. L., Carlton, A. G., Baker, K. R., Ahmadov, R., Washenfelder, R. A., Alvarez, S., Rappenglück, B., Gilman, J. B., Kuster, W. C., de Gouw, J. A., Zotter, P., Prévôt, A. S. H., Szidat, S., Kleindienst, T. E., Offenberg, J. H., Ma, P. K., and Jimenez, J. L.: Modeling the formation and aging of secondary organic aerosols in Los Angeles during CalNex 2010, Atmos. Chem. Phys., 15, 5773-5801, https://doi.org/10.5194/acp-15-5773-2015, 2015.

Hays, M. D., Preston, W., George, B. J., George, I. J., Snow, R., Faircloth, J., Long, T., Baldauf, R. W., and McDonald, J.: Temperature and Driving Cycle Significantly Affect Carbonaceous Gas and Particle Matter Emissions from Diesel Trucks, Energy Fuels, 31, 11034-11042, 2017.
Hennigan, C. J., Miracolo, M. A., Engelhart, G. J., May, A. A., Presto, A. A., Lee, T., Sullivan, A. P., McMeeking, G. R., Coe, H., Wold, C. E., Hao, W.-M., Gilman, J. B., Kuster, W. C., de Gouw, J., Schichtel, B. A., Collett Jr., J. L., Kreidenweis, S. M., and Robinson, A. L.: Chemical and physical transformations of organic aerosol from the photo-oxidation of open biomass burning emissions in an environmental chamber, Atmos. Chem. Phys., 11, 7669-7686, https://doi.org/10.5194/acp11-7669-2011, 2011.

Henze, D. K., Seinfeld, J. H., Ng, N. L., Kroll, J. H., Fu, T.-M., Jacob, D. J., and Heald, C. L.: Global modeling of secondary organic aerosol formation from aromatic hydrocarbons: highvs. low-yield pathways, Atmos. Chem. Phys., 8, 2405-2420, https://doi.org/10.5194/acp-8-2405-2008, 2008.

Heo, J., de Foy, B., Olson, M. R., Pakbin, P., Sioutas, C., and Schauer, J. J.: Impact of regional transport on the anthropogenic and biogenic secondary organic aerosols in the Los Angeles Basin, Atmos. Environ., 103, 171-179, 2015.

Hodzic, A. and Jimenez, J. L.: Modeling anthropogenically controlled secondary organic aerosols in a megacity: a simplified framework for global and climate models, Geosci. Model Dev., 4, 901-917, https://doi.org/10.5194/gmd-4-901-2011, 2011.

Hodzic, A., Kasibhatla, P. S., Jo, D. S., Cappa, C. D., Jimenez, J. L., Madronich, S., and Park, R. J.: Rethinking the global secondary organic aerosol (SOA) budget: stronger production, faster removal, shorter lifetime, Atmos. Chem. Phys., 16, 7917-7941, https://doi.org/10.5194/acp-16-7917-2016, 2016.

Hofzumahaus, A., Rohrer, F., Lu, K., Bohn, B., Brauers, T., Chang, C.-C., Fuchs, H., Holland, F., Kita, K., Kondo, Y., Li, X., Lou, S., Shao, M., Zeng, L., Wahner, A., and Zhang, Y.: Amplified trace gas removal in the troposphere, Science, 324, 1702-1704, 2009.

Huang, Y., Zhao, R., Charan, S. M., Kenseth, C. M., Zhang, X., and Seinfeld, J. H.: Unified Theory of Vapor-Wall Mass Transport in Teflon-Walled Environmental Chambers, Environ. Sci. Technol., 52, 2134-2142, 2018.

Huffman, J. A., Docherty, K. S., Aiken, A. C., Cubison, M. J., U1brich, I. M., DeCarlo, P. F., Sueper, D., Jayne, J. T., Worsnop, D. R., Ziemann, P. J., and Jimenez, J. L.: Chemically-resolved aerosol volatility measurements from two megacity field studies, Atmos. Chem. Phys., 9, 7161-7182, https://doi.org/10.5194/acp9-7161-2009, 2009.

Hu, J., Zhang, H., Chen, S., Ying, Q., Wiedinmyer, C., Vandenberghe, F., and Kleeman, M. J.: Identifying $\mathrm{PM}_{2.5}$ and $\mathrm{PM}_{0} .1$ sources for epidemiological studies in California, Environ. Sci. Technol., 48, 4980-4990, 2014.

Hu, J., Zhang, H., Ying, Q., Chen, S.-H., Vandenberghe, F., and Kleeman, M. J.: Long-term particulate matter modeling for health effect studies in California - Part 1: Model performance on temporal and spatial variations, Atmos. Chem. Phys., 15, 34453461, https://doi.org/10.5194/acp-15-3445-2015, 2015.

Jacob, D.: Introduction to Atmospheric Chemistry, Princeton University Press, Princeton, New Jersey, 1999.

Jathar, S. H., Gordon, T. D., Hennigan, C. J., Pye, H. O. T., Pouliot, G., Adams, P. J., Donahue, N. M., and Robinson, A. L.: Unspeciated organic emissions from combustion sources and their influence on the secondary organic aerosol budget in the United States, P. Natl. Acad. Sci. USA, 111, 10473-10478, 2014.

Jathar, S. H., Cappa, C. D., Wexler, A. S., Seinfeld, J. H., and Kleeman, M. J.: Multi-generational oxidation model to simulate sec- 
ondary organic aerosol in a 3-D air quality model, Geosci. Model Dev., 8, 2553-2567, https://doi.org/10.5194/gmd-8-2553-2015, 2015.

Jathar, S. H., Cappa, C. D., Wexler, A. S., Seinfeld, J. H., and Kleeman, M. J.: Simulating secondary organic aerosol in a regional air quality model using the statistical oxidation model - Part 1: Assessing the influence of constrained multi-generational ageing, Atmos. Chem. Phys., 16, 2309-2322, https://doi.org/10.5194/acp-16-2309-2016, 2016.

Jathar, S. H., Woody, M., Pye, H. O. T., Baker, K. R., and Robinson, A. L.: Chemical transport model simulations of organic aerosol in southern California: model evaluation and gasoline and diesel source contributions, Atmos. Chem. Phys., 17, 43054318, https://doi.org/10.5194/acp-17-4305-2017, 2017a.

Jathar, S. H., Heppding, C., Link, M. F., Farmer, D. K., Akherati, A., Kleeman, M. J., de Gouw, J. A., Veres, P. R., and Roberts, J. M.: Investigating diesel engines as an atmospheric source of isocyanic acid in urban areas, Atmos. Chem. Phys., 17, 89598970, https://doi.org/10.5194/acp-17-8959-2017, 2017 b.

Jimenez, J. L., Canagaratna, M. R., Donahue, N. M., Prevot, A. S. H., Zhang, Q., Kroll, J. H., DeCarlo, P. F., Allan, J. D., Coe, H., Ng, N. L., Aiken, A. C., Docherty, K. S., Ulbrich, I. M., Grieshop, A. P., Robinson, A. L., Duplissy, J., Smith, J. D., Wilson, K. R., Lanz, V. A., Hueglin, C., Sun, Y. L., Tian, J., Laaksonen, A., Raatikainen, T., Rautiainen, J., Vaattovaara, P., Ehn, M., Kulmala, M., Tomlinson, J. M., Collins, D. R., Cubison, M. J., Dunlea, E. J., Huffman, J. A., Onasch, T. B., Alfarra, M. R., Williams, P. I., Bower, K., Kondo, Y., Schneider, J., Drewnick, F., Borrmann, S., Weimer, S., Demerjian, K., Salcedo, D., Cottrell, L., Griffin, R., Takami, A., Miyoshi, T., Hatakeyama, S., Shimono, A., Sun, J. Y., Zhang, Y. M., Dzepina, K., Kimmel, J. R., Sueper, D., Jayne, J. T., Herndon, S. C., Trimborn, A. M., Williams, L. R., Wood, E. C., Middlebrook, A. M., Kolb, C. E., Baltensperger, U., and Worsnop, D. R.: Evolution of organic aerosols in the atmosphere, Science, 326, 1525-1529, 2009.

Kaltsonoudis, C., Kostenidou, E., Louvaris, E., Psichoudaki, M., Tsiligiannis, E., Florou, K., Liangou, A., and Pandis, S. N.: Characterization of fresh and aged organic aerosol emissions from meat charbroiling, Atmos. Chem. Phys., 17, 7143-7155, https://doi.org/10.5194/acp-17-7143-2017, 2017.

Kim, P. S., Jacob, D. J., Fisher, J. A., Travis, K., Yu, K., Zhu, L., Yantosca, R. M., Sulprizio, M. P., Jimenez, J. L., CampuzanoJost, P., Froyd, K. D., Liao, J., Hair, J. W., Fenn, M. A., Butler, C. F., Wagner, N. L., Gordon, T. D., Welti, A., Wennberg, P. O., Crounse, J. D., St. Clair, J. M., Teng, A. P., Millet, D. B., Schwarz, J. P., Markovic, M. Z., and Perring, A. E.: Sources, seasonality, and trends of southeast US aerosol: an integrated analysis of surface, aircraft, and satellite observations with the GEOS-Chem chemical transport model, Atmos. Chem. Phys., 15, 10411-10433, https://doi.org/10.5194/acp-15-104112015, 2015.

Kleeman, M. J. and Cas, G. R.: A 3D Eulerian source-oriented model for an externally mixed aerosol, Environ. Sci. Technol., 35, 4834-4848, 2001.

Kleeman, M. J., Ying, Q., Lu, J., Mysliwiec, M. J., Griffin, R. J., Chen, J., and Clegg, S.: Source apportionment of secondary organic aerosol during a severe photochemical smog episode, Atmos. Environ., 41, 576-591, 2007.
Koo, B., Knipping, E., and Yarwood, G.: 1.5-Dimensional volatility basis set approach for modeling organic aerosol in CAMx and CMAQ, Atmos. Environ., 95, 158-164, 2014.

Koss, A. R., Sekimoto, K., Gilman, J. B., Selimovic, V., Coggon, M. M., Zarzana, K. J., Yuan, B., Lerner, B. M., Brown, S. S., Jimenez, J. L., Krechmer, J., Roberts, J. M., Warneke, C., Yokelson, R. J., and de Gouw, J.: Non-methane organic gas emissions from biomass burning: identification, quantification, and emission factors from PTR-ToF during the FIREX 2016 laboratory experiment, Atmos. Chem. Phys., 18, 3299-3319, https://doi.org/10.5194/acp-18-3299-2018, 2018.

Krechmer, J. E., Pagonis, D., Ziemann, P. J., and Jimenez, J. L.: Quantification of Gas-Wall Partitioning in Teflon Environmental Chambers Using Rapid Bursts of Low-Volatility Oxidized Species Generated in Situ, Environ. Sci. Technol., 50, 57575765, 2016.

Kroll, J. H. and Seinfeld, J. H.: Chemistry of secondary organic aerosol: Formation and evolution of low-volatility organics in the atmosphere, Atmos. Environ., 42, 3593-3624, 2008.

Kroll, J. H., Smith, J. D., Che, D. L., Kessler, S. H., Worsnop, D. R., and Wilson, K. R.: Measurement of fragmentation and functionalization pathways in the heterogeneous oxidation of oxidized organic aerosol, Phys. Chem. Chem. Phys., 11, 8005-8014, 2009.

Kuwayama, T., Collier, S., Forestieri, S., Brady, J. M., Bertram, T. H., Cappa, C. D., Zhang, Q., and Kleeman, M. J.: Volatility of Primary Organic Aerosol Emitted from Light Duty Gasoline Vehicles, Environ. Sci. Technol., 49, 1569-1577, 2015.

Lim, Y. B. and Ziemann, P. J.: Effects of Molecular Structure on Aerosol Yields from $\mathrm{OH}$ Radical-Initiated Reactions of Linear, Branched, and Cyclic Alkanes in the Presence of $\mathrm{NO}_{x}$, Environ. Sci. Technol., 43, 2328-2334, 2009.

Lipsky, E. M. and Robinson, A. L.: Effects of dilution on fine particle mass and partitioning of semivolatile organics in diesel exhaust and wood smoke, Environ. Sci. Technol., 40, 155-162, 2006.

Liu, T., Li, Z., Chan, M., and Chan, C. K.: Formation of secondary organic aerosols from gas-phase emissions of heated cooking oils, Atmos. Chem. Phys., 17, 7333-7344, https://doi.org/10.5194/acp-17-7333-2017, 2017.

Louvaris, E. E., Florou, K., Karnezi, E., Papanastasiou, D. K., Gkatzelis, G. I., and Pandis, S. N.: Volatility of source apportioned wintertime organic aerosol in the city of Athens, Atmos. Environ., 158, 138-147, 2017.

Louvaris, E. E., Karnezi, E., Kostenidou, E., Kaltsonoudis, C., and Pandis, S. N.: Estimation of the volatility distribution of organic aerosol combining thermodenuder and isothermal dilution measurements, Atmos. Meas. Tech., 10, 3909-3918, https://doi.org/10.5194/amt-10-3909-2017, 2017.

Loza, C. L., Craven, J. S., Yee, L. D., Coggon, M. M., Schwantes, R. H., Shiraiwa, M., Zhang, X., Schilling, K. A., Ng, N. L., Canagaratna, M. R., Ziemann, P. J., Flagan, R. C., and Seinfeld, J. H.: Secondary organic aerosol yields of 12-carbon alkanes, Atmos. Chem. Phys., 14, 1423-1439, https://doi.org/10.5194/acp14-1423-2014, 2014.

Ma, P. K., Zhao, Y., Robinson, A. L., Worton, D. R., Goldstein, A. H., Ortega, A. M., Jimenez, J. L., Zotter, P., Prévôt, A. S. H., Szidat, S., and Hayes, P. L.: Evaluating the impact of new observational constraints on P-S/IVOC emissions, multigeneration oxidation, and chamber wall losses on SOA model- 
ing for Los Angeles, CA, Atmos. Chem. Phys., 17, 9237-9259, https://doi.org/10.5194/acp-17-9237-2017, 2017.

May, A. A., Presto, A. A., Hennigan, C. J., Nguyen, N. T., Gordon, T. D., and Robinson, A. L.: Gas-particle partitioning of primary organic aerosol emissions: (1) Gasoline vehicle exhaust, Atmos. Environ., 77, 128-139, 2013a.

May, A. A., Presto, A. A., Hennigan, C. J., Nguyen, N. T., Gordon, T. D., and Robinson, A. L.: Gas-particle partitioning of primary organic aerosol emissions: (2) diesel vehicles, Environ. Sci. Technol., 47, 8288-8296, 2013b.

May, A. A., Levin, E. J. T., Hennigan, C. J., Riipinen, I., Lee, T., Collett, J. L., Jimenez, J. L., Kreidenweis, S. M., and Robinson, A. L.: Gas-particle partitioning of primary organic aerosol emissions: 3. Biomass burning, J. Geophys. Res.-Atmos., 118, 11327-11338, https://doi.org/10.1002/jgrd.50828, 2013c.

May, A. A., Nguyen, N. T., Presto, A. A., Gordon, T. D., Lipsky, E. M., Karve, M., Gutierrez, A., Robertson, W. H., Zhang, M., Brandow, C., Chang, O., Chen, S., Cicero-Fernandez, P., Dinkins, L., Fuentes, M., Huang, S.-M., Ling, R., Long, J., Maddox, C., Massetti, J., McCauley, E., Miguel, A., Na, K., Ong, R., Pang, Y., Rieger, P., Sax, T., Truong, T., Vo, T., Chattopadhyay, S., Maldonado, H., Maricq, M. M., and Robinson, A. L.: Gas- and particle-phase primary emissions from in-use, on-road gasoline and diesel vehicles, Atmos. Environ., 88, 247-260, 2014.

McDonald, B. C., Gentner, D. R., Goldstein, A. H., and Harley, R. A.: Long-term trends in motor vehicle emissions in US urban areas, Environ. Sci. Technol., 47, 10022-10031, 2013.

McDonald, B. C., de Gouw, J. A., Gilman, J. B., Jathar, S. H., Akherati, A., Cappa, C. D., Jimenez, J. L., Lee-Taylor, J., Hayes, P. L., McKeen, S. A., Cui, Y. Y., Kim, S.-W., Gentner, D. R., Isaacman-VanWertz, G., Goldstein, A. H., Harley, R. A., Frost, G. J., Roberts, J. M., Ryerson, T. B., and Trainer, M.: Volatile chemical products emerging as largest petrochemical source of urban organic emissions, Science, 359, 760-764, 2018.

Miracolo, M. A., Presto, A. A., Lambe, A. T., Hennigan, C. J., Donahue, N. M., Kroll, J. H., Worsnop, D. R., and Robinson, A. L.: Photo-Oxidation of Low-Volatility Organics Found in Motor Vehicle Emissions: Production and Chemical Evolution of Organic Aerosol Mass, Environ. Sci. Technol., 44, 1638-1643, 2010.

Murphy, B. N. and Pandis, S. N.: Simulating the formation of semivolatile primary and secondary organic aerosol in a regional chemical transport model, Environ. Sci. Technol., 43, 47224728, 2009.

Murphy, B. N., Donahue, N. M., Robinson, A. L., and Pandis, S. N.: A naming convention for atmospheric organic aerosol, Atmos. Chem. Phys., 14, 5825-5839, https://doi.org/10.5194/acp14-5825-2014, 2014.

Murphy, B. N., Woody, M. C., Jimenez, J. L., Carlton, A. M. G., Hayes, P. L., Liu, S., Ng, N. L., Russell, L. M., Setyan, A., Xu, L., Young, J., Zaveri, R. A., Zhang, Q., and Pye, H. O. T.: Semivolatile POA and parameterized total combustion SOA in CMAQv5.2: impacts on source strength and partitioning, Atmos. Chem. Phys., 17, 11107-11133, https://doi.org/10.5194/acp-1711107-2017, 2017.

Ng, N. L., Kroll, J. H., Chan, A. W. H., Chhabra, P. S., Flagan, R. C., and Seinfeld, J. H.: Secondary organic aerosol formation from m-xylene, toluene, and benzene, Atmos. Chem. Phys., 7, 3909-3922, https://doi.org/10.5194/acp-7-3909-2007, 2007a.
Ng, N. L., Chhabra, P. S., Chan, A. W. H., Surratt, J. D., Kroll, J. H., Kwan, A. J., McCabe, D. C., Wennberg, P. O., Sorooshian, A., Murphy, S. M., Dalleska, N. F., Flagan, R. C., and Seinfeld, J. H.: Effect of $\mathrm{NO}_{x}$ level on secondary organic aerosol (SOA) formation from the photooxidation of terpenes, Atmos. Chem. Phys. 7, 5159-5174, https://doi.org/10.5194/acp-7-5159-2007, $2007 \mathrm{~b}$.

Pachauri, R. K., Allen, M. R., Barros, V. R., Broome, J., Cramer, W., Christ, R., Church, J. A., Clarke, L., Dahe, Q., Dasgupta, P., Dubash, N. K., Edenhofer, O., Elgizouli, I., Field, C. B., Forster, P., Friedlingstein, P., Fuglestvedt, J., Gomez-Echeverri, L., Hallegatte, S., Hegerl, G., Howden, M., Jiang, K., Jimenez Cisneroz, B., Kattsov, V., Lee, H., Mach, K. J., Marotzke, J., Mastrandrea, M. D., Meyer, L., Minx, J., Mulugetta, Y., O’Brien, K., Oppenheimer, M., Pereira, J. J., Pichs-Madruga, R., Plattner, G.-K., Pörtner, H.-O., Power, S. B., Preston, B., Ravindranath, N. H., Reisinger, A., Riahi, K., Rusticucci, M., Scholes, R., Seyboth, K., Sokona, Y., Stavins, R., Stocker, T. F., Tschakert, P., van Vuuren, D., and van Ypserle, J.-P.: Climate Change 2014: Synthesis Report, Contribution of Working Groups I, II and III to the Fifth Assessment Report of the Intergovernmental Panel on Climate Change, edited by: Pachauri, R. K. and Meyer, L., IPCC, Geneva, Switzerland, 2014.

Pagonis, D., Krechmer, J. E., de Gouw, J., Jimenez, J. L., and Ziemann, P. J.: Effects of gas-wall partitioning in Teflon tubing and instrumentation on time-resolved measurements of gasphase organic compounds, Atmos. Meas. Tech., 10, 4687-4696, https://doi.org/10.5194/amt-10-4687-2017, 2017.

Praske, E., Otkjær, R. V., Crounse, J. D., Hethcox, J. C., Stoltz, B. M., Kjaergaard, H. G., and Wennberg, P. O.: Atmospheric autoxidation is increasingly important in urban and suburban North America, P. Natl. Acad. Sci. USA, 115, 64-69, 2018.

Presto, A. A., Miracolo, M. A., Donahue, N. M., and Robinson, A. L.: Secondary Organic Aerosol Formation from High-NOx Photo-Oxidation of Low Volatility Precursors: n-Alkanes, Environ. Sci. Technol., 44, 2029-2034, 2010.

Presto, A. A. and Donahue, N. M.: Investigation of $\alpha$-pinene+ ozone secondary organic aerosol formation at low total aerosol mass, Environ. Sci. Technol., 40, 3536-3543, 2006.

Pye, H. O. T. and Pouliot, G. A.: Modeling the role of alkanes, polycyclic aromatic hydrocarbons, and their oligomers in secondary organic aerosol formation, Environ. Sci. Technol., 46, 6041-6047, 2012.

Pye, H. O. T. and Seinfeld, J. H.: A global perspective on aerosol from low-volatility organic compounds, Atmos. Chem. Phys., 10, 4377-4401, https://doi.org/10.5194/acp-10-4377-2010, 2010.

Robinson, A. L., Donahue, N. M., Shrivastava, M. K., Weitkamp, E. A., Sage, A. M., Grieshop, A. P., Lane, T. E., Pierce, J. R., and Pandis, S. N.: Rethinking organic aerosols: semivolatile emissions and photochemical aging, Science, 315, 1259-1262, 2007.

Robinson, A. L., Grieshop, A. P., Donahue, N. M., and Hunt, S. W.: Updating the Conceptual Model for Fine Particle Mass Emissions from Combustion Systems, J. Air Waste Manage. Assoc., 60, 1204-1222, 2010.

Schauer, J. J., Kleeman, M. J., Cass, G. R., and Simoneit, B. R. T.: Measurement of Emissions from Air Pollution Sources, 2, $\mathrm{C}_{1}$ through $\mathrm{C}_{30}$ Organic Compounds from Medium Duty Diesel Trucks, Environ. Sci. Technol., 33, 1578-1587, 1999.

Schauer, J. J., Kleeman, M. J., Cass, G. R., and Simoneit, B. R. T.: Measurement of Emissions from Air Pollution Sources, 3, $\mathrm{C}_{1}$ - 
$\mathrm{C}_{29}$ Organic Compounds from Fireplace Combustion of Wood, Environ. Sci. Technol., 35, 1716-1728, 2001.

Schauer, J. J., Kleeman, M. J., Cass, G. R., and Simoneit, B. R. T.: Measurement of Emissions from Air Pollution Sources, 4, $\mathrm{C}_{1^{-}}$ $\mathrm{C}_{27}$ Organic Compounds from Cooking with Seed Oils, Environ. Sci. Technol., 36, 567-575, 2002a.

Schauer, J. J., Kleeman, M. J., Cass, G. R., and Simoneit, B. R. T.: Measurement of Emissions from Air Pollution Sources, 5, $\mathrm{C}_{1}$ $\mathrm{C}_{32}$ Organic Compounds from Gasoline-Powered Motor Vehicles, Environ. Sci. Technol., 36, 1169-1180, 2002b.

Shrivastava, M. K., Lane, T. E., Donahue, N. M., Pandis, S. N., and Robinson, A. L.: Effects of gas particle partitioning and aging of primary emissions on urban and regional organic aerosol concentrations, J. Geophys. Res., 113, D18301, https://doi.org/10.1029/2007JD009735, 2008.

Stockwell, C. E., Veres, P. R., Williams, J., and Yokelson, R. J.: Characterization of biomass burning emissions from cooking fires, peat, crop residue, and other fuels with high-resolution proton-transfer-reaction time-of-flight mass spectrometry, Atmos. Chem. Phys., 15, 845-865, https://doi.org/10.5194/acp-15845-2015, 2015.

Subramanian, R., Khlystov, A. Y., Cabada, J. C., and Robinson, A. L.: Positive and negative artifacts in particulate organic carbon measurements with denuded and undenuded sampler configurations special issue of aerosol science and technology on findings from the fine particulate matter supersites program, Aerosol Sci. Technol., 38, 27-48, 2004.

Sunol, A. M., Charan, S. M., and Seinfeld, J. H.: Computational simulation of the dynamics of secondary organic aerosol formation in an environmental chamber, Aerosol Sci. Technol., 52, 470-482, 2018.

Tkacik, D. S., Presto, A. A., Donahue, N. M., and Robinson, A. L.: Secondary Organic Aerosol Formation from IntermediateVolatility Organic Compounds: Cyclic, Linear, and Branched Alkanes, Environ. Sci. Technol., 46, 8773-8781, 2012.

Tkacik, D. S., Robinson, E. S., Ahern, A., Saleh, R., Stockwell, C., Veres, P., Simpson, I. J., Meinardi, S., Blake, D. R., Yokelson, R. J., Presto, A. A., Sullivan, R. C., Donahue, N. M., and Robinson, A. L.: A dual-chamber method for quantifying the effects of atmospheric perturbations on secondary organic aerosol formation from biomass burning emissions, J. Geophys. Res.-Atmos., 122, 2016JD025784, https://doi.org/10.1002/2016JD025784, 2017.

Tsimpidi, A. P., Karydis, V. A., Zavala, M., Lei, W., Molina, L., Ulbrich, I. M., Jimenez, J. L., and Pandis, S. N.: Evaluation of the volatility basis-set approach for the simulation of organic aerosol formation in the Mexico City metropolitan area, Atmos. Chem. Phys., 10, 525-546, https://doi.org/10.5194/acp-10-5252010, 2010.

Turpin, B. J. and Lim, H.-J.: Species Contributions to PM 2.5 Mass Concentrations: Revisiting Common Assumptions for Estimating Organic Mass, Aerosol Sci. Technol., 35, 602-610, 2001.

Volkamer, R., Jimenez, J. L., San Martini, F., Dzepina, K., Zhang, Q., Salcedo, D., Molina, L. T., Worsnop, D. R., and Molina, M. J.: Secondary organic aerosol formation from anthropogenic air pollution: Rapid and higher than expected, Geophys. Res. Lett., 33, L17811, https://doi.org/10.1029/2006GL026899, 2006.

Warneke, C., de Gouw, J. A., Holloway, J. S., Peischl, J., Ryerson, T. B., Atlas, E., Blake, D., Trainer, M., and Parrish, D. D.: Multiyear trends in volatile organic compounds in Los An- geles, California: Five decades of decreasing emissions: Trends in vocs in Los Angeles, J. Geophys. Res., 117, D00V17, https://doi.org/10.1029/2012JD017899, 2012.

Wiedinmyer, C., Akagi, S. K., Yokelson, R. J., Emmons, L. K., AlSaadi, J. A., Orlando, J. J., and Soja, A. J.: The Fire INventory from NCAR (FINN): a high resolution global model to estimate the emissions from open burning, Geosci. Model Dev., 4, 625641, https://doi.org/10.5194/gmd-4-625-2011, 2011.

Woody, M. C., Baker, K. R., Hayes, P. L., Jimenez, J. L., Koo, B., and Pye, H. O. T.: Understanding sources of organic aerosol during CalNex-2010 using the CMAQ-VBS, Atmos. Chem. Phys., 16, 4081-4100, https://doi.org/10.5194/acp16-4081-2016, 2016.

Worton, D. R., Isaacman, G., Gentner, D. R., Dallmann, T. R., Chan, A. W. H., Ruehl, C., Kirchstetter, T. W., Wilson, K. R., Harley, R. A., and Goldstein, A. H.: Lubricating oil dominates primary organic aerosol emissions from motor vehicles, Environ. Sci. Technol., 48, 3698-3706, 2014.

Xu, L., Guo, H., Boyd, C. M., Klein, M., Bougiatioti, A., Cerully, K. M., Hite, J. R., Isaacman-VanWertz, G., Kreisberg, N. M., Knote, C., Olson, K., Koss, A., Goldstein, A. H., Hering, S. V., de Gouw, J., Baumann, K., Lee, S.-H., Nenes, A., Weber, R. J., and Ng, N. L.: Effects of anthropogenic emissions on aerosol formation from isoprene and monoterpenes in the southeastern United States, P. Natl. Acad. Sci. USA, 112, 37-42, 2015.

Zhang, Q., Jimenez, J. L., Canagaratna, M. R., Allan, J. D., Coe, H., Ulbrich, I., Alfarra, M. R., Takami, A., Middlebrook, A. M., Sun, Y. L., and Others: Ubiquity and dominance of oxygenated species in organic aerosols in anthropogenicallyinfluenced Northern Hemisphere midlatitudes, Geophys. Res. Lett., 34, L13801, https://doi.org/10.1029/2007GL029979, 2007.

Zhang, Q. J., Beekmann, M., Drewnick, F., Freutel, F., Schneider, J., Crippa, M., Prevot, A. S. H., Baltensperger, U., Poulain, L., Wiedensohler, A., Sciare, J., Gros, V., Borbon, A., Colomb, A., Michoud, V., Doussin, J.-F., Denier van der Gon, H. A. C., Haeffelin, M., Dupont, J.-C., Siour, G., Petetin, H., Bessagnet, B., Pandis, S. N., Hodzic, A., Sanchez, O., Honoré, C., and Perrussel, O.: Formation of organic aerosol in the Paris region during the MEGAPOLI summer campaign: evaluation of the volatility-basis-set approach within the CHIMERE model, Atmos. Chem. Phys., 13, 5767-5790, https://doi.org/10.5194/acp13-5767-2013, 2013.

Zhang, Q. J., Beekmann, M., Freney, E., Sellegri, K., Pichon, J. M., Schwarzenboeck, A., Colomb, A., Bourrianne, T., Michoud, V., and Borbon, A.: Formation of secondary organic aerosol in the Paris pollution plume and its impact on surrounding regions, Atmos. Chem. Phys., 15, 13973-13992, https://doi.org/10.5194/acp-15-13973-2015, 2015.

Zhang, X., Cappa, C. D., Jathar, S. H., McVay, R. C., Ensberg, J. J., Kleeman, M. J., and Seinfeld, J. H.: Influence of vapor wall loss in laboratory chambers on yields of secondary organic aerosol, $\mathrm{P}$. Natl. Acad. Sci. USA, 111, 5802-5807, 2014.

Zhao, Y., Hennigan, C. J., May, A. A., Tkacik, D. S., de Gouw, J. A., Gilman, J. B., Kuster, W. C., Borbon, A., and Robinson, A. L.: Intermediate-Volatility Organic Compounds: A Large Source of Secondary Organic Aerosol, Environ. Sci. Technol., 48, 1374313750, 2014.

Zhao, Y., Nguyen, N. T., Presto, A. A., Hennigan, C. J., May, A. A., and Robinson, A. L.: Intermediate volatility organic compound 
emissions from on-road diesel vehicles: chemical composition, emission factors, and estimated secondary organic aerosol production, Environ. Sci. Technol., 49, 11516-11526, 2015.

Zhao, Y., Nguyen, N. T., Presto, A. A., Hennigan, C. J., May, A. A., and Robinson, A. L.: Intermediate Volatility Organic Compound Emissions from On-Road Gasoline Vehicles and Small Off-Road Gasoline Engines, Environ. Sci. Technol., 50, 4554-4563, 2016.
Zhao, Y., Saleh, R., Saliba, G., Presto, A. A., Gordon, T. D., Drozd, G. T., Goldstein, A. H., Donahue, N. M., and Robinson, A. L.: Reducing secondary organic aerosol formation from gasoline vehicle exhaust, P. Natl. Acad. Sci. USA, 114, 6984-6989, 2017. 